Nevada

Environmental

Restoration

Project

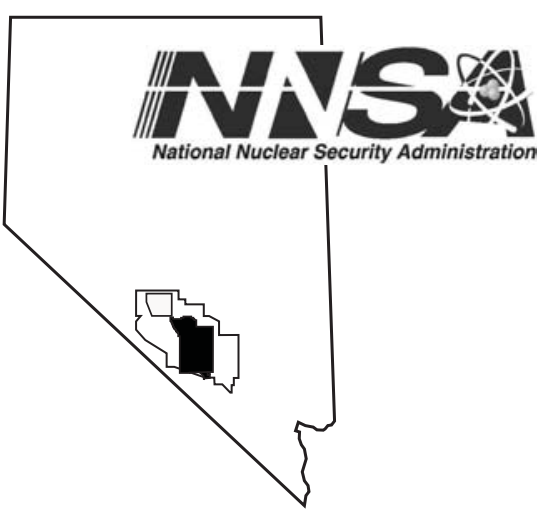

\title{
Completion Report for Well ER-8-1
}

November 2004

\section{Environmental Restoration}






\title{
DISCLAIMER STATEMENT
}

Reference herein to any specific commercial product, process, or service by trade name, trademark, manufacturer, or otherwise, does not necessarily constitute or imply its endorsement, recommendation, or favoring by the U.S. Government or any agency thereof or its contractors or subcontractors.

\section{AVAILABILITY STATEMENT}

Available for sale to the public from-

\author{
U.S. Department of Commerce \\ National Technical Information Service \\ 5285 Port Royal Road \\ Springfield, VA, 22161-0002 \\ Telephone: 800.553 .6847 \\ Fax: 703.605.6900 \\ E-mail: orders@ntis.gov \\ Online ordering: http://www.ntis.gov/ordering.htm
}

Available electronically at http://www.osti.gov/bridge.

Available for a processing fee to U.S. Department of Energy and its contractors, in paper, from-

U.S. Department of Energy

Office of Scientific and Technical Information

P.O. Box 62

Oak Ridge, TN 37831-0062

Telephone: 865.576 .8401

Fax: 865.576.5728

E-mail: reports@adonis.osti.gov 


\title{
Completion Report for Well ER-8-1
}

\author{
Prepared for: \\ U.S. Department of Energy \\ National Nuclear Security Administration \\ Nevada Site Office \\ Las Vegas, Nevada
}

Prepared by:

Bechtel Nevada

Geotechnical Sciences

Las Vegas, NV

November 2004 
This page intentionally left blank. 


\section{COMPLETION REPORT FOR WELL ER-8-1}

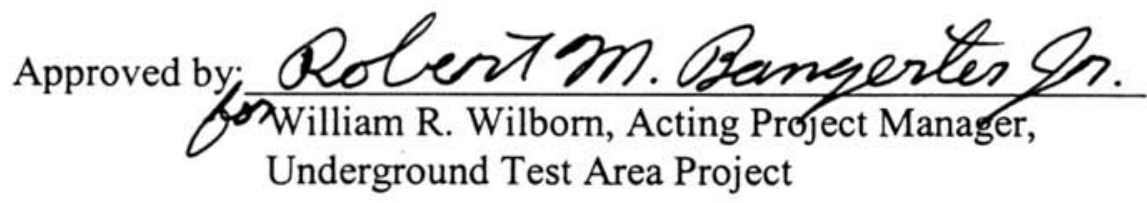

Approved by: Rolert Mn. Aengestes 7 . Environmental Restoration Division
Date: $12 / 29 / 04$

Date: $12 / 24 / 04$ 
This page intentionally left blank. 


\title{
Completion Report for Well ER-8-1 \\ DOE/NV/11718--854
}

\begin{abstract}
Well ER-8-1 was drilled for the U.S. Department of Energy, National Nuclear Security Administration Nevada Site Office in support of the Nevada Environmental Restoration Project at the Nevada Test Site, Nye County, Nevada. This well was drilled in October and November of 2002 as part of a hydrogeologic investigation program for the Yucca Flat/Climax Mine Corrective Action Unit in the northeastern portion of the Nevada Test Site. Well ER-8-1 is located at the north end of Yucca Flat approximately 580 meters south-southeast of the surface exposure of the Climax granitic intrusive.
\end{abstract}

To construct the well, a 1.22-meter-diameter surface conductor hole was dry-hole augered and cased off to a depth of 35.7 meters below the surface. A 47-centimeter-diameter surface hole was then rotary-drilled to the depth of 488 meters and cased off to the depth of 333.2 meters. The hole diameter was then decreased to 31.1 centimeters, and the borehole was advanced to a depth of 652.6 meters and cased off to a depth of 577.8 meters. Hole size was reduced again to 25.1 centimeters for drilling to a total depth of 872.6 meters. Air-foam in conventional circulation was used for the rotary-drilled portion of the borehole. Problems encountered during drilling were excessive sloughing of borehole wall material due to borehole instability, and lost circulation. The drill pipe and bottom hole assembly became stuck at the depth of 872.6 meters, and were retrieved only after several days of effort. The project was unable to complete the well as planned due to persistent hole sloughing, and work at this site was suspended on November 12, 2002. A completion string has not been installed, and fill was tagged at the depth of 629.4 meters on November 12, 2002. A waterlevel check conducted on April 25, 2003, which found no water in the borehole, and the top of fill remained at 629.4 meters.

Detailed lithologic descriptions with stratigraphic assignments are included in this report. These are based on composite drill cuttings samples collected every 3 meters, and 21 sidewall samples taken at various depths between 351.1 and 573.0 meters, supplemented by incomplete geophysical log data. Detailed petrographic, geochemical, and mineralogical studies of rock samples were conducted on 22 samples of drill cuttings. Drilling began in tuffaceous alluvium, and the borehole penetrated Tertiaryage bedded tuffs of the Volcanics of Oak Spring Butte and carbonate sediments of Paleozoic age, which were encountered at a depth of 334 meters. The borehole unexpectedly penetrated granite at the depth of 538.9 meters in which drilling was stopped. Contact metamorphic rocks and intrusive dikes associated with the Cretaceous-age granitic intrusive and at least one significant fault zone were encountered. 
This page intentionally left blank. 


\section{Table of Contents}



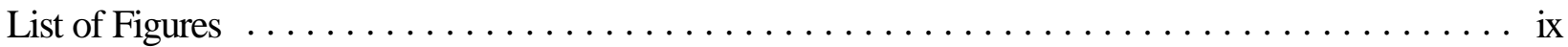



List of Acronyms and Abbreviations $\ldots \ldots \ldots \ldots \ldots \ldots \ldots \ldots \ldots \ldots \ldots \ldots \ldots \ldots \ldots \ldots \ldots$



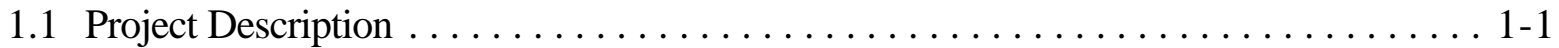

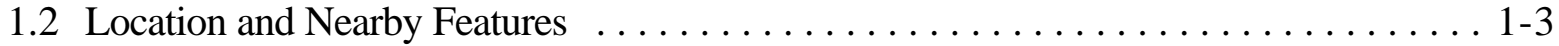

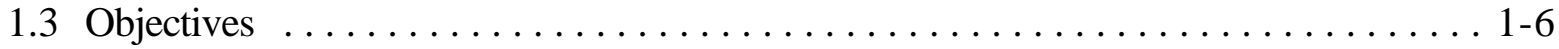

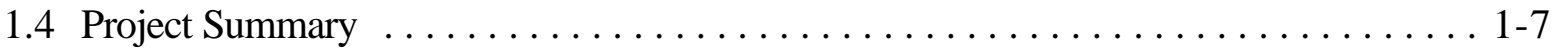

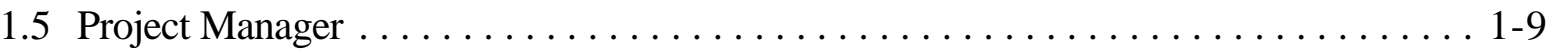

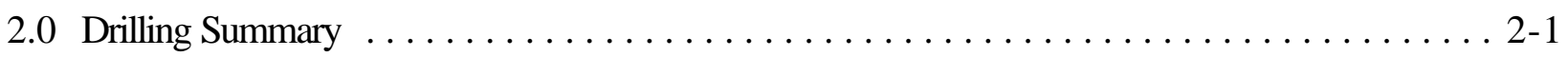

2.1 Introduction $\ldots \ldots \ldots \ldots \ldots \ldots \ldots \ldots \ldots \ldots \ldots \ldots \ldots \ldots \ldots \ldots \ldots \ldots \ldots \ldots \ldots \ldots \ldots \ldots, 1$

2.2 Drilling History $\ldots \ldots \ldots \ldots \ldots \ldots \ldots \ldots \ldots \ldots \ldots \ldots \ldots \ldots \ldots \ldots \ldots \ldots \ldots \ldots \ldots, 1$

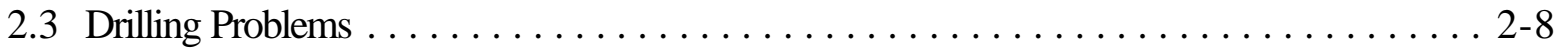



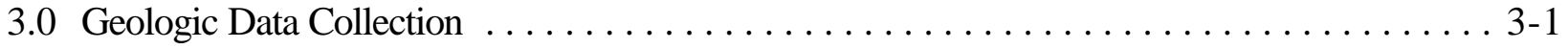

3.1 Introduction $\ldots \ldots \ldots \ldots \ldots \ldots \ldots \ldots \ldots \ldots \ldots \ldots \ldots \ldots \ldots \ldots \ldots \ldots \ldots \ldots \ldots \ldots \ldots \ldots \ldots, 1$

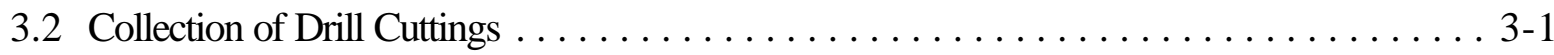

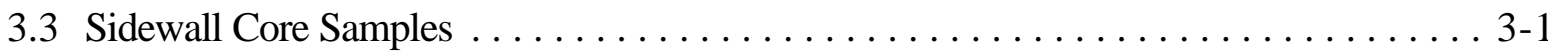

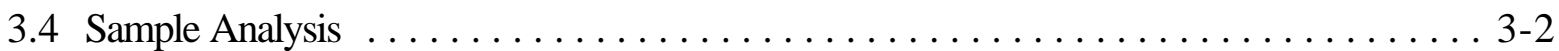

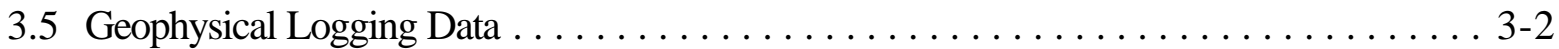



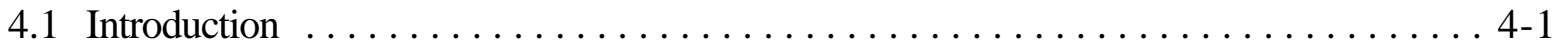

4.2 Geology $\ldots \ldots \ldots \ldots \ldots \ldots \ldots \ldots \ldots \ldots \ldots \ldots \ldots \ldots \ldots \ldots \ldots \ldots \ldots, 1$

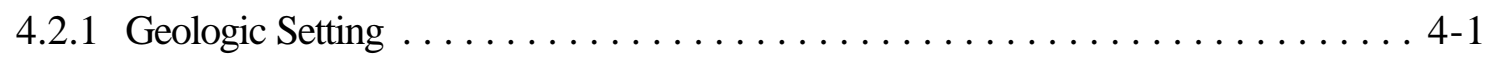

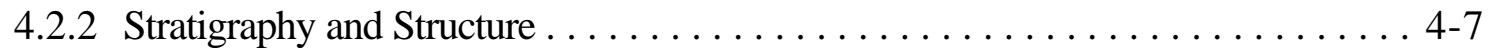

4.2 .3 Alteration $\ldots \ldots \ldots \ldots \ldots \ldots \ldots \ldots \ldots \ldots \ldots \ldots \ldots \ldots \ldots, 4-11$

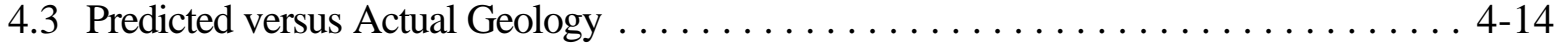






\section{Table of Contents (Continued)}

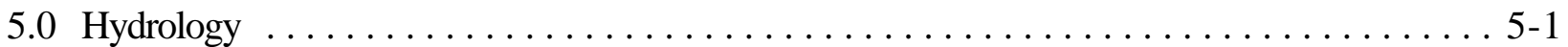

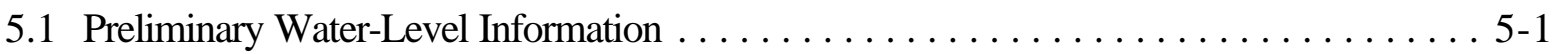

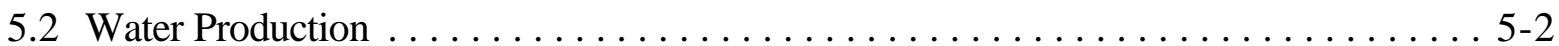

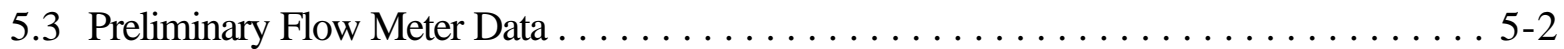

5.4 Preliminary Groundwater Characterization Samples $\ldots \ldots \ldots \ldots \ldots \ldots \ldots \ldots \ldots .2$

6.0 Precompletion and Open-Hole Development ......................... 6-1

7.0 Well Completion ....................................... $7-1$

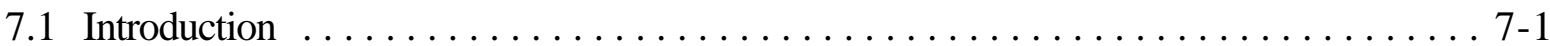



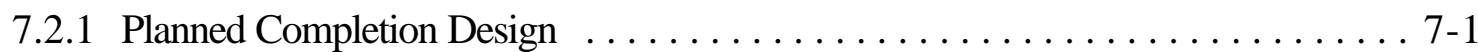

7.2.2 As-Built Completion Design $\ldots \ldots \ldots \ldots \ldots \ldots \ldots \ldots \ldots \ldots \ldots \ldots \ldots \ldots \ldots \ldots \ldots \ldots .2$

7.2.3 Proposed Completion Design for Unfinished Well ER-8-1 . . . . . . . . . . . 7-2

7.2.4 Rationale for Differences between Original Planned and New

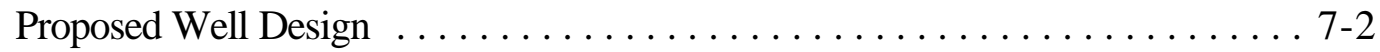

8.0 Planned and Actual Costs and Scheduling $\ldots \ldots \ldots \ldots \ldots \ldots \ldots \ldots \ldots \ldots \ldots \ldots \ldots \ldots \ldots \ldots$

9.0 Summary, Recommendations, and Lessons Learned $\ldots \ldots \ldots \ldots \ldots \ldots \ldots \ldots . . \ldots$. $9-1$

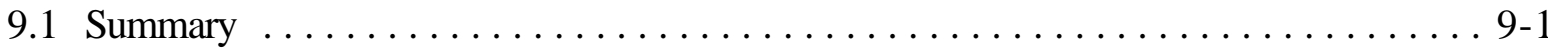



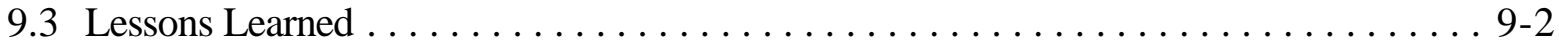

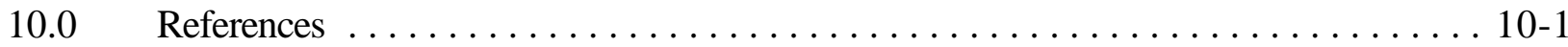

Appendix A - Drilling Data

A-1 Drilling Parameter Log for Well ER-8-1

A-2 Casing Data for Well ER-8-1

A-3 Well ER-8-1 Drilling Fluids and Cement Composition

Appendix B - Well ER-8-1 Fluid Management Data

Well ER-8-1 Fluid Disposition Reporting Form

Appendix C - Detailed Lithologic Log for Well ER-8-1

Appendix D - Geophysical Logs Run in Well ER-8-1

Distribution List 


\section{List of Figures}

Number

Title

Page

1-1 Locations of Correction Action Sites in the Yucca Flat/Climax Mine

Corrective Action Unit . . . . . . . . . . . . . . . . . . . . . . . . 1-2

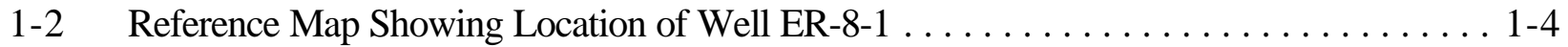

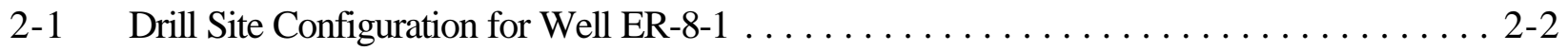

2-2 Well ER-8-1 Drilling and Completion History $\ldots \ldots \ldots \ldots \ldots \ldots \ldots \ldots \ldots \ldots$

4-1 Generalized Surface Geologic Map of the Nevada Test Site Area Showing

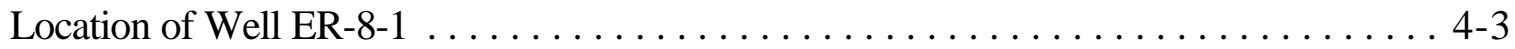

4-2 Surface Geologic Map of the Well ER-8-1 Site . . . . . . . . . . . . . . . 4-5

4-3 Geology and Hydrogeology of Well ER-8-1 . . . . . . . . . . . . . . . . . . 4-9

4-4 West-East Geologic Cross Section A-A' Through Well ER-8-1 . . . . . . . . . . . . . 4 4-12

4-5 North-South Geologic Cross Section B-B' Through Well ER-8-1 . . . . . . . . . . . . 4-13

4-6 Predicted and Actual Stratigraphy at Well ER-8-1 . . . . . . . . . . . . . . 4-15

4-7 West-East Hydrostratigraphic Cross Section C-C' Through Well ER-8-1 . . . . . . . 4 4-17

7-1 As-Built Completion Schematic for Well ER-8-1, November 2002 . . . . . . . . . . . . . 7-3

7-2 Wellhead Diagram for Well ER-8-1, November $2002 \ldots \ldots \ldots \ldots \ldots \ldots$. . . . . . . . . .

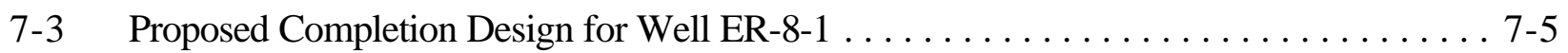

8-1 Planned versus Actual Construction Progress for Well ER-8-1 . . . . . . . . . . 8-2

8-2 Planned versus Actual Cost for Constructing Well ER-8-1 . . . . . . . . . . . 8-3 


\section{List of Tables}

Number

Title

Page

1-1 Well ER-8-1 Site Data Summary $\ldots \ldots \ldots \ldots \ldots \ldots \ldots \ldots \ldots \ldots \ldots \ldots \ldots \ldots$

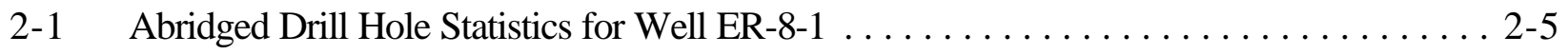

3-1 Sidewall Samples from Well ER-8 $-1 \ldots \ldots \ldots \ldots \ldots \ldots \ldots \ldots \ldots \ldots \ldots . \ldots \ldots$

3-2 Status of Rock Sample Analyses for Well ER-8-1 . . . . . . . . . . . . . 3-4

3-3 Well ER-8-1 Geophysical Log Summary . . . . . . . . . . . . . . . . 3-5

7-1 Proposed Completion String Construction Summary for Well ER-8-1 . . . . . . . . . 7-6

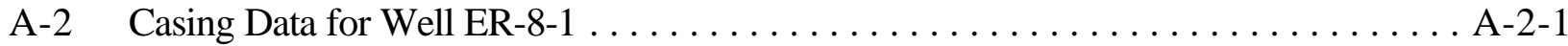

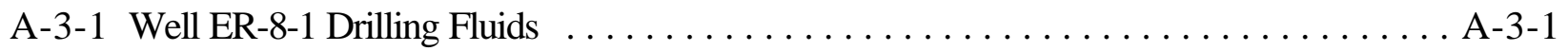

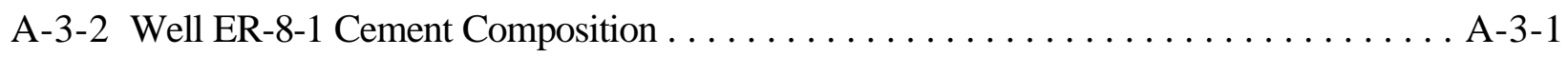

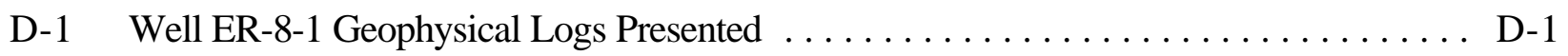




\section{List of Acronyms and Abbreviations}

\begin{tabular}{|c|c|}
\hline BHA & Bottom-hole assembly \\
\hline $\mathrm{BN}$ & Bechtel Nevada \\
\hline $\mathrm{C}$ & centigrade \\
\hline CAIP & Corrective action investigation plan \\
\hline CAU & Corrective action unit \\
\hline $\mathrm{cm}$ & centimeter(s) \\
\hline DOE & U.S. Department of Energy \\
\hline DOE/NV & Department of Energy, Nevada Operations Office \\
\hline DRI & Desert Research Institute \\
\hline $\mathrm{E}$ & east \\
\hline $\mathrm{F}$ & Fahrenheit \\
\hline FFACO & Federal Facilities Agreement Consent Order \\
\hline FAWP & Field Activity Work Plan \\
\hline FMP & Fluid Management Plan \\
\hline $\mathrm{ft}$ & foot (feet) \\
\hline gal & gallon(s) \\
\hline gpm & gallons per minute \\
\hline HES & Halliburton Energy Services \\
\hline HSU & hydrostratigraphic unit \\
\hline id & inside diameter \\
\hline in. & inch(es) \\
\hline IT & IT Corporation \\
\hline $\mathrm{km}$ & kilometer(s) \\
\hline LANL & Los Alamos National Laboratory \\
\hline LCA & Lower carbonate aquifer \\
\hline LCA3 & Lower carbonate aquifer - Thrust sheet \\
\hline $\mathrm{LiBr}$ & lithium bromide \\
\hline lpm & liters per minute \\
\hline $\mathrm{m}$ & meter(s) \\
\hline $\mathrm{Ma}$ & million years ago \\
\hline $\mathrm{mi}$ & mile(s) \\
\hline $\mathrm{N}$ & north \\
\hline NAD & North American Datum \\
\hline NNSA/NSO & National Nuclear Security Administration Nevada Site Office \\
\hline NTS & Nevada Test Site \\
\hline
\end{tabular}




\section{List of Acronyms and Abbreviations (continued)}

od

$\mathrm{S}$

Shaw

SWL

TD

$\mathrm{UCCU}$

UDI

UGTA

USGS

W outside diameter

South

Shaw Environmental, Inc.

Static water level

total depth

Upper clastic confining unit

United Drilling, Inc.

Underground Test Area

United States Geological Survey

west 


\subsection{Introduction}

\subsection{Project Description}

Well ER-8-1 was drilled for the U.S. Department of Energy (DOE), National Nuclear Security Administration Nevada Site Office (NNSA/NSO; formerly Nevada Operations Office, DOE/NV) in support of the Nevada Environmental Restoration Project at the Nevada Test Site (NTS), Nye County, Nevada. Well ER-8-1 is the second in a series of five wells drilled as part of the hydrogeologic investigation well drilling program for the Yucca Flat Corrective Action Unit (CAU). Data from these wells will allow for more accurate modeling of groundwater flow and radionuclide migration in the region. Some of the wells may also function as long-term monitoring wells.

The Yucca Flat hydrogeologic investigation well drilling program is part of the NNSA/NSO Environmental Restoration Division's Underground Test Area (UGTA) project at the NTS. The goals of the UGTA project include evaluating the nature and extent of contamination in groundwater due to underground nuclear testing, and establishing a long-term groundwater monitoring network. As part of the UGTA project, scientists are developing computer models to predict groundwater flow and contaminant migration within and near the NTS. To build and test these models, it is necessary to collect geologic, geophysical, and hydrologic data from new and existing wells to define groundwater migration pathways, migration rates, and quality.

The Yucca Flat hydrogeologic investigation well program is also part of the Corrective Action Investigation Plan (CAIP; IT, 2000) for the Yucca Flat and Climax Mine CAU (Number 97) (Figure 1-1). The CAIP is a requirement of the Federal Facility Agreement and Consent Order (FFACO, 1996) agreed to by the DOE, the Nevada Division of Environmental Protection, and the U.S. Department of Defense.

Well ER-8-1 was drilled as part of the Yucca Flat CAU Phase I drilling initiative. This well is intended to provide information on the steep potentiometric gradient at the north end of Yucca Flat, and to provide modeling constraints on groundwater flux into Yucca Flat from the north.

Shaw Environmental, Inc. (Shaw) was the principal environmental contractor for the project, and Shaw personnel collected geologic and hydrologic data during drilling. The drilling company was United Drilling, Incorporated (UDI), a subcontractor to Bechtel Nevada (BN). Site supervision, engineering, construction, inspection, and geologic support were provided by $\mathrm{BN}$. 


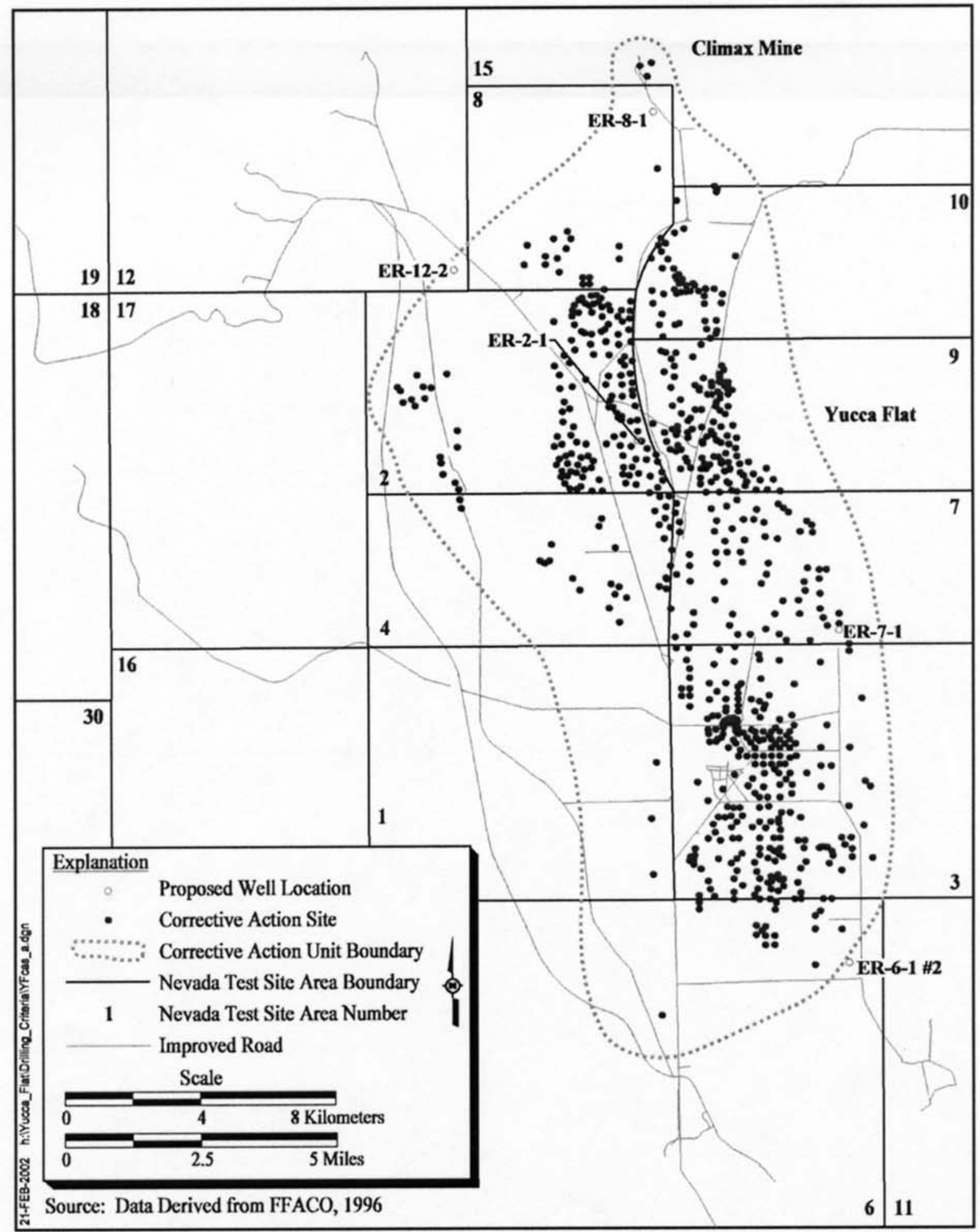

Figure 1-1

Locations of Corrective Action Sites in the Yucca Flat/Climax Mine Corrective Action Unit 
The roles and responsibilities of these and other contractors involved in the project are described in Contract Number DE-RP-08-95NV11808, and in BN Field Activity Work Plan (FAWP) Number D-010-002.03 (BN, 2002). The UGTA Technical Working Group, a committee of scientists and engineers comprising NNSA/NSO, Lawrence Livermore National Laboratory, Los Alamos National Laboratory (LANL), and contractor personnel, provided additional technical advice during drilling, design, and construction of the well. See Yucca Flat Hydrogeologic Investigation Wells Drilling and Completion Criteria (IT, 2002a) for descriptions of the general plan and goals of the Yucca Flat drilling initiative project, as well as specific goals for each planned well.

General guidelines for managing fluids used and generated during drilling, completion, and testing of UGTA wells are provided in the UGTA Fluid Management Plan, Revision 3 (FMP) (DOE/NV, 2002a), an attachment to the UGTA Waste Management Plan (DOE/NV, 2002b). Estimates of production of fluid and drill cuttings for the Yucca Flat holes are given in Appendix F of the drilling and completion criteria document for the Yucca Flat drilling project (IT, 2002a), along with sampling requirements and contingency plans for management of any hazardous waste produced. All activities were conducted according to the BN FAWP (BN, 2002) and the UGTA Project Health and Safety Plan (BN, 2001).

This report presents construction data and summarizes scientific data gathered during drilling of Well ER-8-1. Some of the information in this report is preliminary and unprocessed, but is being released with the drilling data for convenient reference. A well data report prepared by Shaw (Shaw, 2003) contains additional information on fluid management, waste management, and environmental compliance. Updated geologic information (including any changes in the geologic interpretation) will be compiled in the documentation package for the Yucca Flat hydrostratigraphic framework model to be prepared by BN. Information on well development, aquifer testing, and groundwater analytical sampling, if conducted, will be compiled and disseminated separately.

\subsection{Location and Nearby Features}

Well ER-8-1 is located in the northeast corner of NTS Area 8 at an elevation of 1,468.8 meters (m) (4,818.9 feet [ft]) (Figure 1-2). Surface drainage in this area is to the south-southeast, into Yucca Flat proper. The Nevada State (central zone) plane coordinates (North American Datum [NAD] 1983) at the wellhead are North (N) 6,273,456.0 m and East (E) 554,151.1 m. Additional site data are listed in Table 1-1. 


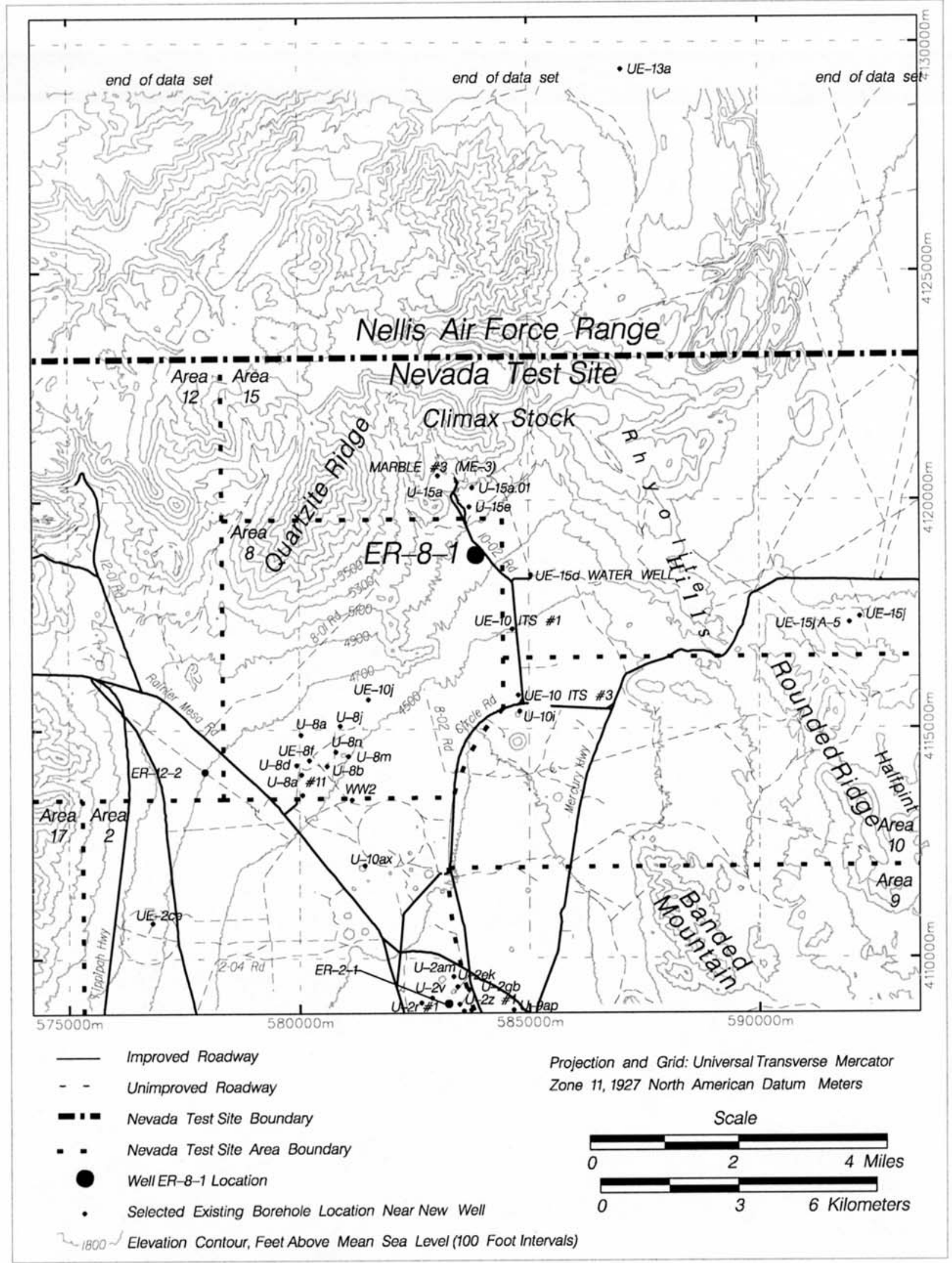

Figure 1-2

Reference Map Showing Location of Well ER-8-1 
Table 1-1

Well ER-8-1 Site Data Summary

\begin{tabular}{|c|c|}
\hline Well Designation & ER-8-1 \\
\hline Site Coordinates ${ }^{a}$ & 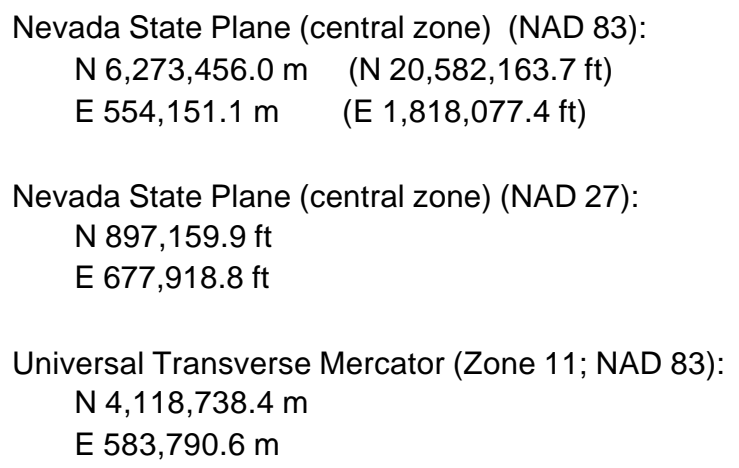 \\
\hline Surface Elevation ${ }^{b}$ & $1,468.8 \mathrm{~m}(4,818.9 \mathrm{ft})$ \\
\hline Drilled Depth & $872.6 \mathrm{~m}(2,863 \mathrm{ft})$ on November 4, 2002 \\
\hline Current Depth & 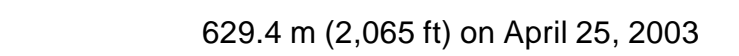 \\
\hline Fluid-Level Depth ${ }^{c}$ & $\begin{array}{c}561.4 \mathrm{~m}(1,842 \mathrm{ft}) \text { on October } 29,2002^{\mathrm{C}} \\
\text { None on April } 25,2003^{\mathrm{d}}\end{array}$ \\
\hline Fluid-Level Elevation & $\begin{array}{c}907.4 \mathrm{~m}(2,976.9 \mathrm{ft})^{\mathrm{c}} \\
\text { None on April } 25,2003^{\mathrm{d}}\end{array}$ \\
\hline
\end{tabular}

a Measurement made by BN Survey.

b Measurement made by BN Survey. Elevation at top of construction pad. 1929 National Geodetic November 4, 2002 Vertical Datum.

c Preliminary composite fluid level on October 29, 2002, during logging operations, while hole was at drilled depth of $652.6 \mathrm{~m}(2,141 \mathrm{ft})$.

d No water detected to top of fill at $629.4 \mathrm{~m}(2,065 \mathrm{ft})$ on April 25, 2003.

The well site is approximately $580 \mathrm{~m}(1,900 \mathrm{ft})$ southeast of (at closest approach) the surface trace of the Boundary fault, which forms the southeastern boundary of the Climax stock. This site was selected to be near the Climax stock, but far enough east of the Boundary fault that the well would penetrate the Paleozoic carbonate aquifer without encountering the Cretaceous-age intrusive granitic body. In addition, the well is sited on the up-thrown block (west of the surface trace) of the Yucca fault to minimize the total depth of the borehole required to encounter the regional carbonate aquifer. The

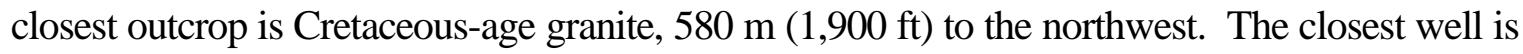
UE-15d, an inactive water well 1.3 kilometers $(\mathrm{km})$ (0.8 miles [mi]) east-southeast of Well ER-8-1. The closest active water well is Water Well 2, located about $5.9 \mathrm{~km}(3.7 \mathrm{mi})$ southwest of Well ER-8-1. 
The three closest underground nuclear tests to the Well ER-8-1 location were TINY TOT (U-15e), HARD HAT (U-15a), and PILE DRIVER (U-15a.01) (DOE/NV, 2000a). All three tests were conducted in granitic rocks within the Climax stock. Well ER-8-1 is sited approximately $1.2 \mathrm{~km}$ $(0.7 \mathrm{mi})$ south-southeast of the closest test, TINY TOT. Figure 1-1 shows the locations of these tests (and others in the Yucca Flat CAU) in relation to Well ER-8-1. Additional information pertaining to the three tests is provided in the criteria document (IT, 2002a).

\subsection{Objectives}

Well ER-8-1 was proposed as a moderately deep (1,066.8 $\mathrm{m}[3,500 \mathrm{ft}])$ hydrologic and geologic investigation well that will help characterize the hydrogeology of northern Yucca Flat. The primary purpose of Well ER-8-1 was to obtain data that constrain models of groundwater flow into Yucca Flat from the north, and that enhance the understanding of the steep potentiometric gradient at the north end of Yucca Flat (IT, 2002a, Plate 3). The construction of this well also addresses comments by the peer reviewers of the draft CAIP for Yucca Flat and the Climax area (DOE/NV, 2000b) concerning the need for adequately characterizing the former Climax Mine test area. Note that the Climax Mine and the Yucca Flat underground testing areas, originally defined as two separate CAUs in the original FFACO (1996), are now combined into a single CAU.

Virtually no deep geologic or hydrologic data are available for this complex and hydrologically important area of Yucca Flat. A viable interpretation for this area presented in the draft hydrostratigraphic framework model for Yucca Flat (Gonzales and Drellack, 1999) shows a hydrogeologic barrier around the north end of the valley consisting of Precambrian quartzite (lower clastic confining unit) to the northeast, Climax granite due north, and rocks of the Eleana Formation and Chainman Shale (upper clastic confining unit) in the northwest.

Information from the completion, sampling, and later hydraulic testing, of Well ER-8-1 will be used to enhance the hydrogeologic framework model and provide the necessary hydraulic parameters for subsequent flow and transport modeling for the Yucca Flat/Climax Mine CAU. Because of its downgradient position from the former Climax underground testing area, Well ER-8-1 might also be a favorable location for a long-term monitoring well.

Well-specific scientific objectives, as discussed in Appendix D of the drilling criteria document (IT, 2002a), include the following: 
- Obtain geologic samples and geophysical data that will aid in defining hydrostratigraphic units (HSUs) and characterizing any geologic structures encountered. This geologic information will reduce uncertainties in the hydrogeologic framework model, especially regarding:

» Extent and thickness of the upper thrust plate (Yucca Flat) of the lower carbonate (LCA) aquifer and the upper clastic confining unit (UCCU)

» Character of structural features such as the $\mathrm{CP}$ thrust fault

- Obtain properties of the HSUs penetrated, especially detailed fracture data for overall characterization of the UCCU and the LCA.

- Obtain representative aqueous geochemistry samples from the LCA to establish water chemistry and age.

Additional data that will help refine knowledge of the hydrology in northern Yucca Flat will be obtained during later hydraulic testing at this well, which is beyond the scope of this report. Specific criteria for these later tests will be defined elsewhere, but ultimately, Well ER-8-1 is expected to provide the following:

- Data for determination of vertical and horizontal conductivity

- Hydraulic properties of the HSUs penetrated.

\subsection{Project Summary}

This section summarizes Well ER-8-1 construction operations; the details are provided in Sections 2.0 through 8.0 of this report.

The surface conductor hole was constructed by augering a 121.9-centimeter (cm) (48-inch [in.]) diameter hole to a depth of $36.6 \mathrm{~m}$ (120 ft) and installing a string of 30-in. conductor casing to $35.7 \mathrm{~m}$ (117 ft). Drilling of the main hole with an 181/2-in. rotary bit, using an air-water-foam fluid (with a polymer additive as required) in conventional circulation, began on October 13, 2002. A suitable depth to set the surface casing was reached at $488 \mathrm{~m}(1,601 \mathrm{ft})$ as planned. At this point, drilling was suspended for geophysical logging, and then the $13 \mathrm{~d}$-in. surface casing string was landed at $333.2 \mathrm{~m}$ $(1,093.3 \mathrm{ft})$ on October 22, 2002. Borehole sloughing and accumulation of fill prevented the surface casing from being set closer to the drilled depth. Drilling continued with a 121/4-in. bit to the depth of $652.6 \mathrm{~m}(2,141 \mathrm{ft})$. At this point drilling was again suspended for geophysical logging, and the 103/4-in.

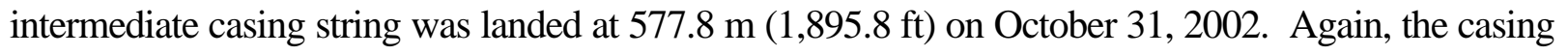
string could not be set to the desired depth due to hole sloughing and accumulating fill. The borehole 


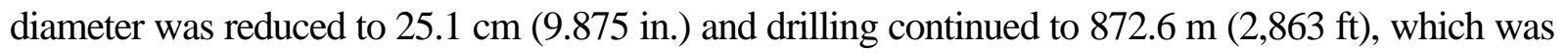
reached on November 4, 2002. At this point circulation was lost and the drill pipe became stuck. The drill pipe and bottom hole assembly (BHA) were extracted after nearly a week of intense efforts. Continued hole instability prompted the NNSA/NSO project manager to suspend drilling operations at Well ER-8-1 on November 12, 2002. The hole was terminated at $872.6 \mathrm{~m}(2,863 \mathrm{ft}), 194.2 \mathrm{~m}$ $(637 \mathrm{ft})$ short of the intended total depth (TD) of 1,066.8 $\mathrm{m}(3,500 \mathrm{ft})$.

Water production was first noted at the depth of approximately $317.9 \mathrm{~m}(1,043 \mathrm{ft})$, and reached a maximum of approximately 190 liters per minute (lpm) (50 gallons per minute [gpm]) before the surface casing was installed. During geophysical logging operations on October 29, 2002, while at a drilled depth of $652.6 \mathrm{~m}(2,141 \mathrm{ft})$, the composite fluid level was measured at the depth of $556.0 \mathrm{~m}(1,824 \mathrm{ft})$. However, on April 25, 2003, no fluid was detected in the open borehole to the top of fill at $629.4 \mathrm{~m}$ $(2,065 \mathrm{ft})$. No radionuclides above background levels were encountered during drilling of Well ER-8-1.

Composite drill cuttings were collected every $3.0 \mathrm{~m}$ (10 ft) from $36.6 \mathrm{~m}$ (120 ft) to TD, and 21 sidewall core samples were taken at various depths between 351.1 and $573.0 \mathrm{~m}$ (1,152 and 1,880 ft). Openhole geophysical logging of the well was conducted to help verify the geology and characterize the hydrology of the rocks; some logs also aided in the construction of the well by indicating borehole volume and condition. The lower $290.8 \mathrm{~m}$ (954 ft) of the borehole was not logged due to accumulation of fill. The well penetrated $42.7 \mathrm{~m}$ (140 ft) of tuffaceous alluvium, $291.4 \mathrm{~m}$ (956 ft) of vitric and zeolitic bedded tuffs related to the Volcanics of Oak Spring Butte Group (Tunnel bed 2 and older tuffs), $204.8 \mathrm{~m}$ (672 ft) of undifferentiated Paleozoic-age dolomite, and $333.8 \mathrm{~m}$ (1,095 ft) of Cretaceous-age granite in which Well ER-8-1 reached TD.

The well was not completed as planned. On November 12, 2002, prior to releasing UDI, fill was tagged at $629.4 \mathrm{~m}$ (2,065 ft). Well ER-8-1 was only partially successful in achieving the design objectives. This was partly due to unexpectedly encountering Cretaceous-age granite and partly due to the inability to complete the well because of persistent hole sloughing problems. It is possible, however, that the UGTA Program will revisit this well and be able to pursue additional objectives by the installation of a piezometer tube to the current drilled depth of the well. 


\subsection{Project Manager}

Inquiries concerning Well ER-8-1 should be directed to the UGTA Project Manager at:

U.S. Department of Energy

National Nuclear Security Administration

Nevada Site Office

Environmental Restoration Division

Post Office Box 98518

Las Vegas, Nevada 89193-8518 
This page intentionally left blank. 


\subsection{Drilling Summary}

\subsection{Introduction}

This section contains detailed descriptions of the drilling process and fluid management issues.

The general drilling requirements for all Yucca Flat wells were provided in Yucca Flat Hydrogeologic Investigation Wells Drilling and Completion Criteria (IT, 2002a). Specific requirements for Well ER-8-1 were outlined in FAWP Number D-010-002.03 (BN, 2002), and no verbal change orders were issued. Figure 2-1 shows the layout of the drill site. Figure 2-2 is a chart of the drilling and completion history for Well ER-8-1. A summary of drilling statistics for the well is given in Table 2-1. The following information was compiled primarily from $\mathrm{BN}$ daily drilling reports.

\subsection{Drilling History}

Field operations at Well ER-8-1 began on September 16, 2002, when BN drillers used an auger rig to drill a 121.9-cm (48-in.) diameter conductor hole to the depth of $36.6 \mathrm{~m}$ (120 ft). A string of 30-in. conductor casing was set at the depth of $35.7 \mathrm{~m}$ (117 ft). The bottom of the conductor casing was cemented inside to $31.7 \mathrm{~m}$ (104 ft), and the annulus was cemented from the bottom of the casing to ground level on September 25, 2002.

The UDI crews rigged up the Wilson Mogul 42B Double Drum Rig Number 5, October 9 to 3, 2002. Drilling resumed through the cement at the bottom of the 30-in. casing with a center-punch assembly consisting of an 181/2-in. rotary bit mounted below a 26 -in. hole opener, and using a mix of air, water, and foam ("air-foam") in conventional circulation. When the 181/2-in. bit reached a depth of $39.2 \mathrm{~m}$ (128.5 ft) and the 26-in. hole opener had cleared the bottom of the 30-in. casing, the center-punch assembly was removed to replace the hole opener with a new 181/2-in bit, and drilling resumed.

Drilling of the main hole with an 181/2-in. rotary bit and air-foam began October 14, 2002. The first water production was noted by Shaw personnel at a depth of approximately $317.9 \mathrm{~m}(1,043 \mathrm{ft}) \mathrm{on}$

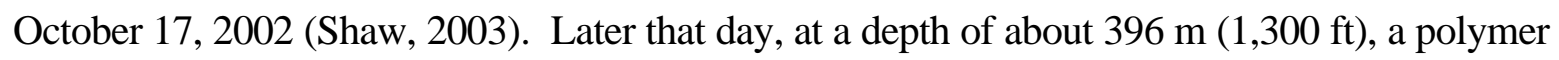
additive was added to the air-foam injection mix. The amounts of polymer and foaming agent in the drilling fluid, and the fluid injection rate, were adjusted as necessary during drilling to maintain superior circulation and penetration rate, and to minimize borehole sloughing. 


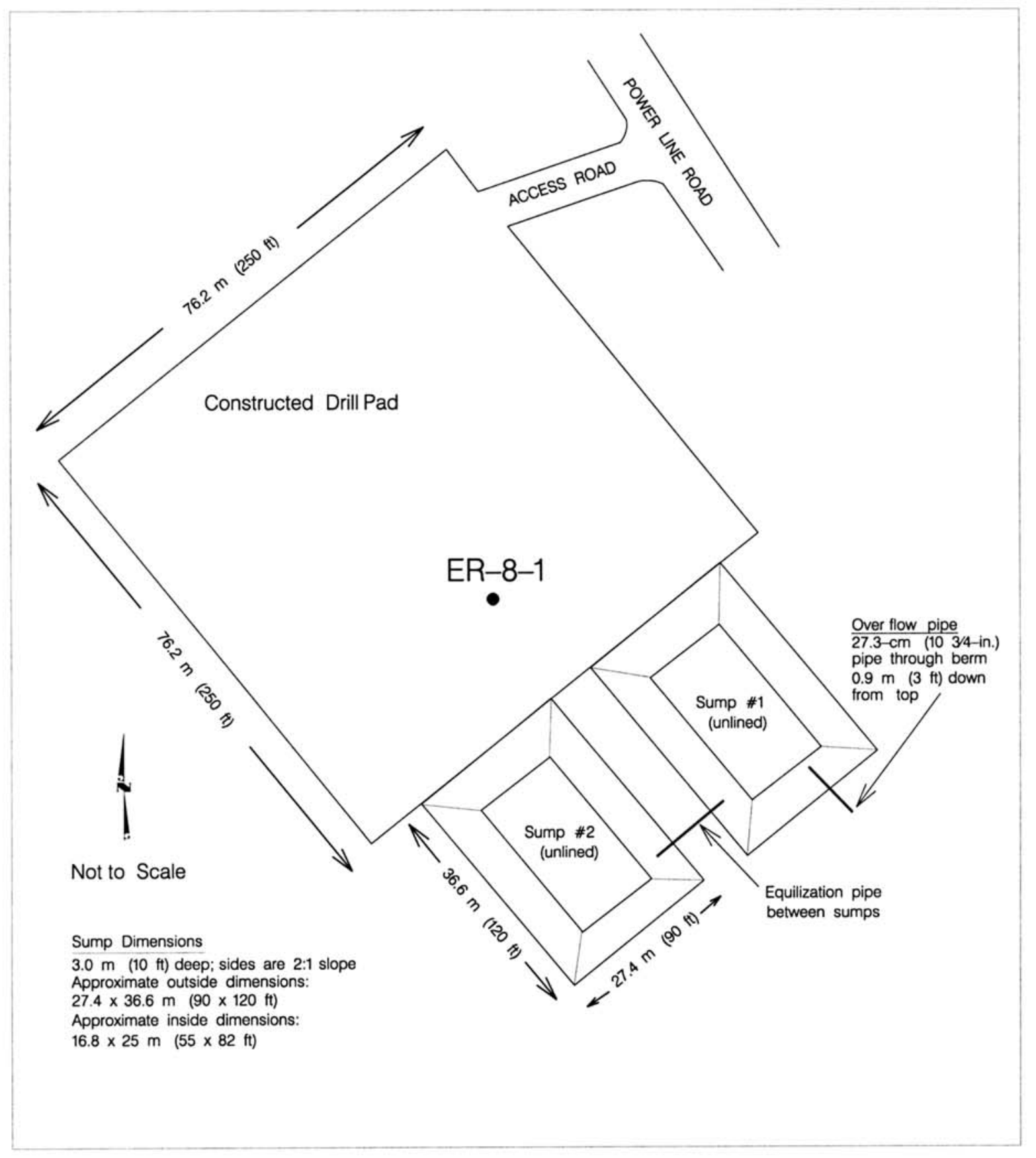

Figure 2-1

Drill Site Configuration for Well ER-8-1 


\section{WELL ER-8-1 SUMMARY}

Activity

Begin drilling conductor hol

Conductor hole completed and

30-in. casing set to $36.7 \mathrm{~m}$ (117 $\mathrm{ft}$ ):

Begin drilling 18 12-in. surface hole:

Det 13 38-in. surface casing at $333,2 \mathrm{ft})$

Drill $12 v_{4}$-in. hole to $652.8 \mathrm{~m}(2,141 \mathrm{ft})$

m (1,895.8fif): 10/31/2002

at TD of $872.6 \mathrm{~m} \mathrm{(2,863 \textrm {fl } ) : \quad 1 1 / 0 4 / 2 0 0 2}$

Recovered drill pipe and BHA:

\begin{tabular}{ll}
$11 / 13 / 2002$ \\
\hline
\end{tabular}

omplete rigging down site:

$\begin{array}{ll} & \text { LEGEND } \\ \text { bbl } & \text { Barrels } \\ \text { bgs } & \text { below ground surface } \\ \text { BHA } & \text { Bottom hole assembly } \\ \text { BN } & \text { Bechtel Nevada } \\ \text { cu ft } & \text { cubic feet } \\ \text { cu m } & \text { cubic meter(s) } \\ \text { DP } & \text { Drill pipe } \\ \text { ft } & \text { foot (feet) } \\ \text { gpm } & \text { gallons per minute } \\ \text { HES } & \text { Halliburton } \\ \text { in. } & \text { inch(es) } \\ \text { Ipm } & \text { liters per minute } \\ \text { m } & \text { meter(s) } \\ \text { TD } & \text { Total depth } \\ \text { TIH } & \text { Trip into hole } \\ \text { TOC } & \text { Top of cement } \\ \text { TOF } & \text { Top of fluid } \\ \text { TOH } & \text { Trip out of hole } \\ \text { UDI } & \text { United Drilling, Inc. } \\ \text { WOC } & \text { Wait on cement }\end{array}$

FIGURE 2-2

WELL ER-8-1

DRILLING AND COMPLETION

HISTORY

SHEET 1 OF 2

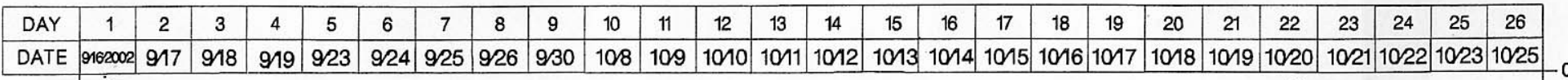

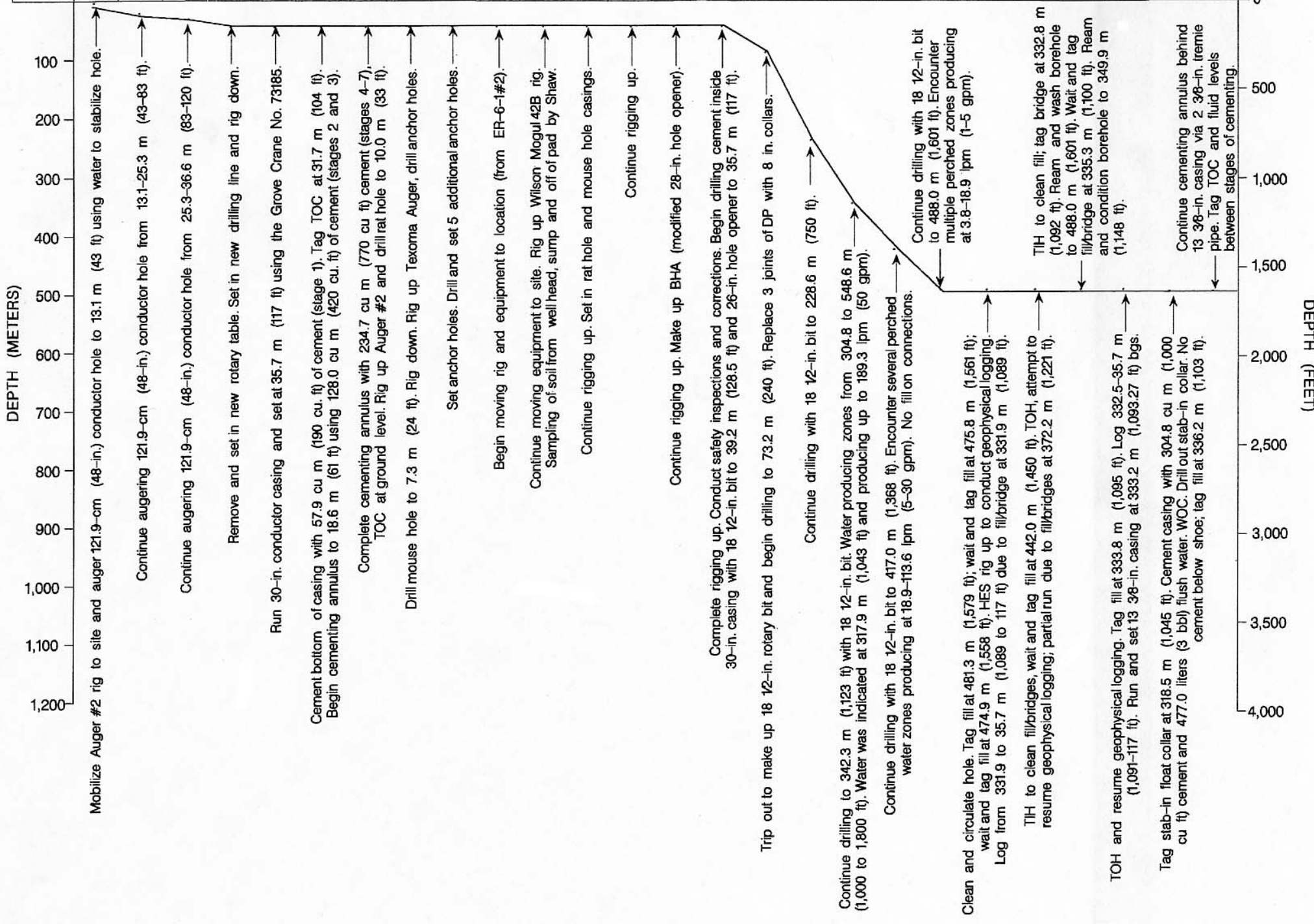




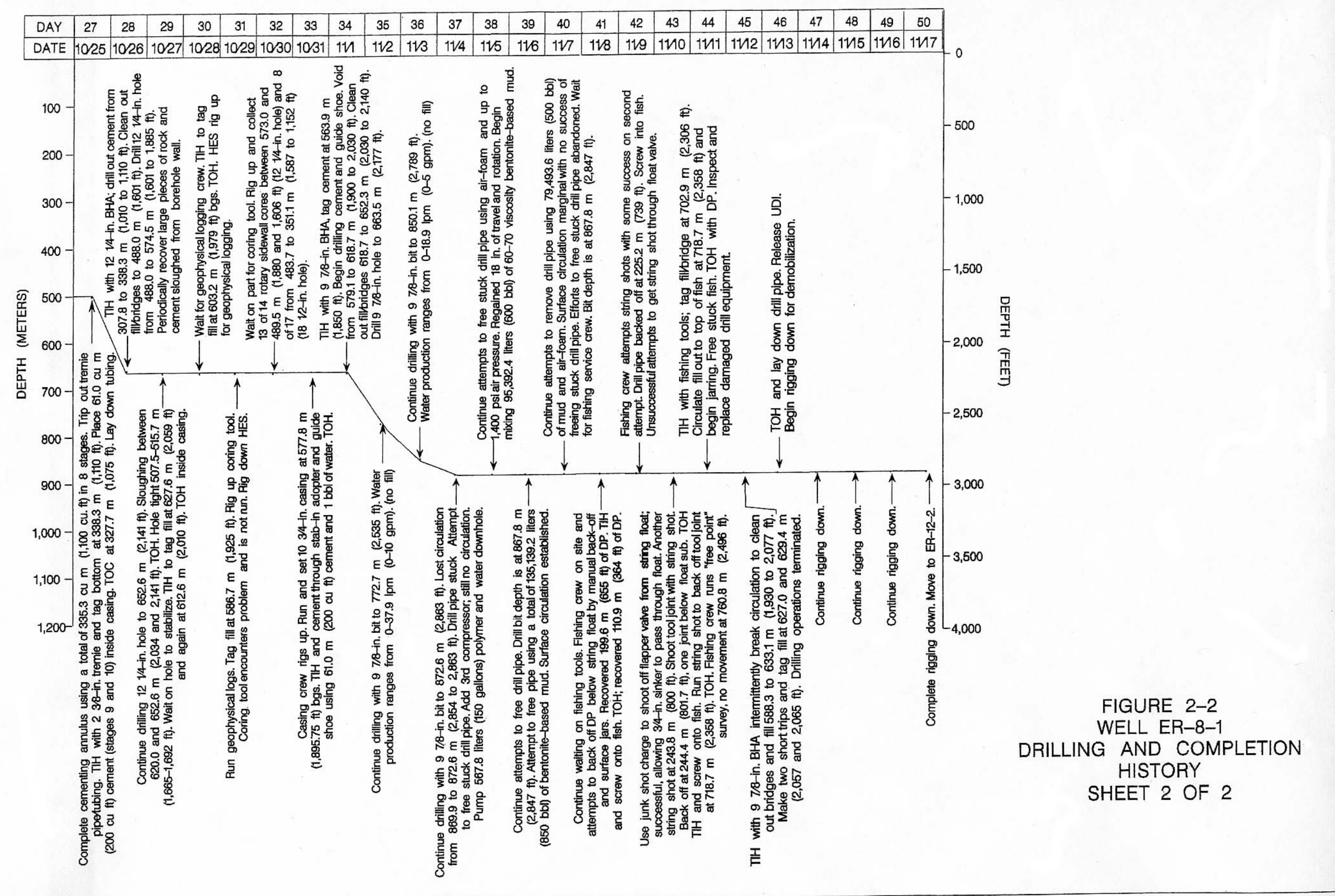




\section{Table 2-1}

\section{Abridged Drill Hole Statistics for Well ER-8-1}

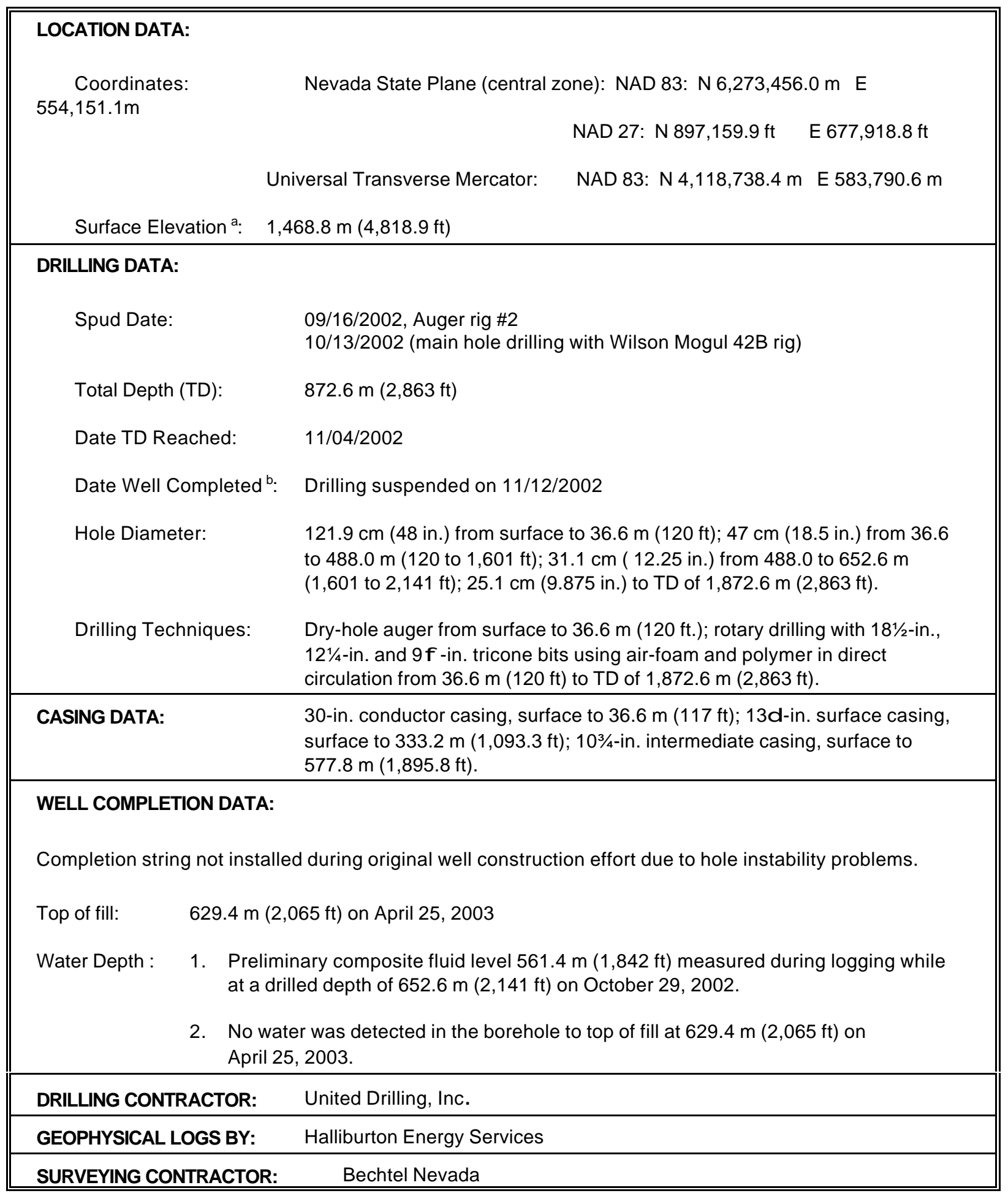

a Elevation of ground level at wellhead. 1929 National Geodetic Vertical Datum.

b Decision by NNSA/NSO to terminate drilling activities. Site may be revisited at a later date. 
The borehole was advanced to the planned casing point of $488.0 \mathrm{~m}(1,601 \mathrm{ft})$ with no problems. No fill (due to sloughing of the borehole wall) had been encountered when drilling was stopped to add drill pipe (make a connection). The drillers circulated the air-foam system to clean and condition the hole, pulled the drill string off the bottom, and waited about 30 minutes before trying to tag bottom again. Fill was tagged three times: at the depths of 481.3, 475.8, and $474.9 \mathrm{~m}(1,579,1,561$, and 1,558 $\mathrm{ft}$, respectively). Halliburton Energy Services (HES) rigged up to conduct the planned geophysical logging. However, the logging tool encountered a bridge of sloughed material at $331.9 \mathrm{~m}(1,089 \mathrm{ft})$. The drilling crew lowered the BHA into borehole to clean out the fill and bridges, and then after pulling the BHA up briefly, again tagged fill at $442.0 \mathrm{~m}(1,450 \mathrm{ft})$. A second attempt at logging was stopped by another bridge at $372.2 \mathrm{~m}(1,148 \mathrm{ft})$, so logging was conducted in the interval 35.7 to $332.5 \mathrm{~m}$ (117 to $1,091 \mathrm{ft}$ ).

A casing subcontractor landed a string of $13 \mathrm{~d}$-in. casing that has ribbon stabilizers (centralizers) installed above the guide shoe, at the middle and at the top of the first casing joint, and at the top of the second joint. A stab-in float collar was installed between the first and second joints. The casing was landed at a depth of $333.2 \mathrm{~m}(1,093.3 \mathrm{ft})$ on October 22, 2002, about $0.5 \mathrm{~m}(1.7 \mathrm{ft})$ above $154.2 \mathrm{~m}$ (506 ft) of fill that had accumulated in the bottom of the surface hole prior to and during geophysical logging. After the stab-in sub was seated in the float shoe, the seal was checked by pumping air down the drill pipe. Pre-flush clear water was pumped down the casing and the annulus prior to cementing. Type II neat cement was pumped inside the casing through the stab-in sub, followed by flush water to displace the cement into the annulus. The top of cement in the annulus behind the casing was tagged with a tubing string at the depth of approximately $327.7 \mathrm{~m}(1,075 \mathrm{ft})$, and then the annulus was cemented to ground level with Type II neat cement. Cementing of the surface casing was completed on October 25, 2002. The top of cement inside the casing was tagged at $307.8 \mathrm{~m}$ (1,010 ft) when the BHA was lowered back into the hole. Upon drilling out the stab-in collar it was noted that there was no cement immediately below the shoe, and fill was tagged at $336.2 \mathrm{~m}(1,103 \mathrm{ft})$, indicating a void in the interval 333.1 to $336.2 \mathrm{~m}$ (1,093 to $1,103 \mathrm{ft})$. Additional cement was placed from top of fill up into the casing.

After drilling cement from 307.8 to $335.3 \mathrm{~m}$ (1,010 to $1,100 \mathrm{ft})$ and fill/bridges to $488 \mathrm{~m}(1,601 \mathrm{ft})$, new 31.1-cm (12.25-in.) diameter borehole was advanced through the formation to the depth of $652.6 \mathrm{~m}(2,141 \mathrm{ft})$. Granite was encountered at the depth of $538.9 \mathrm{~m}(1,768 \mathrm{ft})$, and fill was encountered during drilling in the interval 620.0 to $652.6 \mathrm{~m}$ (2,034 to 2,141 ft) (see Section 2.3 for 
more information on drilling problems). Drilling was stopped at $652.6 \mathrm{~m}(2,141 \mathrm{ft})$ on October 27, 2002, for geophysical logging before installation of the intermediate casing.

The logging crew experienced difficulties with obstacles (fill and bridges of sloughed material) in the borehole and problems with logging tools. The casing crew arrived on October 31, 2002, and landed the 103/4-in. intermediate casing at $577.8 \mathrm{~m}$ (1,895.8 ft). The casing was cemented through a stab-in adapter and guide shoe with neat cement followed by flush water. The top of cement was later tagged inside the casing at $563.9 \mathrm{~m}(1,850 \mathrm{ft})$ with a new $9 \mathrm{f}$-in. bit and BHA.

Drilling resumed through the cement on November 1, 2002. After drilling out the cement, the drillers encountered a void from 79.1 to $618.7 \mathrm{~m}$ (1,900 to 2,030 ft) and fill from 618.7 to $652.3 \mathrm{~m}$ (2,030 to 2,140 ft). They finally advanced the $25.1-\mathrm{cm}(9.875-\mathrm{in}$.) borehole to $872.6 \mathrm{~m}(2,863 \mathrm{ft})$ through the granite with little or no fill at connections and water production of less than 19 lpm (5 gpm). On November 4, 2002, at the depth of $872.6 \mathrm{~m}$ (2,863 ft), circulation was lost and the drill pipe became stuck.

After eight days of effort, which included the procurement of a "fishing" services subcontractor, the stuck drill pipe and BHA were successfully retrieved. However, attempts to resume drilling were impeded by continued borehole sloughing. The decision was made by NNSA/NSO on November 12, 2002, to suspend drilling activities at Well ER-8-1. The UDI crew was released and they began to rig down on November 14, 2002, moving the drill rig and equipment to the Well ER-12-2 site. A borehole deviation survey was not run in Well ER-8-1 after termination of drilling operations, but may be done at a later date.

On November 12, 2002, approximately $243.2 \mathrm{~m}$ (798 ft) of fill remained in the borehole, as indicated by a tag at the depth of $629.4 \mathrm{~m}$ (2,065 ft). On April 25, 2003, the level of fill remained at $629.4 \mathrm{~m}$ $(2,065 \mathrm{ft})$, indicating that the uncased portion of the borehole is relatively stable.

A graphical depiction of drilling parameters including penetration rate, rotary revolutions per minute, pump pressure, and weight on the bit is presented in Appendix A-1. See Appendix A-2 for a listing of casing materials. Drilling fluids and cements used in Well ER-8-1 are listed in Appendix A-3. 


\subsection{Drilling Problems}

The BN FAWP for Well ER-8-1 (BN, 2002) contained provisions for setting intermediate casing in the event that unstable hole conditions or high water production caused drilling difficulties.

The borehole was advanced to the planned casing point of $488.0 \mathrm{~m}(1,601 \mathrm{ft})$ with no apparent problems, though some fill was noted at a few connections. Minor water production of up to $190 \mathrm{lpm}$ (50 gpm) was produced from perched water zones starting at the depth of about $318 \mathrm{~m}$ (1,043 ft). However, bridges were encountered during geophysical logging at $331.9 \mathrm{~m}$ (1,089 ft) on October 19, 2002. Several attempts were made to clean out the hole, but logging tools still encountered bridges at the depths of 333.8 and $372.2 \mathrm{~m}$ (1,095 and 1,221 ft). A large wash-out (portion of the borehole enlarged due to sloughing) had developed in the interval 326.7 to $334.1 \mathrm{~m}$ (1,072 to 1,096 ft), and it was planned to seal off this interval with a string of $13 \mathrm{~d}$-in. casing. However, fill material and bridges in the borehole prevented the casing from passing the depth of $333.2 \mathrm{~m}(1,093.2 \mathrm{ft})$ and the casing was set at that depth, but does not fully cover the washed-out interval. When drilling had reached the depth of $622.1 \mathrm{~m}$ $(2,041 \mathrm{ft})$ the decision was made to install 103/4-in. casing in order to control continued sloughing from the wash-out at the base of the $13 \mathrm{~d}$-in. casing and protect the borehole. Fill again blocked the lower portion of the borehole during geophysical logging operations.

After the 103/4-in. casing was set at the depth of $577.8 \mathrm{~m}(1,895.8 \mathrm{ft})$, drilling resumed and progressed

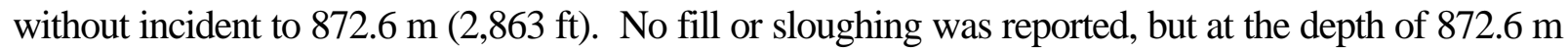
$(2,863 \mathrm{ft})$ circulation was lost. The subsequent collapse of drill cuttings that had been suspended in the

fluid stuck the drill pipe and BHA. The crew pumped various combinations of fluids down-hole (including polymer and water, and 70-viscosity bentonite mud) but could not free the pipe. Finally, a fishing service subcontractor was procured on November 7, 2002. After several attempts to back off and free the stuck drill pipe, the pipe and BHA were recovered on November 11, 2002. The drill crew tripped back into the borehole to clean out fill, but sloughing persisted. Late on November 12, 2002, the NNSA/NSO project manager made the decision to suspend further work at Well ER-8-1.

Drilling was stopped $194.2 \mathrm{~m}$ (637 ft) short of the planned TD of 1,066.8 m (3,500 ft) due to severe borehole sloughing problems. The UGTA project may revisit this site at a later date.

\subsection{Fluid Management}

Drilling effluent was monitored according to the methods prescribed in the UGTA FMP (DOE/NV, 2002a). The air-foam/polymer drill fluid was circulated down the inside of the drill string and back up the 
hole through the annulus (conventional or direct circulation) and then discharged into a sump. Water used to prepare drilling fluids came from the fill stand near Building 6-900 which is supplied by Water Well C1, located at the south end of Yucca Flat. Lithium bromide ( $\mathrm{LiBr})$ was added to the drill fluid as a tracer to provide a means of estimating groundwater production. The rate of water inflow was estimated from the dilution of the tracer in the drill fluid returns.

To manage the anticipated water production, two sumps were constructed prior to drilling (Figure 2-1). No contaminants were expected during drilling at this site, so neither sump was lined prior to drilling. Samples of drilling effluent were collected hourly and analyzed on site by BN Radiation Operations personnel for the presence of tritium. The onsite monitoring results indicate that tritium remained at background levels during the entire drilling operation (Shaw, 2003). Drilling fluids generated at Well ER-8-1 were not analyzed for lead, as per the Well ER-8-1 Fluid Management Strategy Letter (Wycoff, 2002).

Before fluids are discharged from a sump through the overflow pipe, the FMP requires that a sample be collected from the sump and analyzed off-site to verify onsite monitoring data and demonstrate compliance with the FMP. However, characterization samples were not collected at Well ER-8-1 due to the lack of water production during drilling.

The results of analyses of samples of drilling fluid collected at Well ER-8-1 during drilling operations indicate that all fluid quality objectives were met, as shown on the fluid management reporting form dated June 2, 2003 (Appendix B). The form lists volumes of solids (drill cuttings) and fluids produced during well-construction operations, Stages I and II (i.e., vadose- and saturated-zone drilling only; well development and aquifer testing will be conducted at a later date).

At the completion of Well ER-8-1 drilling operations, an estimated combined total of 1,445.5 cubic meters (381,861 gallons [gal]) of drilling fluid and cuttings remained in the sumps. The volume of solids produced was calculated using the diameter of the borehole (from caliper logs) and the depth drilled, and includes added volume attributed to a rock bulking factor. The volumes of fluids listed on the report are estimates of total fluid production, and do not account for any infiltration or evaporation of fluid from the sumps. 
This page intentionally left blank. 


\subsection{Geologic Data Collection}

\subsection{Introduction}

This section describes the sources of geologic data obtained from Well ER-8-1 and the methods of data collection. Improving the understanding of the subsurface structure, stratigraphy, and hydrogeology in northern Yucca Flat was among the primary objectives of Well ER-8-1, so the proper collection of geologic and hydrogeologic data from Well ER-8-1 was considered fundamental to successful completion of the project.

Geologic data collected at Well ER-8-1 consist of drill cuttings, rotary sidewall core samples, and partial geophysical log coverage. Data collection, sampling, transfer, and documentation activities were performed according to applicable contractor procedures.

\subsection{Collection of Drill Cuttings}

Composite drill cuttings were collected from Well ER-8-1 at 3-m (10-ft) intervals as drilling progressed

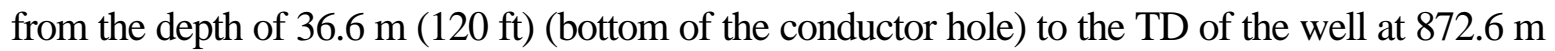
(2,863 ft). Triplicate samples were collected from 275 intervals, and in addition, the Shaw field representative collected two sets of reference samples from each of the cuttings intervals. One set was examined at the drill site for use in preparing field lithologic descriptions, and is now in the custody of Stoller-Navarro Joint Venture (Shaw's successor and the current environmental contractor for NNSA/NSO). The other set was sent to Giday WoldeGabriel (LANL), where it remains.

Additionally, a composite sample of drill cuttings (approximately 3.8 liters [1 gal]) was collected while drilling the pre-Tertiary carbonate section. Selected depths from this collection will be shipped to a commercial laboratory for paleontologic micro-fossil analysis. All other samples (i.e., 3 sets of 275 samples) are stored under secure, environmentally controlled conditions at the U.S. Geological Survey (USGS) Geologic Data Center and Core Library in Mercury, Nevada. One of these sample sets was sealed with custody tape at the rig site and remains sealed as an archive sample; one set was left unsealed in the original sample containers; and the third set was washed and stored according to standard USGS Core Library procedures.

\subsection{Sidewall Core Samples}

Sidewall core samples were collected by HES from Well ER-8-1 to verify the stratigraphy and lithology at selected locations. Sample locations were selected by the Shaw Field Representative on the basis of field lithologic logs (with consideration of borehole conditions determined from caliper 
logs). A wireline rotary sidewall coring tool was used to collect sidewall cores in the interval 351.1 to $573.0 \mathrm{~m}$ (1,152 to $1,880 \mathrm{ft})$ on October 30,2002 , before the $103 / 4$-in. intermediate casing string was installed. A total of 21 cores was retrieved out of 42 attempts. Table 3-1 1ists the recovery and stratigraphic assignment for each sample.

\subsection{Sample Analysis}

Twenty-two samples of drill cuttings from various depths in Well ER-8-1 were submitted to the LANL Earth and Environmental Sciences Division - Geology and Geochemistry laboratories for petrographic, mineralogic, and chemical analyses to aid in stratigraphic identification and for characterization of mineral alteration. All of the planned analyses have been completed, as shown on Table 3-2.

\subsection{Geophysical Logging Data}

Geophysical logs were run in the borehole to further characterize the lithology, structure, and water content of the rocks encountered. In addition, logs were run to evaluate borehole conditions and to determine the fluid levels during the course of drilling. Geophysical logging was conducted during two stages of drilling: prior to setting the $13 \mathrm{~d}$-in. surface casing at $488 \mathrm{~m}(1,601 \mathrm{ft})$ and prior to installing the 103/4-in. intermediate casing at the drilled depth of $652.6 \mathrm{~m}(2,141 \mathrm{ft})$. A complete listing of the logs, dates run, depths, and service companies is provided in Table 3-3. The logs are available from BN in Mercury, Nevada, and copies are on file at the office of Stoller-Navarro Joint Venture in Las Vegas, Nevada, and at the USGS Geologic Data Center and Core Library in Mercury, Nevada. Preliminary geophysical data from the logs are reproduced in Appendix D.

The overall quality of the geophysical data collected was good. However, borehole coverage is incomplete due to sloughing and bridging of the borehole (e.g., below about $579 \mathrm{~m}$ [1,900 ft] depth). Also, HES experienced problems with their wireline coring tool, which caused some delays. 
Table 3-1

Sidewall Samples from Well ER-8-1

\begin{tabular}{|c|c|c|c|c|c|}
\hline \multicolumn{2}{|c|}{\begin{tabular}{c}
\multicolumn{2}{c}{ Core Depth } \\
a \\
meters (feet)
\end{tabular}} & \multicolumn{2}{|c|}{$\begin{array}{c}\text { Recovery } \\
\text { centimeters (inches) } \\
\end{array}$} & \multirow{2}{*}{$\frac{\text { Formation }^{\mathbf{b}}}{\text { Pz undifferentiated }}$} & \multirow{2}{*}{$\begin{array}{l}\text { Lithology } \\
\text { Dolomite }\end{array}$} \\
\hline 351.1 & $(1,152)$ & 1.0 & $(0.4)$ & & \\
\hline 359.7 & $(1,180)$ & 5.1 & (2.0) & Pz undifferentiated & Dolomite \\
\hline 396.8 & $(1,302)$ & 3.0 & (1.2) & Pz undifferentiated & Dolomite \\
\hline 415.7 & $(1,364)$ & 2.0 & $(0.8)$ & Pz undifferentiated & Dolomite \\
\hline 427.9 & $(1,404)$ & 2.0 & $(0.8)$ & Pz undifferentiated & Dolomite \\
\hline 446.2 & $(1,464)$ & 3.0 & $(1.2)$ & Pz undifferentiated & Dolomite \\
\hline 478.5 & $(1,570)$ & 3.6 & (1.4) & Pz undifferentiated & Dolomite \\
\hline 483.7 & $(1,587)$ & 3.1 & $(1.2)$ & Pz undifferentiated & Dolomite \\
\hline 489.5 & $(1,606)$ & 5.1 & $(2.0)$ & Pz undifferentiated & Dolomite \\
\hline 507.2 & $(1,664)$ & 3.6 & (1.4) & Pz undifferentiated & Dolomite \\
\hline 515.1 & $(1,690)$ & 3.6 & $(1.4)$ & Pz undifferentiated & Dolomite \\
\hline 520.0 & $(1,706)$ & 4.3 & $(1.7)$ & Pz undifferentiated & Dolomite \\
\hline 526.4 & $(1,727)$ & 2.3 & $(0.9)$ & Pz undifferentiated & Dolomite \\
\hline 532.2 & $(1,746)$ & 0.6 & $(0.25)$ & Pz undifferentiated & Dolomite \\
\hline 537.7 & $(1,764)$ & 2.0 & $(0.8)$ & Pz undifferentiated & Dolomite/Marble \\
\hline 548.0 & $(1,798)$ & 4.1 & $(1.6)$ & $\mathrm{Kgc}$ & Granodiorite \\
\hline 554.4 & $(1,819)$ & 2.3 & $(0.9)$ & $\mathrm{Kgc}$ & Granodiorite \\
\hline 557.5 & $(1,829)$ & 2.0 & $(0.8)$ & $\mathrm{Kgc}$ & Granodiorite \\
\hline 563.9 & $(1,850)$ & 1.8 & $(0.7)$ & $\mathrm{Kgc}$ & Granodiorite \\
\hline 566.9 & $(1,860)$ & 3.1 & (1.2) & $\mathrm{Kgc}$ & Granodiorite \\
\hline 573.0 & $(1,880)$ & 5.1 & $(2.0)$ & $\mathrm{Kgc}$ & Granodiorite \\
\hline
\end{tabular}

a All samples are wireline rotary cores collected by Halliburton Energy Services on October 30, 2002.

b $\quad \mathbf{P z}=$ Paleozoic-age sedimentary rocks; $\mathbf{K g c}=$ Cretaceous-age granitic rocks 
Table 3-2

Status of Rock Sample Analyses for Well ER-8-1

\begin{tabular}{|c|c|c|c|c|c|c|}
\hline \multirow{3}{*}{$\begin{array}{c}\text { Depth }^{\mathbf{a}} \\
\text { meters (feet) }\end{array}$} & \multirow{3}{*}{$\begin{array}{l}\text { Sample } \\
\text { Type }^{\text {b }}\end{array}$} & \multicolumn{5}{|c|}{ Analyses Performed $^{c}$} \\
\hline & & \multirow{2}{*}{$\begin{array}{c}\text { Petrographic } \\
\text { PTS } \\
\end{array}$} & \multicolumn{2}{|c|}{ Mineralogic } & \multicolumn{2}{|c|}{ Chemical } \\
\hline & & & MP & XRD & XRF & $\mathrm{Fe}^{2+} / \mathrm{Fe}^{3+}$ \\
\hline $39.6(130)$ & DC & $\mathrm{C}$ & $\mathrm{N} / \mathrm{P}$ & $\mathrm{N} / \mathrm{P}$ & $\mathrm{N} / \mathrm{P}$ & $\mathrm{N} / \mathrm{P}$ \\
\hline $42.6(140)$ & DC & $\mathrm{C}$ & $\mathrm{N} / \mathrm{P}$ & $\mathrm{N} / \mathrm{P}$ & $\mathrm{N} / \mathrm{P}$ & $\mathrm{N} / \mathrm{P}$ \\
\hline $51.8(170)$ & DC & C & C & C & $\mathrm{C}$ & $\mathrm{C}$ \\
\hline $61.0(200) \mathrm{A}$ & DC & $\mathrm{C}$ & C & C & $\mathrm{C}$ & $\mathrm{C}$ \\
\hline $61.0(200) \mathrm{B}$ & DC & $\mathrm{N} / \mathrm{P}$ & $\mathrm{N} / \mathrm{P}$ & $\mathrm{C}$ & $\mathrm{N} / \mathrm{P}$ & $\mathrm{N} / \mathrm{P}$ \\
\hline $88.4(290)$ & $\mathrm{DC}$ & $\mathrm{C}$ & C & $\mathrm{C}$ & $\mathrm{C}$ & $\mathrm{C}$ \\
\hline $109.7(360)$ & DC & $\mathrm{C}$ & $\mathrm{C}$ & $\mathrm{C}$ & $\mathrm{C}$ & $\mathrm{C}$ \\
\hline $137.2(450)$ & DC & $\mathrm{C}$ & C & $\mathrm{C}$ & C & C \\
\hline $167.9(550)$ & DC & C & $\mathrm{C}$ & C & $\mathrm{C}$ & C \\
\hline $222.5(730)$ & DC & C & $\mathrm{C}$ & C & C & $\mathrm{C}$ \\
\hline $228.6(750)$ & DC & C & C & C & $\mathrm{C}$ & $\mathrm{C}$ \\
\hline $246.9(810)$ & $\mathrm{DC}$ & $\mathrm{C}$ & $\mathrm{C}$ & $\mathrm{C}$ & $\mathrm{C}$ & $\mathrm{C}$ \\
\hline $268.1(880) A$ & DC & C & $\mathrm{N} / \mathrm{P}$ & C & $\mathrm{N} / \mathrm{P}$ & $\mathrm{N} / \mathrm{P}$ \\
\hline 268.1 (880)B & DC & $\mathrm{N} / \mathrm{P}$ & $\mathrm{N} / \mathrm{P}$ & $\mathrm{N} / \mathrm{P}$ & $\mathrm{C}$ & $\mathrm{N} / \mathrm{P}$ \\
\hline 295.7 (970) & DC & $\mathrm{C}$ & C & $\mathrm{C}$ & C & $\mathrm{C}$ \\
\hline $313.9(1030)$ & DC & $\mathrm{C}$ & $\mathrm{N} / \mathrm{P}$ & $\mathrm{C}$ & $\mathrm{C}$ & $\mathrm{C}$ \\
\hline $347.5(1,140)$ & DC & $\mathrm{C}$ & C & $\mathrm{N} / \mathrm{P}$ & C & $\mathrm{N} / \mathrm{P}$ \\
\hline $387.1(1,270)$ & DC & $\mathrm{C}$ & $\mathrm{N} / \mathrm{P}$ & $\mathrm{C}$ & $\mathrm{C}$ & $\mathrm{C}$ \\
\hline $405.4(1,330)$ & $\mathrm{DC}$ & $\mathrm{C}$ & C & $\mathrm{C}$ & C & $\mathrm{C}$ \\
\hline $551.7(1,810)$ & DC & C & $\mathrm{N} / \mathrm{P}$ & $\mathrm{C}$ & $\mathrm{C}$ & C \\
\hline $762.0(2,500)$ & $\mathrm{DC}$ & $\mathrm{C}$ & $\mathrm{N} / \mathrm{P}$ & $\mathrm{C}$ & $\mathrm{C}$ & $\mathrm{C}$ \\
\hline $810.8(2,660)$ & $\mathrm{DC}$ & $\mathrm{C}$ & $\mathrm{N} / \mathrm{P}$ & $\mathrm{C}$ & $\mathrm{C}$ & $\mathrm{C}$ \\
\hline
\end{tabular}

a Depth represents base of 3.0-m (10-ft) sample interval for drill cuttings. All samples are drill cuttings that represent the lithologic character of the interval.

b Sample type: $\mathrm{DC}=$ Drill cuttings; $\mathrm{WRSC}=$ Wireline rotary sidewall core

C Status of analyses: $\mathbf{C}=$ analysis complete; $\mathbf{N} / \mathbf{P}=$ analysis not planned. Analysis type:

$\mathbf{P T S}=$ polished thin section; $\mathbf{M P}=$ electron microprobe $\mathbf{X R D}=\mathrm{x}$-ray diffraction; $\mathbf{X R F}=\mathrm{x}$-ray fluorescence; $\mathrm{Fe}^{2+} / \mathrm{Fe}^{3+}=$ wet chemical analysis for iron. 
Table 3-3

Well ER-8-1 Geophysical Log Summary

\begin{tabular}{|c|c|c|c|c|c|c|}
\hline Geophysical Log Type a & Log Purpose & $\begin{array}{l}\text { Logging } \\
\text { Service }\end{array}$ & $\begin{array}{l}\text { Date } \\
\text { Logged }\end{array}$ & Run Number & $\begin{array}{l}\text { Bottom of } \\
\text { Logged } \\
\text { Interval } \\
\text { meters (feet) }\end{array}$ & $\begin{array}{l}\text { Top of Logged } \\
\text { Interval }{ }^{\mathbf{b}} \\
\text { meters (feet) }\end{array}$ \\
\hline * Natural Gamma Ray Spectroscopy & $\begin{array}{l}\text { Stratigraphic correlation, mineralogy, } \\
\text { natural and man-made radiation }\end{array}$ & $\begin{array}{l}\text { Halliburton } \\
\text { Energy } \\
\text { Services }\end{array}$ & $\begin{array}{l}10 / 19 / 2002 \\
10 / 20 / 2002 \\
10 / 29 / 2002\end{array}$ & $\begin{array}{l}\text { SGR-1 } \\
\text { SGR-2 } \\
\text { SGR-3/ GR }\end{array}$ & $\begin{array}{l}328.3(1,077) \\
370.0(1,214) \\
581.9(1,909)\end{array}$ & $\begin{array}{c}15.2(50) \\
15.2(50) \\
274.3(900)\end{array}$ \\
\hline * Six Arm Caliper/Gamma Ray & $\begin{array}{l}\text { Borehole conditions, cement volume } \\
\text { calculation / } \\
\text { stratigraphic correlation }\end{array}$ & $\begin{array}{l}\text { Halliburton } \\
\text { Energy } \\
\text { Services }\end{array}$ & $\begin{array}{l}10 / 19 / 2002 \\
10 / 20 / 2002 \\
10 / 29 / 2002\end{array}$ & $\begin{array}{c}\text { CA6-1/ SGR-1 } \\
\text { CA6-2/ SGR-2 } \\
\text { CA6-2/ GR-8 }\end{array}$ & $\begin{array}{l}328.3(1,077) \\
370.0(1,214) \\
581.9(1,909)\end{array}$ & $\begin{array}{c}15.2(50) \\
15.2(50) \\
274.3(900)\end{array}$ \\
\hline${ }^{*}$ High Resolution Induction Log & $\begin{array}{l}\text { Lithologic determination / } \\
\text { borehole conditions / } \\
\text { stratigraphic correlation }\end{array}$ & $\begin{array}{l}\text { Halliburton } \\
\text { Energy } \\
\text { Services }\end{array}$ & $\begin{array}{l}10 / 21 / 2002 \\
10 / 29 / 2002\end{array}$ & $\begin{array}{l}\text { HRI-1/ GR-3 } \\
\text { HRI-2/ GR-9 }\end{array}$ & $\begin{array}{l}332.5(1,019) \\
580.3(1,904)\end{array}$ & $\begin{array}{c}0(0.0) \\
274.3(900)\end{array}$ \\
\hline $\begin{array}{l}{ }^{*} \text { Epithermal Neutron/Density/ } \\
\text { Gamma Ray }\end{array}$ & $\begin{array}{l}\text { Total water content / rock porosity / } \\
\text { stratigraphic correlation/borehole } \\
\text { conditions }\end{array}$ & $\begin{array}{l}\text { Halliburton } \\
\text { Energy } \\
\text { Services }\end{array}$ & $\begin{array}{l}10 / 22 / 2002 \\
10 / 29 / 2002\end{array}$ & $\begin{array}{l}\text { DSEN-1/ SDL-1/ GR-4 } \\
\text { DSEN-2/ SDL-2/ GR-10 }\end{array}$ & $\begin{array}{l}329.2(1,080) \\
580.6(1,905)\end{array}$ & $\begin{array}{c}0.0(0.0) \\
274.3(900)\end{array}$ \\
\hline Electric Micro Imager & $\begin{array}{l}\text { Saturated zone: lithologic } \\
\text { characterization, fracture and void } \\
\text { analysis. }\end{array}$ & $\begin{array}{l}\text { Halliburton } \\
\text { Energy } \\
\text { Services }\end{array}$ & $10 / 29 / 2002$ & $\begin{array}{l}\text { EMI-3/ CA6-3/ } \\
\text { SGR-3/ GR-8 }\end{array}$ & $581.3(1,907)$ & $274.3(900)$ \\
\hline Temperature/Gamma Ray & $\begin{array}{l}\text { Saturated zone: groundwater } \\
\text { temperature / stratigraphic } \\
\text { correlation }\end{array}$ & $\begin{array}{l}\text { Halliburton } \\
\text { Energy } \\
\text { Services }\end{array}$ & $\begin{array}{l}10 / 19 / 2002 \\
10 / 20 / 2002 \\
10 / 29 / 2002\end{array}$ & $\begin{array}{l}\text { TL-1/ GR-1 } \\
\text { TL-2/ GR-2 } \\
\text { TL-3/ GR-7 }\end{array}$ & $\begin{array}{l}328.3(1,077) \\
356.0(1,168) \\
569.7(1,869)\end{array}$ & $\begin{array}{c}15.2(50) \\
0.0(0.0) \\
274.3(900)\end{array}$ \\
\hline $\begin{array}{l}\text { Wireline Rotary Sidewall Coring Tool/ } \\
\text { Gamma Ray }\end{array}$ & Geologic samples & $\begin{array}{c}\text { Halliburton } \\
\text { Energy } \\
\text { Services }\end{array}$ & $10 / 30 / 2002$ & RSWC-1/ GR-5 & $574.9(1,886)$ & $333.1(1,093)$ \\
\hline
\end{tabular}

a Logs presented in geophysical log summary, Appendix D, are indicated by *.

b Depth below ground surface. 
This page intentionally left blank. 


\subsection{Geology and Hydrogeology}

\subsection{Introduction}

This section summarizes the geology and hydrogeology of Well ER-8-1. The basis for the discussion in Section 4.0 is the detailed lithologic log presented in Appendix C. The detailed lithologic log was developed using drill cuttings and sidewall core samples, geophysical logs, and drilling parameters. Results from petrographic, mineralogic, and chemical analyses provided by G. WoldeGabriel (LANL) for select lithologic samples (WoldeGabriel et al., 2003) were incorporated into the log.

\subsection{Geology}

This section is subdivided into discussions of the stratigraphic section and structural features interpreted from Well ER-8-1 data, followed by a discussion of alteration noted in samples from the well. The geologic setting for the Yucca Flat area is summarized in Gonzales and Drellack (1999).

Virtually no deep geologic or hydrologic data are available for this complex and hydrologically important area of Yucca Flat. A viable interpretation for this area in the draft hydrostratigraphic framework model for Yucca Flat (Gonzales and Drellack, 1999) shows a hydrogeologic barrier around the north end of the valley consisting of Precambrian quartzite (lower clastic confining unit) in the northeast, Climax granite due north, and rocks of the Eleana Formation and Chainman Shale (upper clastic confining unit) in the northwest.

\subsubsection{Geologic Setting}

Well ER-8-1 is at the extreme northern end of Yucca Flat, a hydrographically closed basin that is bounded on all sides by low hills and ranges of volcanic and sedimentary rocks (Figure 4-1). The subsurface stratigraphy of the Yucca Flat basin is dominated by Tertiary-age volcanic rocks consisting mainly of ash-flow tuffs with interbedded nonwelded and bedded tuffs, which are overlain by younger alluvial sediment eroded from the surrounding mountains.

The Mesozoic Era is represented only by intrusive igneous rocks in the NTS area. Cretaceous-age granitic rocks are exposed at Climax Mine north-northwest of the Well ER-8-1 site (Figure 4-2) and at Gold Meadows north of Rainier Mesa (Figure 4-1). The Gold Meadows intrusive and the Climax stock, which are about $12.9 \mathrm{~km}(8 \mathrm{mi}$.) apart at the surface, are probably related in both source and 
This page intentionally left blank. 


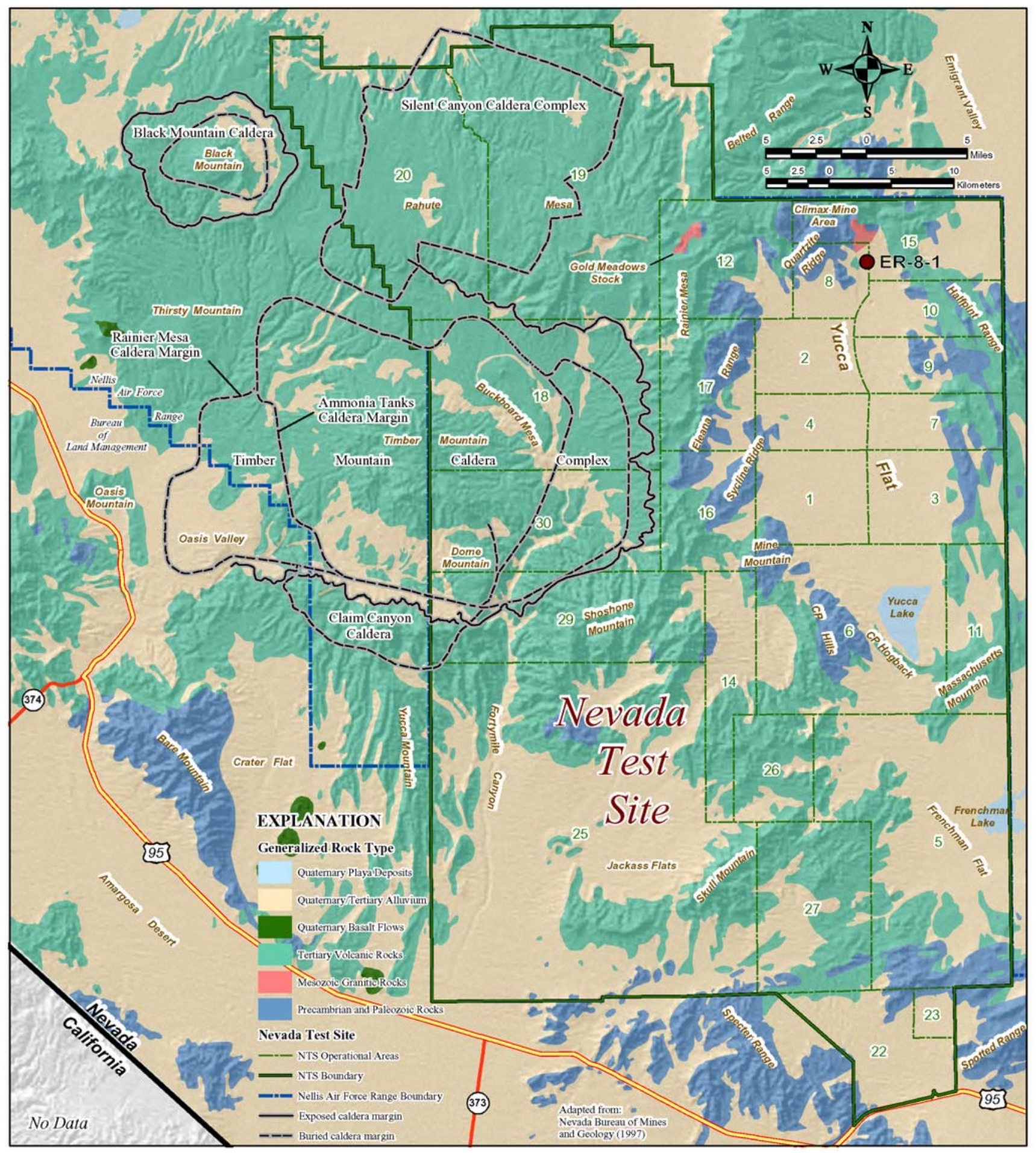

Figure 4-1

Generalized Surface Geologic Map of the Nevada Test Site Area Showing Location of Well ER-8-1 
This page intentionally left blank. 


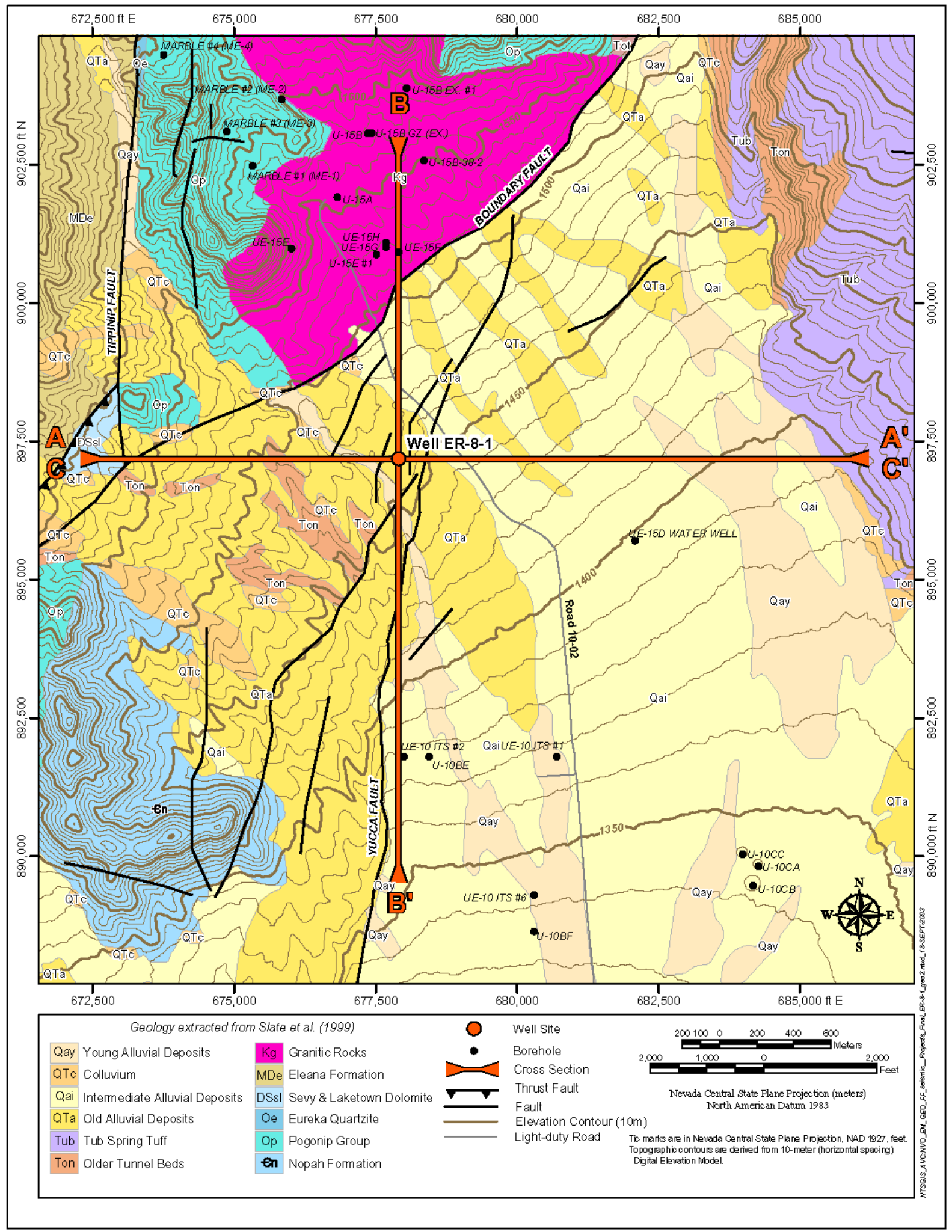

Figure 4-2

Surface Geologic Map of the Well ER-8-1 Site 
This page intentionally left blank. 
time, and are believed to be connected at depth (Jachens, 1999; Blouin et al., 2003). The Climax stock is a composite granitic intrusive body comprising an older, medium-grained, equigranular granodiorite and a younger, fine- to medium-grained, coarsely porphyritic quartz monzonite (Orkild et al., 1983). Recent re-analysis of magnetic data by Jachens (1999) reaffirmed the general geometry and connection at depth of the Climax and Gold Meadows stocks. The Climax stock and Gold Meadows intrusives are grouped into the Mesozoic granite confining unit, the surface exposure of which is shown on Figure 4-1. These granitic bodies are considered to be a confining unit because of their low intergranular porosity and permeability, and the lack of inter-connecting fractures (Walker, 1962; Murray, 1981; and Laczniak et al., 1996).

In the Yucca Flat area the rocks are cut by north-south-trending, mostly down-to-the-east, high-angle normal faults (e.g., Yucca and Topgallant faults) related to Basin and Range extension (Byers et al., 1976). The Oak Spring geologic quadrangle map (Barnes et al., 1963) depicts the surface geology in the vicinity of Well ER-8-1.

\subsubsection{Stratigraphy and Structure}

The stratigraphy and lithology of Well ER-8-1 are illustrated in Figure 4-3. No samples were collected

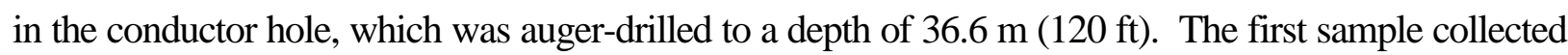
below the conductor casing was of alluvium, indicating that the auger hole did not penetrate into the volcanic tuffs. The tuff/alluvium contact is tentatively set at $42.7 \mathrm{~m}(140 \mathrm{ft})$. Immediately below the alluvial deposits are $291.4 \mathrm{~m}$ (956 ft) of bedded tuffs related to units of the Volcanics of Oak Spring Butte Group, including Tunnel bed 2, Yucca Flat Tuff, Tunnel bed 1, Redrock Valley Tuff, tuff of Twin Peaks, and tuff of Whiterock Spring (Ferguson et al., 1994). Stratigraphic identification of these older tuffs could not confidently be made with the typical binocular microscope examination, and are tentatively based on data from WoldeGabriel et al. (2003) for 22 samples from the borehole (Table 3-2). The volcanic stratigraphy presented here for Well ER-8-1 is consistent with that identified in the closest boreholes (Warren et al., 2000).

An interval of zeolitic tuffs with abundant, diverse lithic fragments, including some from the Eleana Formation, was logged between 298.7 and $334.1 \mathrm{~m}$ (980 - 1,096 ft). This section directly overlies the Paleozoic-age carbonate rocks, and stratigraphically represents undifferentiated Older Tuffs. Persistent sloughing and borehole enlargement occurred in the lower portion of this interval. 
This page intentionally left blank. 


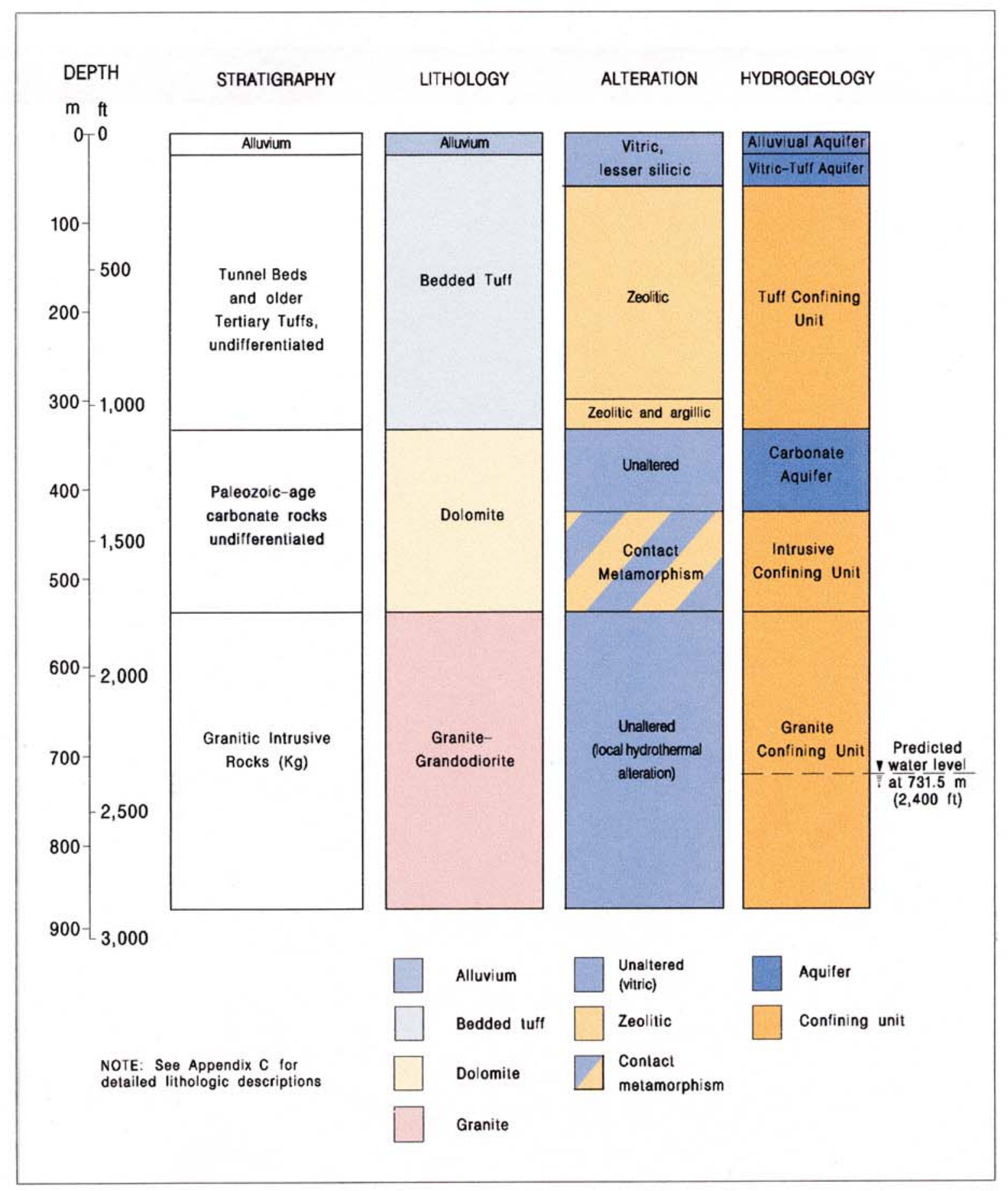

Figure 4-3

Geology and Hydrogeology of Well ER-8-1 
This page intentionally left blank. 
Undifferentiated dolomite of uncertain Paleozoic age was encountered at $334.1 \mathrm{~m}$ (1,096 ft). Based on nearby outcrops, the rocks at Well ER-8-1 are likely to be Ordovician or Cambrian in age (Barnes et al., 1963). Paleontological age dating of selected cuttings samples is pending. Several altered intrusive dikes were encountered in dolomite below the depth of about $442.0 \mathrm{~m}(1,450 \mathrm{ft})$. The degree of alteration of these dikes increases with depth and is related to the underlying granitic intrusive.

Granite was unexpectedly encountered at the depth of $538.9 \mathrm{~m}(1,768 \mathrm{ft})$, and the borehole penetrated granite to the TD of $872.6 \mathrm{~m}$ (2,863 ft). Comparison of the mineralogy and relative mineral abundances with data for Climax stock (Maldonado, 1977; Naiser and Maldonado, 1981) indicate that the rock is granodiorite, from the Cretaceous-age Climax stock located to the northwest of the Well ER-8-1 site.

The position, extent, and thickness of the stratigraphic units near Well ER-8-1 are illustrated on the geologic cross sections in Figures 4-4 and 4-5. As shown on the north-south cross section (Figure 4-5), Well ER-8-1 is interpreted to be located near the southern edge of the granitic body. This interpretation is based on data from nearby drill holes as well as from regional analyses of surface geology, gravity, and magnetic data (Orkild et al., 1983; Cole et al., 1997; Gonzales and Drellack, 1999; Phelps et al., 1999; and Jachens, 1999). Well ER-8-1 is believed to have crossed a fault zone at the depth of 732 to $762 \mathrm{~m}$ (2,400 to $2,500 \mathrm{ft})$, where drill cuttings samples indicate highly altered rocks. Though the affected granite is probably well fractured, little or no additional formation water was produced when that interval was drilled.

\subsubsection{Alteration}

Alteration has a significant effect on both the general hydraulic character of volcanic rocks and on how radionuclides migrate through these rocks. Mineralogical analysis reveals two types of pervasive alteration processes at Well ER-8-1. Low temperature zeolitic alteration is dominant in the lower twothirds of the volcanic section. The carbonate rocks closest to the granitic stock display a mineral assemblage that is hydrothermal in origin. The predominant type of mineralogic alteration observed in each stratigraphic unit encountered in Well ER-8-1 is illustrated on Figure 4-3.

Above the depth of about $61 \mathrm{~m}$ (200 ft) the tuffs are mostly unaltered (vitric), with some silicic alteration. Between 61 and $91 \mathrm{~m}$ (200 to $300 \mathrm{ft}$ ) is a transition to the pervasively zeolitized rocks below. This zone of zeolitic alteration is dominated by clinoptilolite, with lesser amounts of mordenite, opal-CT, smectite, and cristobalite. 


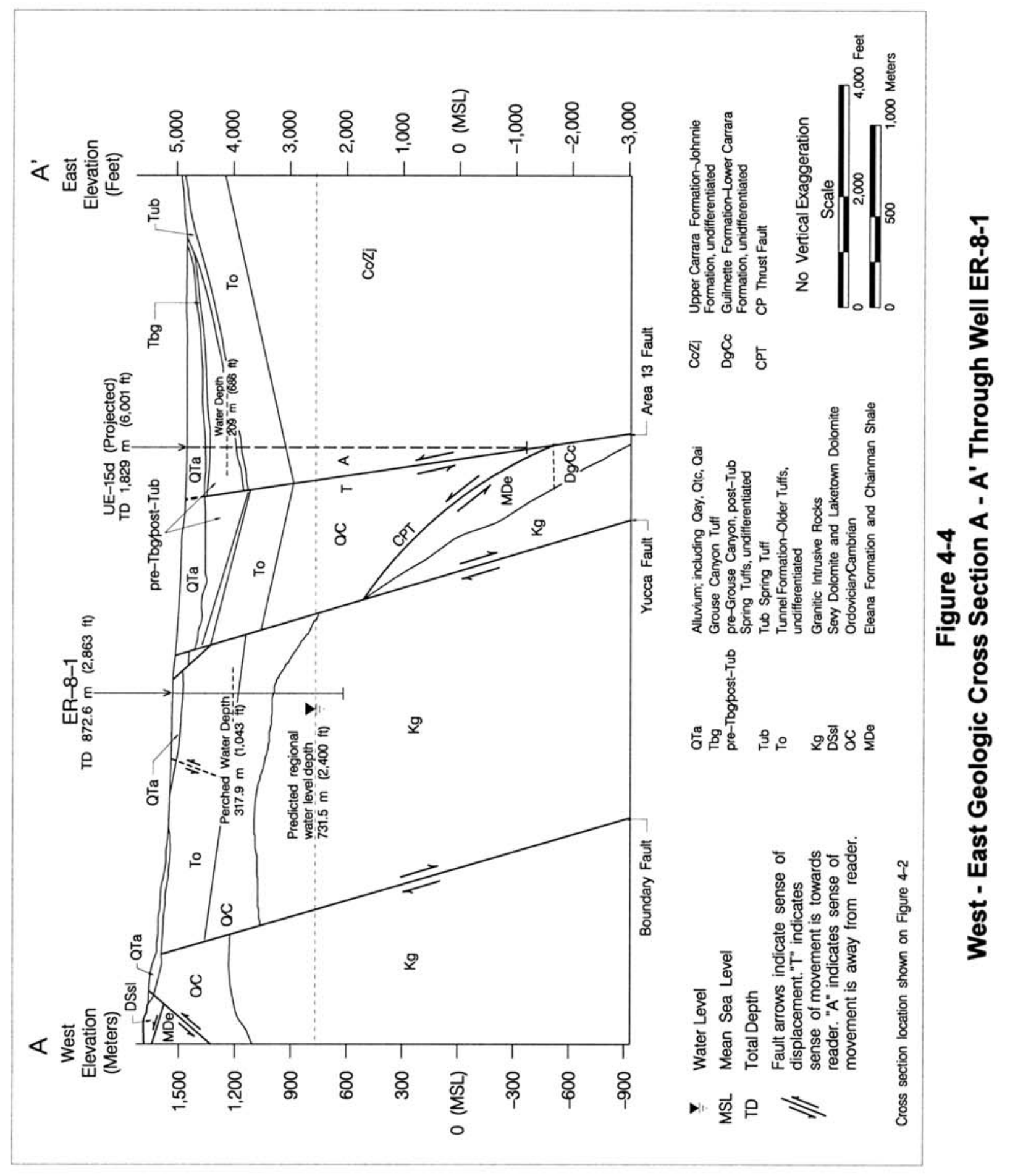




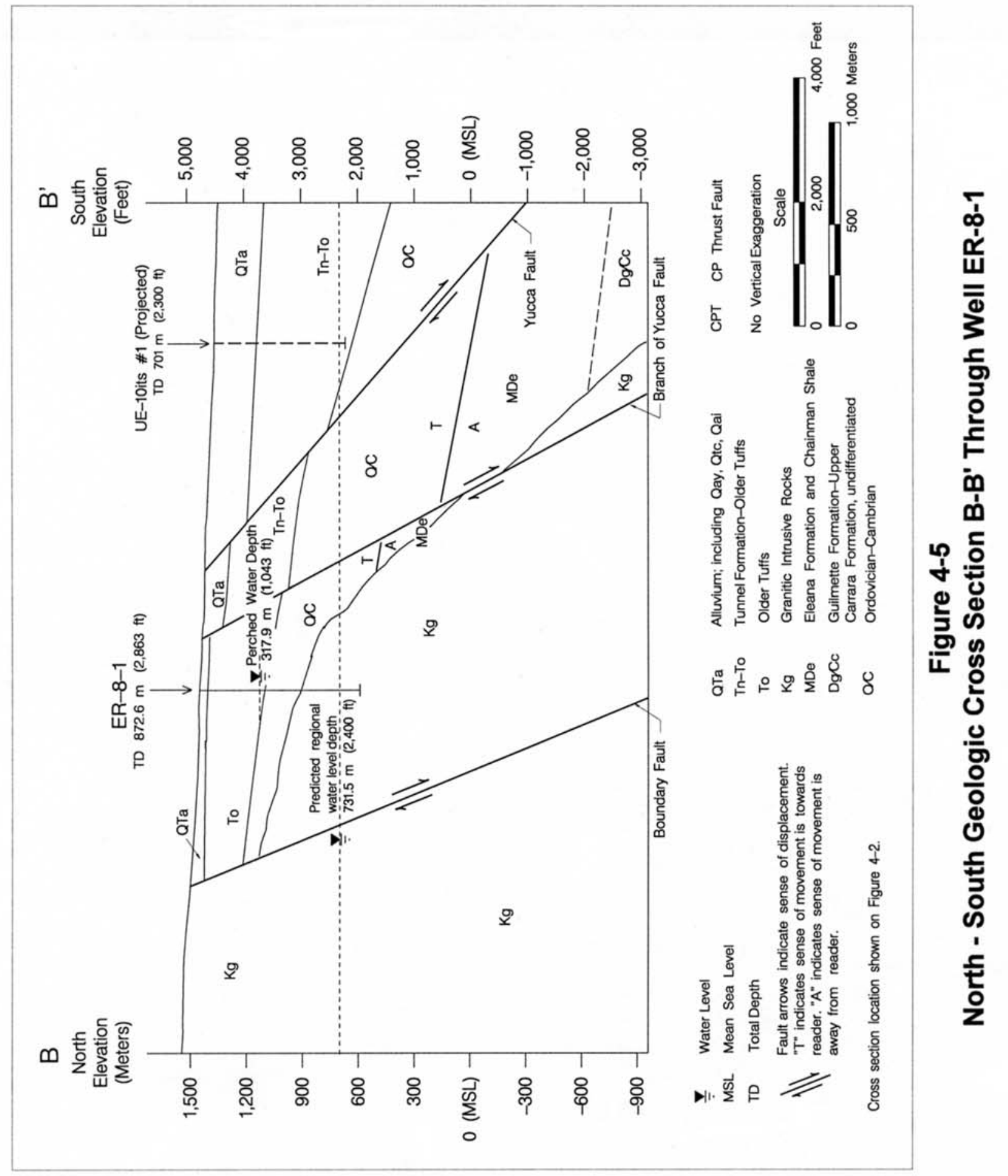


The carbonate rocks below $442.0 \mathrm{~m}(1,450 \mathrm{ft})$ exhibit increasing alteration as a result of heat and invasive fluids from the underlying granite intrusive (e.g., contact metamorphism and dike intrusion). Alteration products include smectite, illite, and minor amounts of cristobalite, chlorite and calcite. Pyrite is also present. At greater depths the dolomite is altered to marble and is cut by numerous fractures and altered (argillic) intrusive dikes. Closer to the contact with the granite the carbonate rocks maybe classified as skarn, as copper and other types of mineralization are present. The fault zone at 732 to $762 \mathrm{~m}(2,400$ to $2,500 \mathrm{ft})$ is also altered, and drill cuttings from this depth interval included clayey gauge material. As mentioned above, the zone apparently yielded no additional water when drilled, indicating that the clayey fault gauge and/or fracture filling effectively closes the fractures.

\subsection{Predicted versus Actual Geology}

The predicted geology for Well ER-8-1 (IT, 2002a) was based on surface geologic maps by Slate et al. (1999) and Barnes et al. (1963). The geology of nearby wells UE-10 ITS\#1, UE-10j and UE-15d Water Well (Figure 1-2) was also evaluated for possible lithologic and structural similarities. In addition, information from Jachens (1999) was used to incorporate the latest interpretation of the subsurface extent and geometry of the granite intrusive rocks of northern Yucca Flat. A comparison of the predicted and the actual stratigraphy is provided in Figure 4-6.

The well was predicted to penetrate approximately $61.0 \mathrm{~m}$ (200 ft) of tuffaceous alluvium, overlying about $182.9 \mathrm{~m}(600 \mathrm{ft})$ of Tertiary-age tuffs. Beneath the volcanic rocks the well was predicted to penetrate about $213.4 \mathrm{~m}$ (700 ft) of Paleozoic-age carbonate rocks thrust over the younger Mississippian-age Eleana Formation and Chainman Shale. These fine-grained clastic rocks were expected to be about $457.2 \mathrm{~m}$ (1,500 ft) thick and stratigraphically overlie the Devonian-age, mostly carbonate, Guilmette Formation. The Cretaceous-age granite intrusive was predicted to be below about 1,524.0 m (5,000 ft) depth at the Well ER-8-1 site.

Well ER-8-1 penetrated about $42.7 \mathrm{~m}$ (140 ft) of tuffaceous alluvium and $291.4 \mathrm{~m}$ (956 ft) of Tertiaryage tuff. The Paleozoic-age carbonate rocks were encountered at the depth of $334.1 \mathrm{~m}(1,096 \mathrm{ft})$, $90.2 \mathrm{~m}$ (296 ft) deeper than expected. Such departures from pre-drill predictions at a remote site are not unexpected. But, instead of penetrating the Eleana Formation at $457.2 \mathrm{~m}$ (1,500 ft) as predicted, Well ER-8-1 encountered granitic rocks at $538.9 \mathrm{~m}$ (1,768 ft). This was a significant departure from the expected geology. Based on the inferred displacement of the Boundary fault (Houser and Poole, 1960) and the analysis of aeromagnetic data (Jachens, 1999), depth to granite at the Well ER-8-1 site 


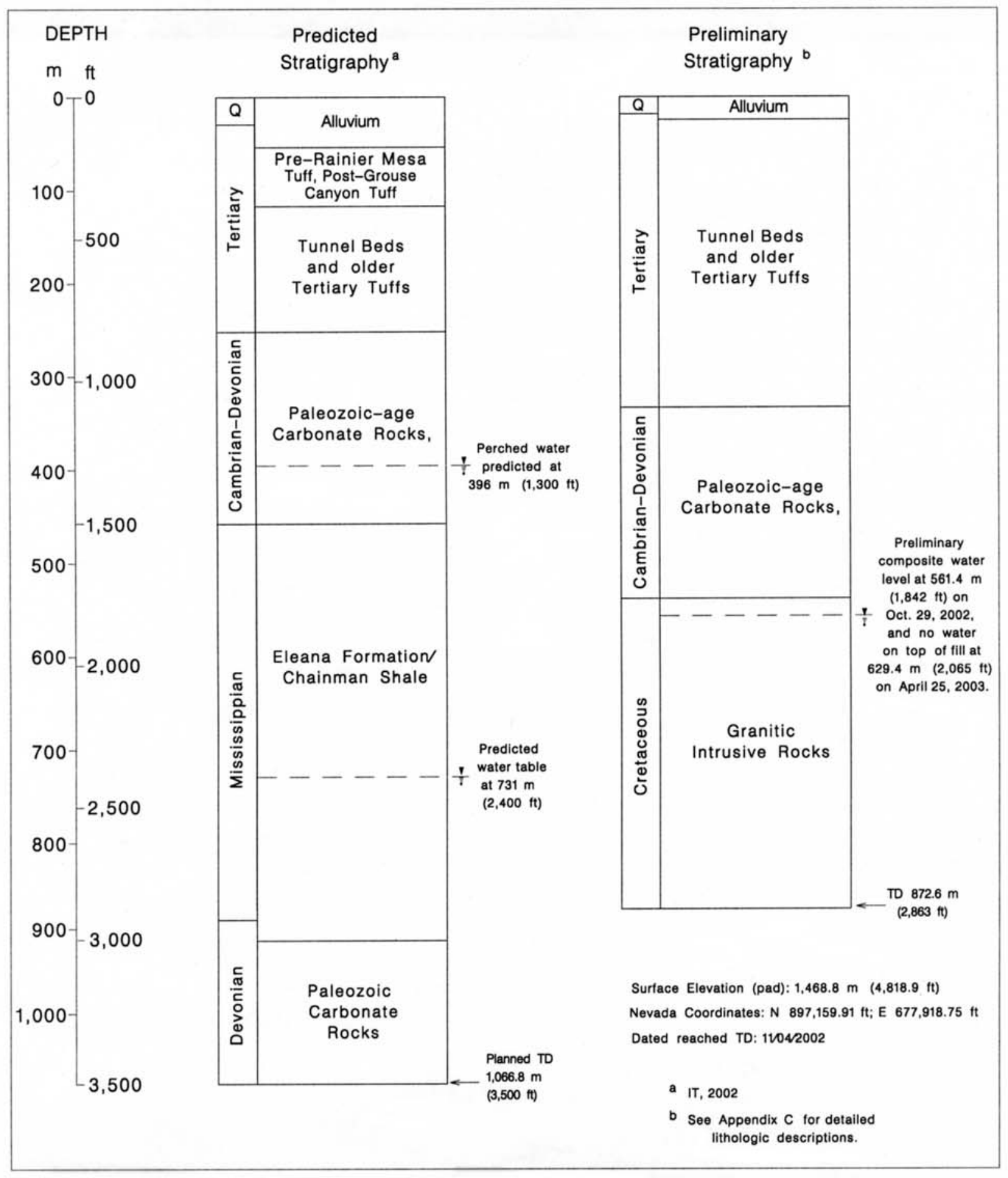

Figure 4-6

Predicted and Actual Stratigraphy at Well ER-8-1 
prior to drilling was expected to be greater than $1,524.0 \mathrm{~m}(5,000 \mathrm{ft})$. The aeromagnetic data must be reassessed in light of this new subsurface tag, and the analytical model modified accordingly.

\subsection{Hydrogeology}

The hydrogeologic framework for Yucca Flat is built upon that established for the NTS area by Winograd and Thordarson (1975). Laczniak et al. (1996) provides a summary of the hydrogeologic framework. The hydrostratigraphic framework used to construct preliminary hydrogeologic models for the Yucca Flat area was further developed by the UGTA hydrogeologic modeling team (Gonzales et al., 1998; Gonzales and Drellack, 1999).

An interpretation of the possible distribution of hydrogeologic units at Well ER-8-1 is shown in cross section on Figure 4-7. Because of the limited amount of data from the area around Well ER-8-1, and the difficulty in predicting the lateral continuity of hydraulic properties of volcanic rocks, the cross section is rather conjectural. However, it does illustrate the complexities associated with the distribution of hydrogeologic units in highly faulted, extensional settings such as the extreme northern Yucca Flat area.

The rocks of Well ER-8-1 can be subdivided into hydrogeologic units, as illustrated in Figure 4-3. All of the Quaternary and Tertiary rocks encountered in the upper $334.1 \mathrm{~m}(1,096 \mathrm{ft})$ of the borehole are assigned to just three HSUs: the alluvial aquifer, the Timber Mountain lower vitric tuff aquifer, and the Yucca Flat lower confining unit.

To develop the pre-Tertiary hydrostratigraphic framework for this area, various blocks of Paleozoicage sedimentary rocks have been defined as HSUs on the basis of their hydrogeologic character and their extent and thickness. The allochthonous (i.e, thrust-faulted) Middle Devonian through Middle Cambrian carbonate rocks in the upper plates of Mesozoic thrust faults such as the Belted Range and CP faults are assigned to the lower carbonate aquifer - thrust sheet (LCA3). The UCCU consists of Mississippian and Upper Devonian siliciclastic rocks that are represented in the Yucca Flat vicinity by the Chainman Shale and Eleana Formation. The LCA consists of autochthonous (i.e., not thrustfaulted) Middle Devonian through Middle Cambrian carbonate rocks. Neither UCCU clastic rocks nor LCA carbonate rocks were encountered at this site. On the basis of pre-Tertiary sub-crop data (Cole and Cashman, 1998; Cole et al., 1997; Cole, 1997) and in agreement with the conceptual model of Gonzales and Drellack (1999), the carbonate rocks at Well ER-8-1 are interpreted to be LCA3. 


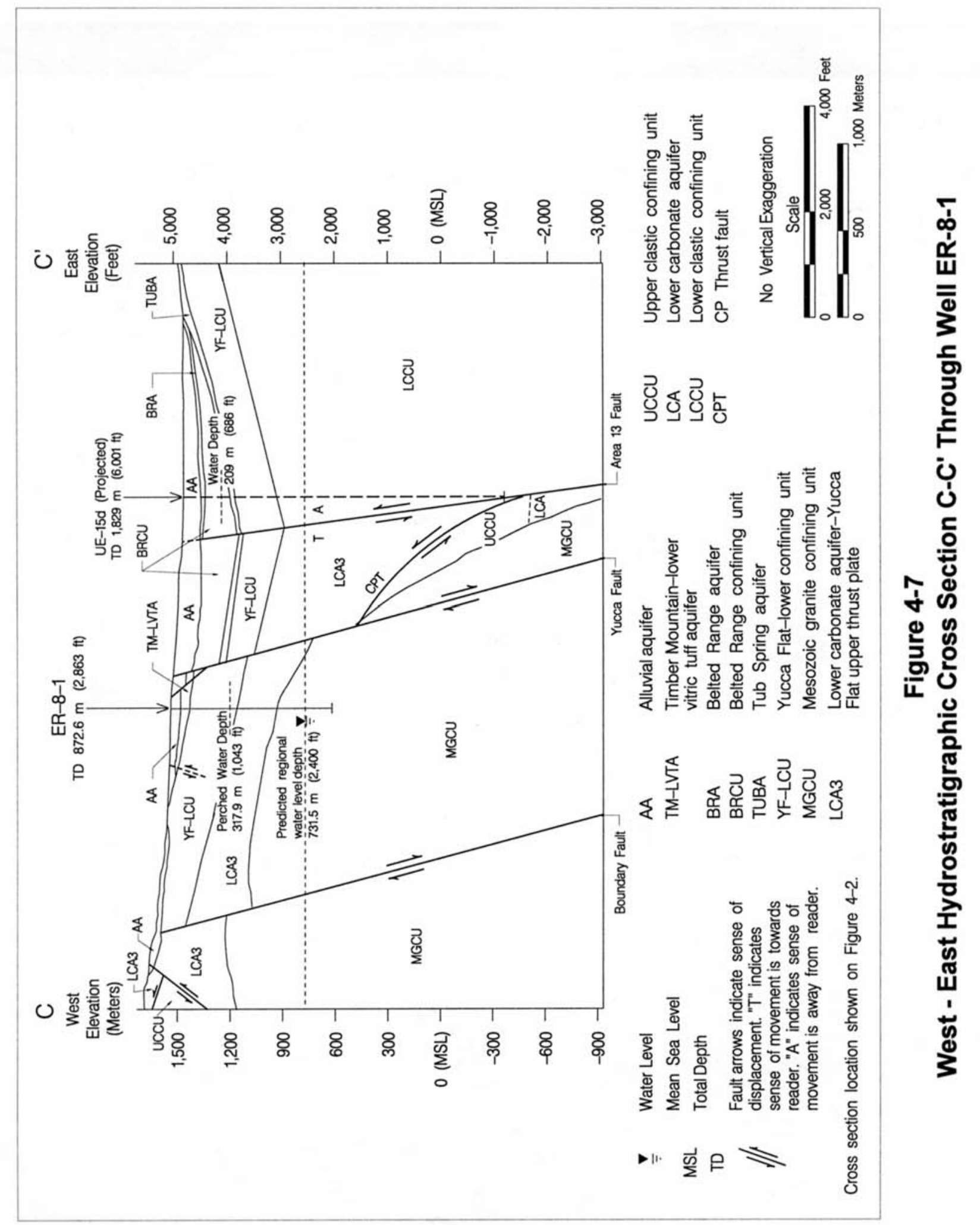


The dominant hydrogeologic unit in Well ER-8-1 is granite confining unit (Cretaceous System of the Mesozoic Era). Physical properties, including hydraulic properties, for the Climax granite stock are summarized in Blouin et al. (2003).

Analysis of water production data during drilling indicates that the granite confining unit produced very little water, at a rate of about 0 to $114 \mathrm{lpm}$ (0 to $30 \mathrm{gpm}$ ) (Appendix A-1). This reaffirms previous indications that these rocks have very low hydraulic conductivity. Observations during mining at Climax suggests that water production from the granite is confined to discrete fractured intervals. However, much of the water produced at Climax was determined to be perched and not necessarily connected to the regional aquifer (Walker, 1962). Thus, data from Well ER-8-1 confirm that interconnectivity of the fractures is poor. The fault zone encountered in the interval 731.5 to $762.0 \mathrm{~m} \mathrm{(2,400} \mathrm{to} \mathrm{2,500} \mathrm{ft)} \mathrm{may}$ be a zone of enhanced conductivity, as evidenced by the loss of drilling fluid to the formation in this interval. However, little additional water was produced while drilling this interval.

It should also be noted that the dolomite overlying the granite intrusive is altered and intruded with dikes. These carbonate rocks, though typically categorized as an aquifer, are probably impermeable in the vicinity of the granite body.

See the discussion of the general hydraulic properties of the hydrogeologic units expected in Well ER-8-1 in Section D.6.2 and Table D.6.1 of IT (2002a). Planned hydrologic testing in Well ER-8-1 may not be possible due to the low hydraulic conductivity of the rocks penetrated. 


\subsection{Hydrology}

\subsection{Preliminary Water-Level Information}

Water-level data are sparse in northern Yucca Flat, and the configuration of the potentiometric surface in extreme northern Yucca Flat is poorly known. Hydrologic data from Well ER-8-1 will be an important to aid in understanding regional groundwater flow into Yucca Flat.

As reported in Hale et al. (1995), the elevation of the static water level (SWL) in the Belted Range/Emigrant Valley area to the north and northeast of this site (e.g., at Well UE-13a - see location on Figure 1-2), is 1,336.5 m (4,385 ft). However, in most of Yucca Flat (e.g., at Well UE-10j) the SWL elevation is about $732 \mathrm{~m}(2,400 \mathrm{ft})$ (IT, 1996). This difference in SWL elevation implies a steep groundwater gradient through the area of the Climax stock and Paiute Ridge anticline (largely preCambrian quartzite). No holes have been drilled deep enough in Climax stock to intercept the regional water table. Only small amounts of perched water were encountered in the granite tunnels constructed for the three nuclear tests there, and well data from the immediate Climax stock area produced varying depths to the SWL (IT, 1996).

These data lead to the conclusion that the granitic intrusive stock and the surrounding Precambrian/Paleozoic-age silicic clastic rocks act as a barrier to groundwater flow in this region, which can be conceptualized as a southeast-northwest-trending barrier rimming the north end of Yucca Flat. This barrier extends from Precambrian sedimentary rocks of the lower clastic confining unit exposed in the Paiute Ridge anticline southeast of the Well ER-8-1 site, includes the Climax stock, and continues west to the Gold Meadows stock north of Rainier Mesa (IT, 1996; Gonzales et al., 1999). Thick sections of Chainman Shale and Eleana Formation west of Climax stock and continuing southwest may also contribute to this hydrologic barrier. Well ER-8-1 is located south of the barrier.

The elevation of the water table at Well ER-8-1 was projected to be approximately $731.5 \mathrm{~m}(2,400 \mathrm{ft})$, as derived from sparse hydrologic data for this region (IT, 1996). Based on the pre-construction estimate of surface elevation at the site, depth to the regional water table was expected at the depth of approximately $737.6 \mathrm{~m}$ (2,420 ft) (IT, 2002a). A preliminary composite fluid level at Well ER-8-1 was determined from geophysical logs to be at the depth of $556.0 \mathrm{~m}(1,824 \mathrm{ft})$ on October 29, 2002, while the borehole was at a temporary TD of $652.6 \mathrm{~m}(2,141 \mathrm{ft})$. This depth is between the predicted perched and regional water levels. However, on April 25, 2003, no fluid was detected in the open borehole to top of fill at a depth of $629.4 \mathrm{~m}$ 
$(2,065 \mathrm{ft})$. The initial standing water in the hole (measured at $556 \mathrm{~m}$ [1,824 ft] on October 29, 2002) may or may not represent a real potentiometric surface for a perched water zone. Additional data need to be collected; however a piezometer for monitoring of the water level was not installed at the time work at Well ER-8-1 was suspended.

\subsection{Water Production}

Water production was estimated during drilling of Well ER-8-1 on the basis of LiBr dilution data as measured by Shaw field personnel. The water production rate while drilling Well ER-8-1 remained relatively low. Of the primary water-producing unit(s) at this location, the LCA3 is above the SWL and the LCA is not present (replaced by the granite intrusive mass). Estimated water production rates while drilling are presented graphically in Appendix A-1.

Based on the predicted geology for Well ER-8-1, a perched water zone was expected at the depth of about $396.2 \mathrm{~m}$ (1,300 ft), where the dolomite (aquifer) overlying rocks of the Eleana Formation and Chainman Shale (confining unit) could provide the hydrogeologic geometry for a perched water zone. Zeolitic tuffs at the NTS typically exhibit very low hydraulic conductivities and perched water above or within them is not uncommon. Measurable water production (approximately $114 \mathrm{lpm}$ [30 gpm]) was first noted at the depth of about $318 \mathrm{~m}(1,043 \mathrm{ft})$ within zeolitic bedded tuffs. This perched water zone was cased off as the borehole was advanced.

Water production while drilling the granite was generally less than about 19 lpm (5 gpm), though slightly more water (perhaps up to $38 \mathrm{lpm}$ [10 gpm]) may have been produced in the upper part of the granite above $640 \mathrm{~m}(2,100 \mathrm{ft})$ depth (Appendix A-1).

\subsection{Preliminary Flow Meter Data}

Flow meter data, along with temperature, electrical conductivity, and $\mathrm{pH}$ measurements, can be used to characterize borehole fluid variability, which may indicate inflow and outflow zones. These data are typically collected from UGTA wells before or after installation of the completion string. However, flow meter data were not collected at Well ER-8-1 due to the early termination of drilling, and because a completion string was not installed as planned (see Section 7.0).

\subsection{Preliminary Groundwater Characterization Samples}

Preliminary groundwater characterization samples are typically collected UGTA wells following geophysical logging. However, because of lack of credible formation water no preliminary groundwater samples were collected at Well ER-8-1. 


\subsection{Precompletion and Open-Hole Development}

As noted elsewhere in this document, Well ER-8-1 has not been completed due to excessive hole sloughing. To date, there has been no precompletion development at Well ER-8-1.

For future reference it should be noted that approximately 310,025 liters (1,950 barrels [81,900 gal]) of 60-70 viscosity bentonite drilling mud were pumped down-hole in the effort to free the stuck drill pipe (Section 2.3). Not all of this fluid was circulated out of the borehole and undoubtedly, some remains within the fill material and in the formation. 
This page intentionally left blank. 


\subsection{Well Completion}

\subsection{Introduction}

Well completion refers to the installation in a borehole of a string of tubing or casing that is slotted or screened at one or more locations along its length. The completion process also typically includes emplacement of backfill materials around the casing, with coarse fill such as gravel adjacent to the open intervals and impervious materials such as cement between, or above, the open intervals to isolate them. The casing serves as a conduit for insertion of a pump in the well, for inserting devices for measuring fluid level, and for sampling, so that accurate potentiometric and water chemistry data can be collected from known portions of the borehole.

The original planned well completion design as proposed in the Yucca Flat Drilling Criteria (IT, 2002a) is summarized in Section 7.2.1, and a new proposed well completion based on the hydrogeology encountered is described in Section 7.2.3.

\subsection{Well Completion Design}

As noted elsewhere in this document, Well ER-8-1 was not completed due to excessive hole sloughing.

\subsubsection{Planned Completion Design}

The original completion design (presented in IT, 2002a) was based on the assumption that Well ER-8-1 would penetrate perched water within the LCA3 (above rocks of the Eleana Formation and Chainman Shale [UCCU]), and ultimately the regional water table in the LCA (below the UCCU). Refer to Figure D.6-1 in IT (2002a).

The well was planned to be completed with a single casing string consisting of $51 \frac{1}{2}$-in. stainless steel casing, with every other joint slotted, suspended on carbon-steel $7 e$-in. casing. The primary goal was to obtain satisfactory completion within the LCA, but the proposed completion design also called for the isolation (using non-slotted ["blank"] casing) of low transmissivity zones within the completion interval, if such zones can be identified. The perched water in the LCA3, if present, would be isolated and accessed via a $2 f$-in. stainless-steel piezometer tube run in the 44.5-cm (17.5-in.) diameter borehole, outside the 13d -in. surface casing (refer to Figure D.7-1 in IT, 2002a). 


\subsubsection{As-Built Completion Design}

Because of persistent hole sloughing and bridging, completion of the ER-8-1 borehole was suspended, and the borehole was abandoned in the configuration shown in Figure 7-1. An as-built wellhead diagram is provided in Figure 7-2. The casing materials used to date in Well ER-8-1 are listed in Appendix A-2. The fill was last tagged at $629.4 \mathrm{~m}$ (2,065 ft) on April 25, 2003, at which time the hole was found to be dry.

\subsubsection{Proposed Completion Design for Unfinished Well ER-8-1}

The new proposed completion design for Well ER-8-1 is based on evaluations of lithology, water production, drilling data (lost circulation, etc.), and data from various geophysical logs. The proposed design would provide access to the granite confining unit via a piezometer tube (Figure 7-3).

The proposed composition of the string summarized here is detailed on Table 7-1. The lower section of the completion string, below the regional water table (projected to be at the depth here of about $731.5 \mathrm{~m}[2,400 \mathrm{ft}])$, should be stainless-steel, slotted $2 \mathrm{f}$-in. tubing. The bottom of the slotted tubing should be placed deeper than $792.5 \mathrm{~m}(2,600 \mathrm{ft})$ to provide about $61.0 \mathrm{~m}(200 \mathrm{ft})$ submergence below the projected regional water table. The bottom of the $2 f$-in. tubing may be a blank bull-nose to serve as a sediment sump or may be open-ended. The tubing above $731.5 \mathrm{~m}(2,400 \mathrm{ft})$ should be blank and may be carbon steel.

\subsubsection{Rationale for Differences between Original Planned and New Proposed Well Design}

Based on the pre-drilling expectations of the hydrogeology of Well ER-8-1, the original planned well design included the construction of one completion zone in the LCA and a piezometer that accesses a perched water zone in the LCA3. However, the geology encountered at Well ER-8-1 was much different than expected. The UCCU was not encountered, no perched water was detected in the LCA3 carbonate rocks, and the target aquifer (LCA) was not present. Only a small amount of perched water was detected in the lower portion of the volcanic section. The Climax granitic intrusive mass (an aquitard) was encountered at a depth of $538.9 \mathrm{~m}(1,768 \mathrm{ft})$.

The planned completion design as presented in IT (2002a) must be modified to accommodate the low conductivity conditions encountered in Well ER-8-1. Low hydraulic conductivity precludes the planned hydraulic pumping and other tests. Obtaining measurements of depth to water and samples for water chemistry at Well ER-8-1 are still important. These data can be collected with the installation of a $2 f$-in. piezometer tube to below the projected regional water level. 


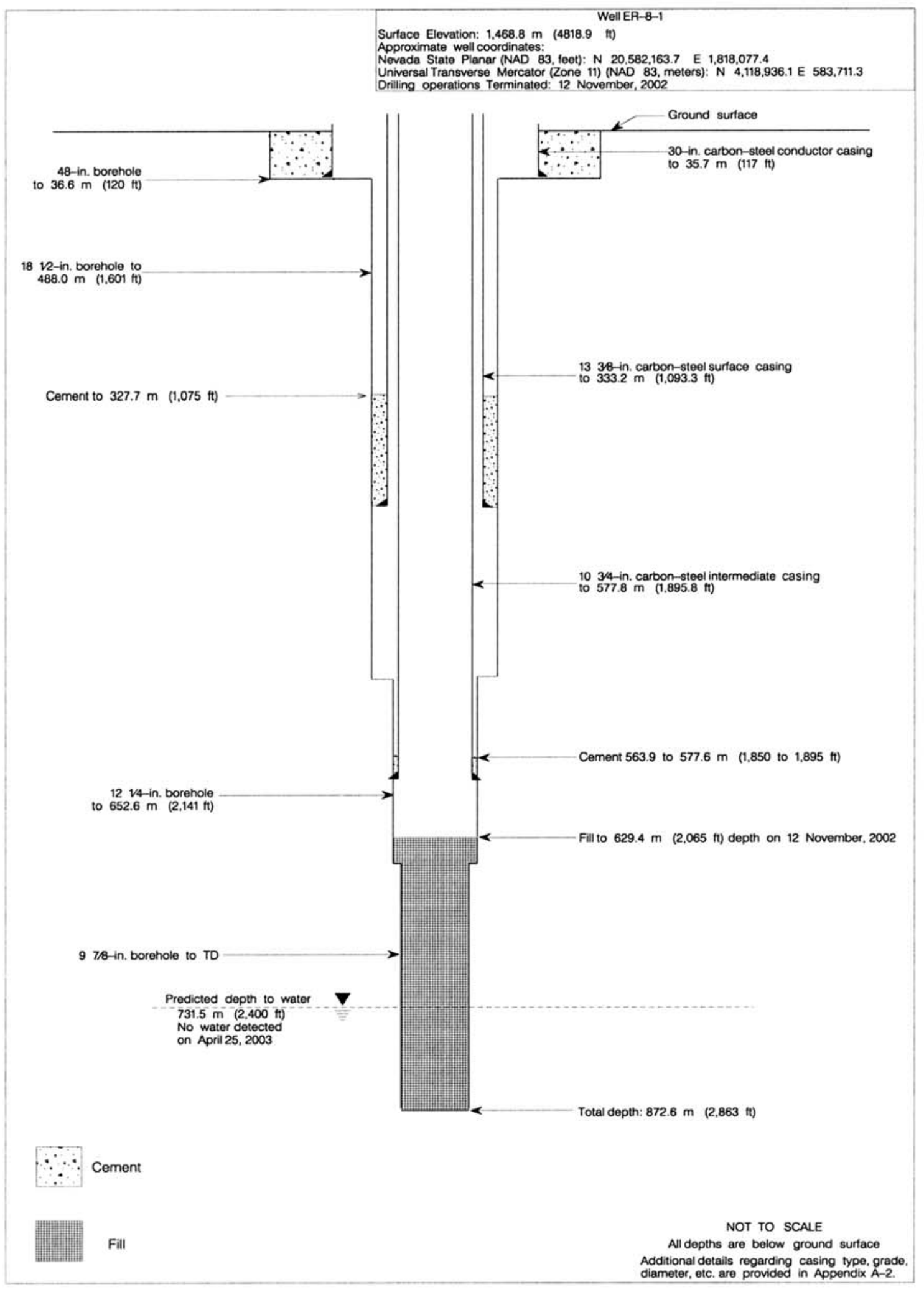

Figure 7-1

As-built Completion Schematic for Well ER-8-1, November 2002 


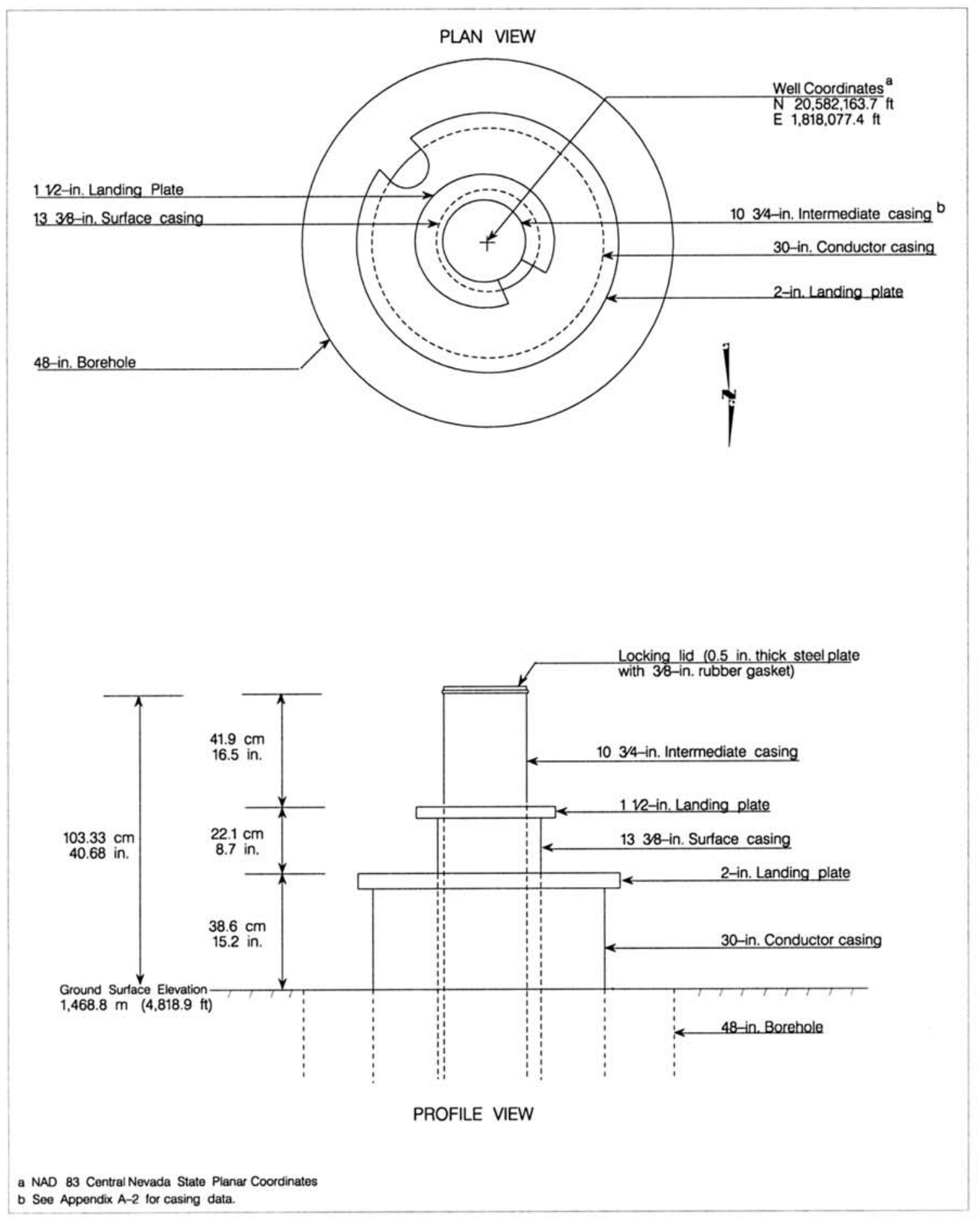

Figure 7-2

Wellhead Diagram for Well ER-8-1, November 2002 


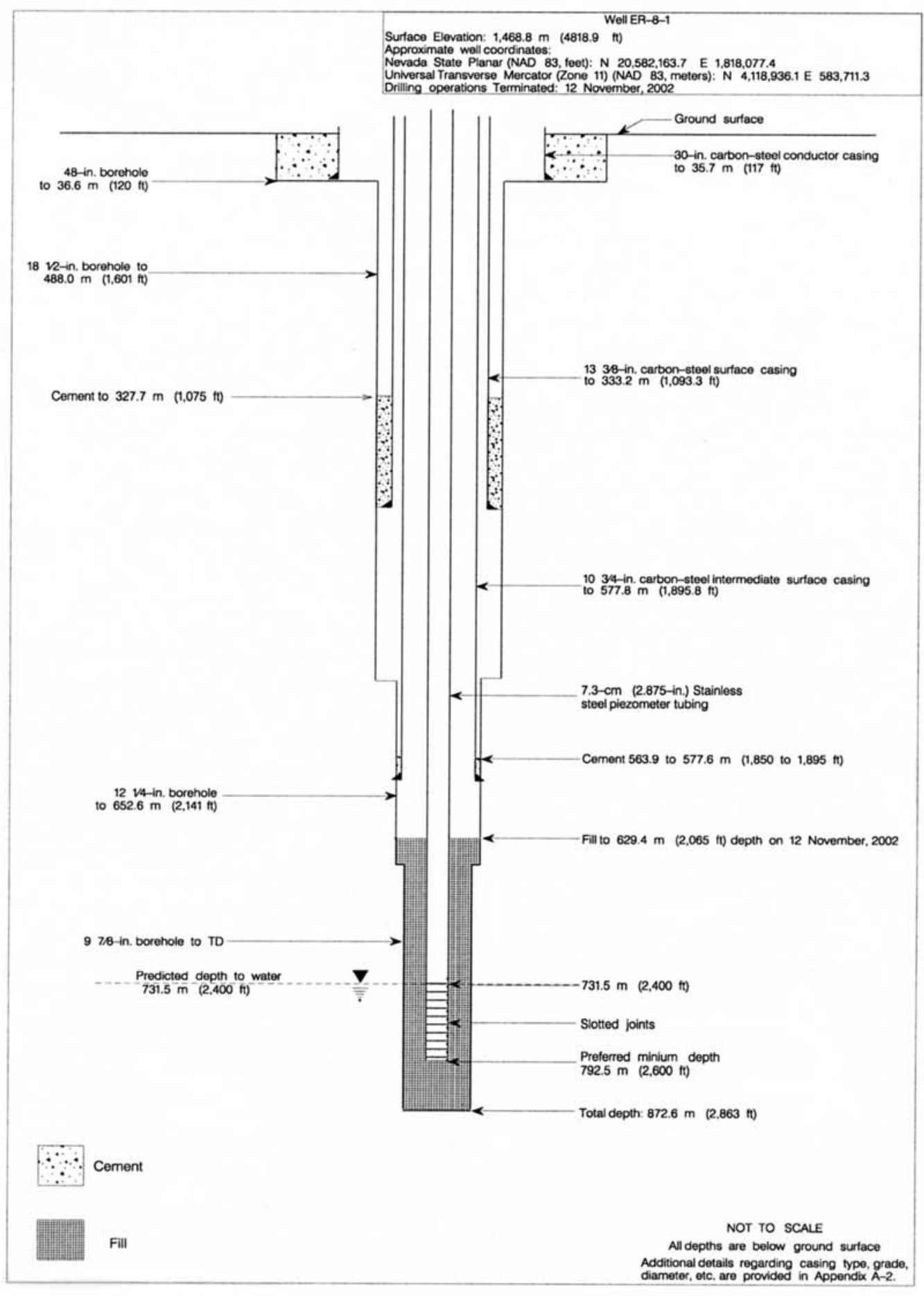

Figure 7-3

Proposed Completion Design for Well ER-8-1 
Table 7-1

Proposed Completion String Construction Summary for Well ER-8-1

\begin{tabular}{|c|c|c|c|c|}
\hline $\begin{array}{l}\text { Piezometer } \\
\text { Tubing Type }\end{array}$ & \multicolumn{2}{|c|}{$\begin{array}{l}\text { Configuration } \\
\text { meters (feet) }\end{array}$} & Cement & Sand/Gravel \\
\hline $\begin{array}{l}2 f \text {-inch carbon- } \\
\text { steel tubing }\end{array}$ & $\begin{array}{l}\text { Surface to } 731.5 \\
(2,400)\end{array}$ & Blank & Not necessary & Not necessary \\
\hline $\begin{array}{l}\text { 2f } \text {-inch stainless- } \\
\text { steel tubing }\end{array}$ & $\begin{array}{c}731 \text { to } 792.5 \text { (minimum) } \\
(2,400 \text { to } 2,600)\end{array}$ & Slotted joints & Not necessary & Not necessary \\
\hline
\end{tabular}




\subsection{Planned and Actual Costs and Scheduling}

The original BN cost model developed for Well ER-8-1 was based on drilling to the planned TD of $1,469.0 \mathrm{~m}(3,500 \mathrm{ft})$. The drilling program baseline projected that it would require 26 days to accomplish drilling of the surface and main holes, logging, and completion of the well, assuming the conductor hole would already have been constructed by BN. However, the actual conditions encountered during drilling (severe borehole instability) were measurably different from predicted conditions so the baseline was changed during drilling.

The new cost model is based on the planned TD but includes additional construction time to treat the unexpected borehole instability problems. The new schedule projected that it would require 41 days to drill and complete Well ER-8-1. However, because the borehole was terminated $194.2 \mathrm{~m}$ (637 ft) short of the planned TD and no completion string was installed, the actual time spent at Well ER-8-1 was 32 days. A graphical comparison, by day, of planned and actual well-construction activities is presented in Figure 8-1.

The cost analysis for Well ER-8-1 begins with construction of the conductor hole by BN and the cost of mobilizing the UDI drill rig to the Well ER-8-1 site. The cost of building roads, the drill pad, and sumps is not included, and the cost of well-site support by Shaw is not included. The total construction cost for Well ER-8-1 includes all drilling costs: charges by the drilling subcontractor; charges by other support subcontractors (including compressor services, drilling fluids, bits, casing services, down-hole tools, fishing services contractor, and geophysical logging); and charges by BN for mobilizing and demobilizing equipment, partial construction of the conductor hole, cementing services, radiation technicians, inspection services, and geotechnical consultation.

The total planned cost for constructing Well ER-8-1 was $\$ 2,352,264$. The actual cost was $\$ 2,092,135$, or 11.1 percent less than the planned cost. The well was not completed as planned, so no completion materials are included in the actual cost. However, additional resources were spent on cementing and efforts to retrieve drilling equipment stuck in the borehole. Figure 8-2 presents a comparison of the planned (revised baseline task plan) and actual costs, by day, for drilling Well ER-8-1. 


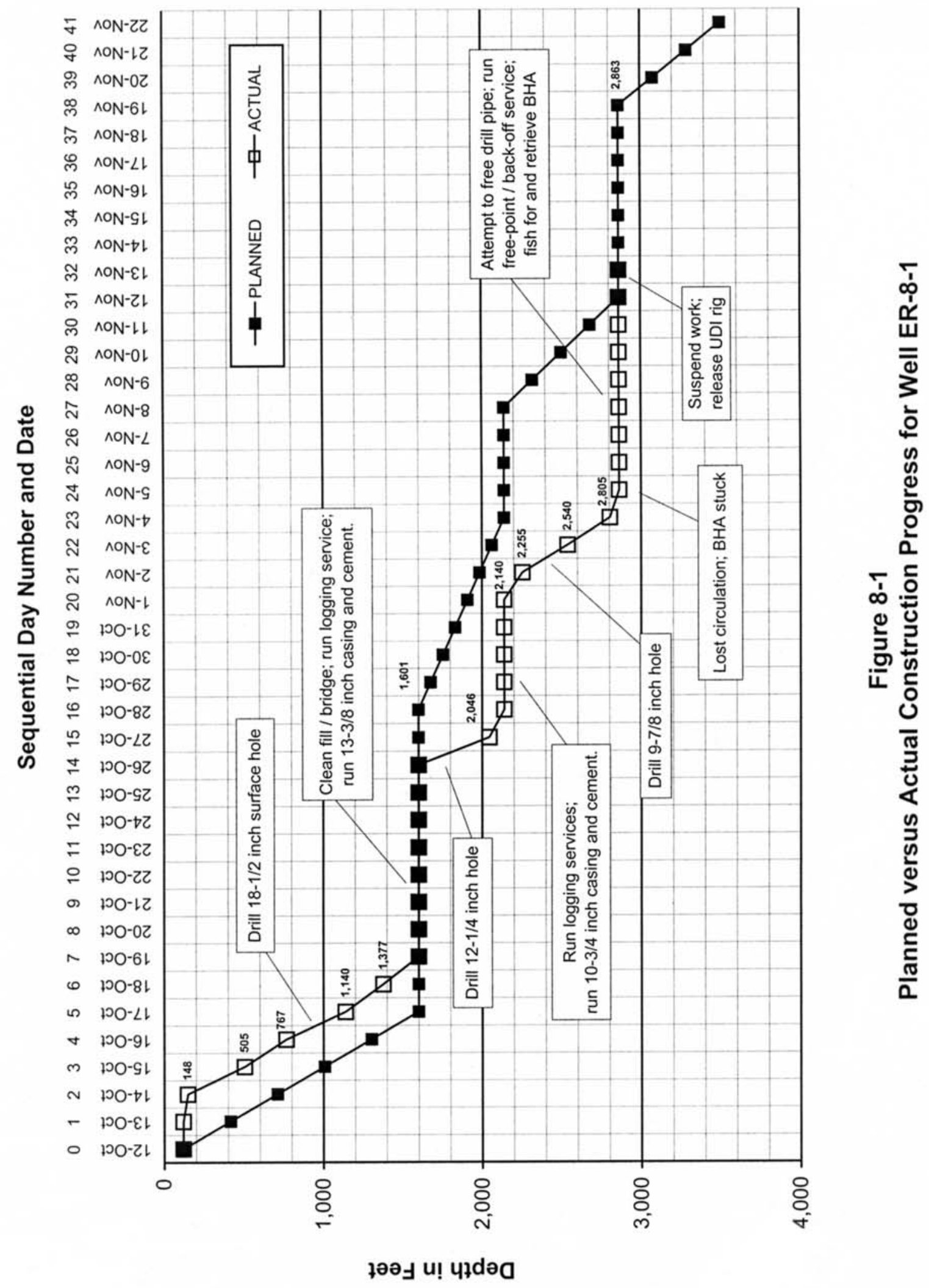




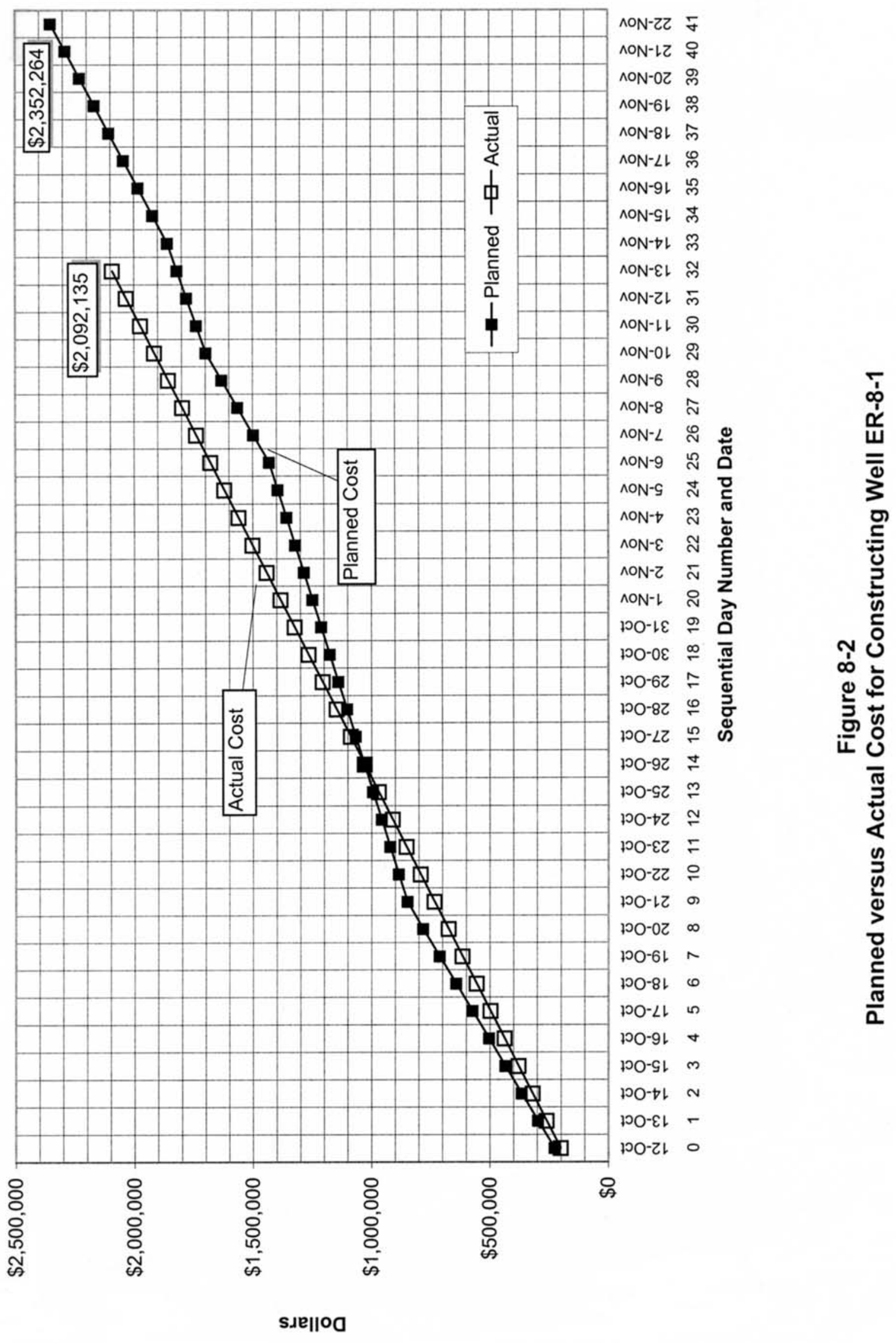


This page intentionally left blank. 


\subsection{Summary, Recommendations, and Lessons Learned}

\subsection{Summary}

Subcontractor activities at Well ER-8-1 commenced on October 8, 2002, and concluded on November 13, 2002, when the UDI rig was released. Drilling was terminated short of the planned TD

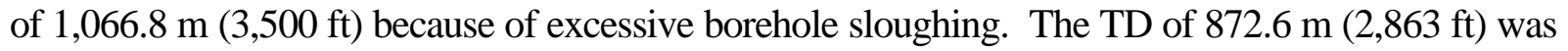
reached on November 4, 2002, when the drill string and BHA became stuck. Thirty-two working days were expended to drill the surface and main holes, conduct geophysical logging, and retrieve the BHA after being stuck for eight days. Crews worked on a 7-days-per-week, 24-hours-per-day schedule for most of the operation.

Composite drill cuttings were collected every $3 \mathrm{~m}$ (10 ft) from $36.6 \mathrm{~m}$ (120 ft) to TD. Twenty-one rotary sidewall core samples were collected in the interval 359.7 to $573.0 \mathrm{~m}$ (1,180 to 1,880 ft). Geophysical logging was conducted in the upper part of the borehole before installation of the surface casing, and in the middle part of the hole before installation of the intermediate casing string. Most of these logs were used to verify the geology and determine the hydrologic characteristics of the rocks. The interval 579.1 to $872.6 \mathrm{~m}$ (1,900 to $2,863 \mathrm{ft})$ was not logged due to the accumulation of fill. The last tag of the bottom of the borehole on April 25, 2003, indicated that $298.1 \mathrm{~m}$ (978 ft) had accumulated. The tagged depth was $629.4 \mathrm{~m}(2,065 \mathrm{ft})$.

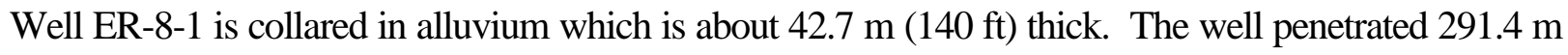
$(956 \mathrm{ft})$ of Tertiary-age tuffs, $204.8 \mathrm{~m}$ (672 ft) of Paleozoic-age dolomite, and $333.8 \mathrm{~m}$ (1,095 ft) of Cretaceous-age granite. Encountering the granite at such a shallow depth was unexpected. A preliminary composite fluid level was measured at $556 \mathrm{~m}$ (1,824 ft) on October 29, 2002, during geophysical logging operations, while the borehole was at a depth of $652.6 \mathrm{~m}(2,141 \mathrm{ft})$. However, on April 25, 2003, no water was encountered in the borehole to the top of fill at $629.4 \mathrm{~m}(2,065 \mathrm{ft})$. No radionuclides above background were encountered in the groundwater produced from Well ER-8-1.

To date the borehole has not been completed.

\section{$9.2 \quad$ Recommendations}

Because of the low conductivity formations encountered at Well ER-8-1 it may not be possible to accomplish the planned pump installation, well development, and hydrologic testing. However, Well ER-8-1 should be completed with a modified well completion design. At a minimum, a slotted 
piezometer tube should be installed to provide access to the granite confining unit below the depth of $792.5 \mathrm{~m}(2,600 \mathrm{ft})$. If this were done, potentiometric water levels and water chemistry could be obtained in order to accomplish several of the important remaining objectives for this well-construction effort.

In addition, after all the planned Yucca Flat wells are drilled, geologic and hydrologic data must be evaluated and interpretations of the area hydrogeology updated and inserted into the UGTA Yucca Flat CAU-scale hydrologic model. This process, followed by analysis of the updated model, will allow more precise characterization of groundwater flow direction and velocity in the region between the nuclear testing areas of Climax Mine and Yucca Flat.

\subsection{Lessons Learned}

The efficiency of constructing wells to obtain hydrogeologic data in support of the UGTA project continues to improve as experience is gained with each new well. Sometimes difficult drilling conditions are encountered and challenges are confronted. Several new lessons were learned during the construction of Well ER-8-1, the second well in the Yucca Flat drilling initiative.

- Experiencing lost circulation while drilling with air-foam at depth with no formation water (e.g., in a dry hole as at Well ER-8-1) can present serious problems. The resulting sudden collapse of drill cuttings in the borehole around the BHA can tightly stick the drill pipe and BHA.

- A float valve high in the drill string will prevent wireline string shots and free-point tools from passing. At Well ER-8-1, pumping fluid down the stuck drill pipe permitted some tools to pass through the flapper within the valve. However, the flapper within the float valve finally had to be removed with a wireline junk shot.

- $\quad$ After the drill string and BHA became stuck at Well ER-8-1, it was discovered that the standard equipment (jars) available on site for trying to loosen down-hole equipment were inoperable. All equipment, especially down-hole components, must be checked for operation periodically.

- Aeromagnetic data of the type used to develop the expected geology for this site, are not necessarily adequate for predicting depth to granite in the subsurface of northern Yucca Flat.

- Useful hydrogeologic information can still be acquired at well locations where pre-drill predictions are not very accurate, and a different hydrogeologic setting is found.

- Useful hydrologic information can be acquired at well locations where rocks of very low hydraulic conductivity are encountered. 


\subsection{References}

Barnes, H., F. N. Houser, and F. G. Pool, 1963. Geologic Map of the Oak Spring Quadrangle, Nye County, Nevada. U.S. Geological Survey Geologic Quadrangle Map 214, scale 1:24,000. Washington, DC.

Bechtel Nevada, 2001. Underground Testing Area (UGTA) Project Health and Safety Plan, January, 2001. Las Vegas, NV.

Bechtel Nevada, 2002. Plan for Main-Hole Drilling and Completion of Underground Test Area (UGTA) Investigation Well ER-8-1 - Original. Field Activity Work Plan Number D-010-002.03. Las Vegas, NV.

Blouin, S. E., L. S. Costin, and K. H. Wohletz, 2003. "Geotechnical Site Characteristics for HARD HAT and PILE DRIVER.” in: Hard Rock Database Review Final Report, and Proceedings of the HRDR Workshop, 28 October - 1 November, 2002, Defense Nuclear Weapons School, Kirtland AFB, NM. Defense Threat Reduction Agency Report DTRIAC-SR-03-001-V1, Ft. Belvoir, VA.

BN, see Bechtel Nevada.

Byers, F. M., Jr., W. J. Carr, P. P. Orkild, W. D. Quinlivan, and K. A. Sargent, 1976. Volcanic Suites and Related Cauldrons of the Timber Mountain-Oasis Valley Caldera Complex, Southern Nevada, U.S. Geological Survey Professional Paper 919.

Cole, J. C., 1997. Major Structural Controls on the Distribution of Pre-Tertiary Rocks, Nevada Test site Vicinity, Southern Nevada. U.S. Geological Survey Open-File Report 97-533, scale 1:100,000, 19 pp. Denver CO.

Cole, J. C., and P. H. Cashman, 1998. Structural Relationships of Pre-Tertiary Rocks in the Nevada Test Site Region, Southern Nevada. U.S. Geological Survey Professional Paper 1607.

Cole, J. C., A. G. Harris, and R. R, Wahl, 1997. Subcrop Geologic Map of Pre-Tertiary Rocks in the Yucca Flat and Northern Frenchman Flat Areas, Nevada Test Site, Southern Nevada. U.S. Geological Survey Open-File Report 97-678, scale 1:48,000, Denver, CO.

DOE/NV, see U.S. Department of Energy.

Federal Facilities Agreement Consent Order, 1996, as amended. Agreed to by the U.S. Department of Energy, the Department of Defense, and the State of Nevada. Las Vegas, NV.

Ferguson, J. F., A. H. Cogbill, and R. G. Warren, 1994. A Geophysical-Geological Transect of the Silent Canyon Caldera Complex, Pahute Mesa, Nevada. Journal of Geophysical Research, v. 99, n. 33, pp. 4323-4339. Washington, DC. 
FFACO. See Federal Facilities Agreement Consent Order.

Gonzales, J. L., S. L. Drellack, and M. J. Townsend, 1998. Written communication prepared for DOE/NV, Subject: "Descriptive Narrative for the Hydrogeologic Model at the Yucca Flat Corrective Action Unit.” An interim report. Bechtel Nevada, Las Vegas, NV.

Gonzales, J. L., and S. L. Drellack. 1999, Written communication prepared for DOE/NV, Subject: "Addendum to the Descriptive Narrative for the Hydrogeologic Model of the Yucca Flat Corrective Action Unit: Northern Extension.” Bechtel Nevada, Las Vegas, NV.

Hale, G. S., D. A. Trudeau, and C. S. Savard, 1995. Water-Level Data from Wells and Test Holes Through 1991, and Potentiometric Contours as of 1991 for Yucca Flat, Nevada Test Site, Nye County, Nevada. U.S. Geological Survey Water-Resources Investigations Report 95-4177. Denver, CO.

Houser, F. N. and F. G. Poole, 1960. "Preliminary Geologic Map of the Climax Stock and Vicinity Nye County, Nevada.” U.S. Geological Survey Miscellaneous Geologic Investigations Map I-328. Denver Colorado.

IT, see IT Corporation.

IT Corporation, 1996. Potentiometric Data Task Documentation Package (Phase I, Data Analysis Documentation, Volume II), ITLV/10972-181. Las Vegas, NV.

IT Corporation, 2002. Yucca Flat Hydrogeologic Investigation Wells Drilling and Completion Criteria, ITLV/13052-164. Las Vegas, NV.

Jachens, R. 1999, Written communication to S. L. Drellack, Bechtel Nevada. Subject: "Climax and Gold Meadows Stocks." U.S. Geological Survey, Menlo Park, CA.

Laczniak, R. J., J. C. Cole, D. A. Sawyer, and D. A. Trudeau, 1996. Summary of Hydrogeologic Controls on the Movement of Groundwater at the Nevada Test Site, Nye County, Nevada. U.S. Geological Survey Water-Resources Investigations Report 96-4109. Carson City, NV.

Maldonado, F., 1977. Summary of the Geology and Physical Properties of the Climax Stock, Nevada Test Site. U.S. Geological Survey Open-File Report 77-356. Washington, D.C.

Murray, W. A., 1981. Geohydrology of the Climax Stock Granite and Surrounding Rock Formations, NTS. Report UCRL-53138. Lawrence Livermore National Laboratories, Livermore CA.

Naiser, C. W., and F. Maldonado, 1981. Fission-track Dating of the Climax and Gold Meadows Stocks, Nye County, Nevada. U.S. Geological Survey Professional Paper 1199-E, 45-47. 
Nevada Bureau of Mines and Geology, 1997. County Digital Geologic Mapping Project - Final Report. Open-File Report 97-1, scale 1:250,000.

Orkild, P. P., D. R. Townsend, M. J. Baldwin, D. L. Healey, G. D. Bath, C. E. Jahren, and J. G. Rosenbaum, 1983. Geologic and Geophysical Investigations of Climax Stock Intrusive, Nevada. U.S. Geological Survey Open-File Report 83-377, 82 pp, 2 maps.

Phelps, G. A., E. H. McKee, D. Sweetkind and V. E. Langenheim, 1999. Preliminary Model of the Pre-Tertiary Basement Rocks Beneath Yucca Flat, Nevada Test Site, Nevada, Based on Analysis of Gravity and Magnetic Data. U.S. Geological Survey Open-File Report 00-0134.

Shaw, see Shaw Environmental, Inc.

Shaw Environmental, Inc., 2003. Written communication prepared for NNSA/NSO. Subject: "Yucca Flat ER-8-1 Well Data Report," May 2003. Las Vegas, NV.

Slate, J. L., M. E. Berry, P. D., Rowley, C. J. Fridrich, K. S. Morgan, J. B. Workman, O. D. Young, G. L. Dixon, V. S. Williams, E. H. McKee, D. A. Ponce, T. G. Hildenbrand, WC Swadley, S. C. Lundstrom, E. B. Ekren, R. G. Warren, J. C. Cole, R. J. Fleck, M. A. Lanphere, D. A. Sawyer, S. A. Minor, D. J. Grunwald, R. J. Laczniak, C. M. Menges, J. C. Yount, and A. S. Jayko, 1999. Digital Geologic Map of the Nevada Test Site and Vicinity, Nye, Lincoln, and Clark Counties, Nevada, and Inyo County, California. U.S. Geological Survey Open-File Report 99-554-A.

U.S. Department of Energy, Nevada Operations Office, 2000a. United States Nuclear Tests, July 1945 through September 1992. DOE/NV-209, Rev. 15. Las Vegas, NV.

U.S. Department of Energy, Nevada Operations Office, 2000b. Corrective Action Investigation Plan for Corrective Action Unit 97: Yucca Flat/Climax Mine, Nevada Test Site, Nevada. DOE/NV--659. Las Vegas, NV.

U.S. Department of Energy, Nevada Operations Office, 2002a. Attachment 1, "Fluid Management Plan for the Underground Test Area Project. Rev. 3,” DOE/NV--370. Las Vegas, NV.

U.S. Department of Energy, Nevada Operations Office, 2002b. Underground Test Area (UGTA) Work Management Plan. DOE/NV--343-Rev. 2. Las Vegas, NV.

Warren, R. G., D. A. Sawyer, F. M. Byers, Jr., and G. L. Cole, 2000. A Petrographic/ Geochemical Database and Stratigraphic and Structural Framework for the Southwestern Nevada Volcanic Field. Los Alamos National Laboratory Report LA-UR-00-3791. Los Alamos, NM.

Walker, G. E., 1962. Ground Water in the Climax Stock, Nevada Test Site, Nye County, Nevada. U.S. Geological Survey Trace Element Investigation Paper TEI-813, 48 pp. Washington, DC. 
Winograd, I. J. and W. Thordarson, 1975. Hydrogeologic and Hydrochemical Framework, South-Central Great Basin, Nevada-California, with Special Reference to the Nevada Test Site. U.S. Geological Survey Professional Paper 712-C.

WoldeGabriel, Giday, S. Chipera, G. Keating, E. Kluk, S. Levy, and P. Snow, 2003. Written communication to S. L. Drellack, Bechtel Nevada. Subject: "Preliminary Geological Characterization of Well ER-8-1, Yucca Flat, Nevada Test Site.” Los Alamos National Laboratory, Los Alamos, NM.

Wycoff, R. C. Environmental Restoration Division, National Nuclear Security Administration. 2002. Letter to Paul J. Leibendorfer, Nevada Division of Environmental Protection entitled, "Well-Site Fluid Management Strategy, DOE NNSA/NV Yucca Flat Drilling Program, Nevada Test Site, Well ER-8-1," dated June 26, 2002. Las Vegas, Nevada. 


\section{Appendix A \\ Drilling Data}

A-1 Drilling Parameter Log for Well ER-8-1

A-2 Casing Data for Well ER-8-1

A-3 Well ER-8-1 Drilling Fluids and Cement Composition 


\section{Appendix A-1 \\ Drilling Parameter Log for Well ER-8-1}




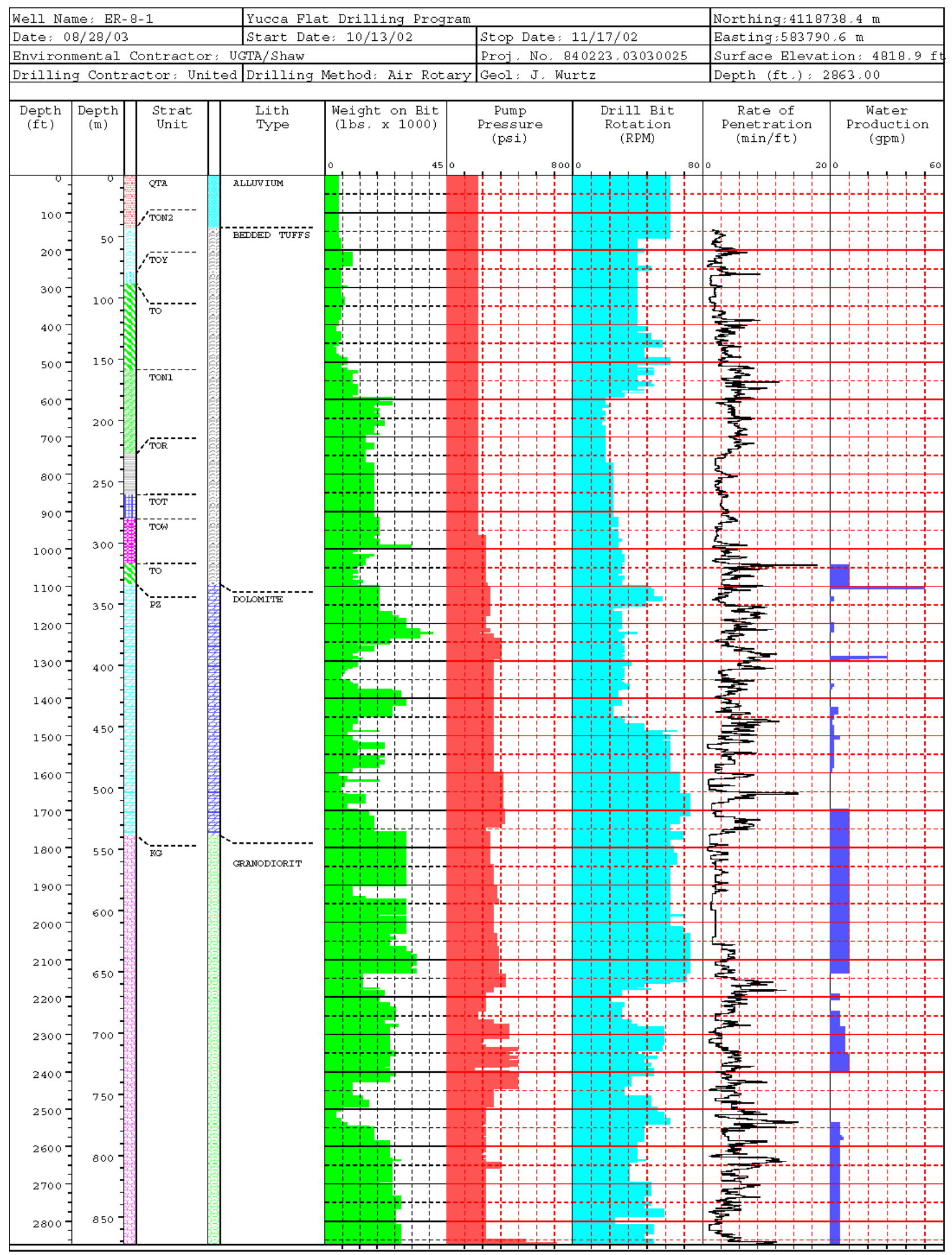


This page intentionally left blank.

A-1-2 
Appendix A-2

Casing Data for Well ER-8-1 
Table A-2

Casing Data for Well ER-8-1

\begin{tabular}{||c|c|c|c|c|c|c|c|}
\hline Casing & $\begin{array}{c}\text { Depth Interval } \\
\text { meters } \\
\text { feet) }\end{array}$ & Type & Grade & $\begin{array}{c}\text { Outside } \\
\text { Diameter } \\
\text { centimeters } \\
\text { (inches) }\end{array}$ & $\begin{array}{c}\text { Inside } \\
\text { Diameter } \\
\text { centimeters } \\
\text { (inches) }\end{array}$ & $\begin{array}{c}\text { Wall } \\
\text { Thickness } \\
\text { centimeters } \\
\text { (inches) }\end{array}$ & $\begin{array}{c}\text { Weight } \\
\text { per foot } \\
\text { (pounds) }\end{array}$ \\
\hline \hline Conductor & $\begin{array}{c}0 \text { to } 35.6 \\
\text { (0 to } 117)\end{array}$ & $\begin{array}{c}\text { Carbon Steel } \\
\text { PE Weld }\end{array}$ & Not applicable & $\begin{array}{c}76.2 \\
(30.0)\end{array}$ & $\begin{array}{c}74.295 \\
(29.0)\end{array}$ & $\begin{array}{c}1.27 \\
(0.5)\end{array}$ & 157.45 \\
\hline Surface & $\begin{array}{c}0 \text { to } 333.2 \\
(0 \text { to } 1,093.3)\end{array}$ & Carbon Steel & K55 & $\begin{array}{c}33.97 \\
(13.375)\end{array}$ & $\begin{array}{c}31.79 \\
(12.515)\end{array}$ & $\begin{array}{c}1.09 \\
(0.43)\end{array}$ & 54.5 \\
\hline Intermediate & $\begin{array}{c}0 \text { to } 577.8 \\
(0 \text { to } 1,895.8)\end{array}$ & Carbon Steel & $\begin{array}{c}\text { K55 (joints 1-9) } \\
\text { J55 (joints 10-44) }\end{array}$ & $\begin{array}{c}27.3 \\
(10.75)\end{array}$ & $\begin{array}{c}25.53 \\
(10.05)\end{array}$ & $\begin{array}{c}0.89 \\
(0.35)\end{array}$ & 40.5 \\
\hline
\end{tabular}


This page intentionally left blank.

A-2-2 
Appendix A-3

Well ER-8-1 Drilling Fluids and Cement Composition 
Table A-3-1

Well ER-8-1 Drilling Fluids

\begin{tabular}{|c|c|}
\hline Typical Air-Foam Mix ${ }^{a}$ & Typical Air-Foam/Polymer Mix ${ }^{a}$ \\
\hline $\begin{array}{c}26.5 \text { to } 75.7 \text { liters ( } 7 \text { to } 20 \text { gallons) Geofoam }{ }^{\circledR \mathrm{b}} \\
\text { and } 0.5 \text { liters of } \mathrm{LiBr} \\
\text { per } \\
7,949 \text { liters (50 barrels) water }\end{array}$ & $\begin{array}{l}\text { 34.1 to } 56.8 \text { liters ( } 9 \text { - } 15 \text { gallons) Geofoam }{ }^{\circledR} \\
\text { and } \\
7.6 \text { to } 11.4 \text { liters ( } 2 \text { - } 3 \text { gallons) LP701 }{ }^{\circledR \mathrm{b}} \\
\text { and } 0.5 \text { liters } \mathrm{LiBr} \\
\text { per } \\
7,949 \text { liters ( } 50 \text { barrels) water }\end{array}$ \\
\hline
\end{tabular}

a An air-foam ("soap") mix was used as the drilling fluid in Well ER-8-1. Various proportions of polymer were added to the air-foam to suit conditions during drilling below approximately 396.2 meters (1,300 feet).

b $\quad$ Geofoam ${ }^{\circledR}$ foaming agent and LP $701^{\circledR}$ polymer additive are products of Geo Drilling Fluids, Inc.

\section{NOTES:}

1. All water used to mix drilling fluids for Well ER-8-1 came from the fill stand near Building 6-900 supplied by Water Well C-1 at the extreme south end of Yucca Flat.

2. A concentrated solution of lithium bromide was added to all introduced fluids to make up a final concentration of 15 to 40 milligrams per liter.

3. 310,025 liters (1,950 barrels [81,900 gallons]) of 60-70 viscosity bentonite mud were pumped downhole in the effort to free stuck drill pipe.

Table A-3-2

Well ER-8-1 Cement Composition

\begin{tabular}{|c|c|c|c|}
\hline $\begin{array}{c}\text { Cement } \\
\text { Composition }\end{array}$ & $\begin{array}{c}\text { 30-inch } \\
\text { Conductor Casing }\end{array}$ & $\begin{array}{c}\text { 13d -inch } \\
\text { Surface Casing }\end{array}$ & $\begin{array}{c}103 / 4 \text {-inch } \\
\text { Intermediate Casing }\end{array}$ \\
\hline $\begin{array}{l}\text { Type II, first stage with } \\
\text { aggregate, remaining } \\
\text { stages with sand }\end{array}$ & $\begin{array}{l}0 \text { to } 36.6 \mathrm{~m}^{\mathrm{a}} \\
\left(0 \text { to } 120 \mathrm{ft}^{\mathrm{b}}\right)\end{array}$ & Not used & Not used \\
\hline Type II neat & Not used & $\begin{array}{c}\text { Annulus } \\
245.4 \text { to } 336.2 \mathrm{~m} \\
(815 \text { to } 1,103 \mathrm{ft}) \\
\text { Inside casing }^{\mathrm{c}} \\
327.3 \text { to } 338.3 \mathrm{~m} \\
(1,075 \text { to } 1,110 \mathrm{ft})\end{array}$ & $\begin{array}{l}563.9 \text { to } 579.1 \mathrm{~m} \\
(1,850 \text { to } 1,900 \mathrm{ft})\end{array}$ \\
\hline
\end{tabular}
a meter(s)
b foot (feet)
c estimated 
This page intentionally left blank.

A-3-2 


\section{Appendix B \\ Well ER-8-1 Fluid Management Data}




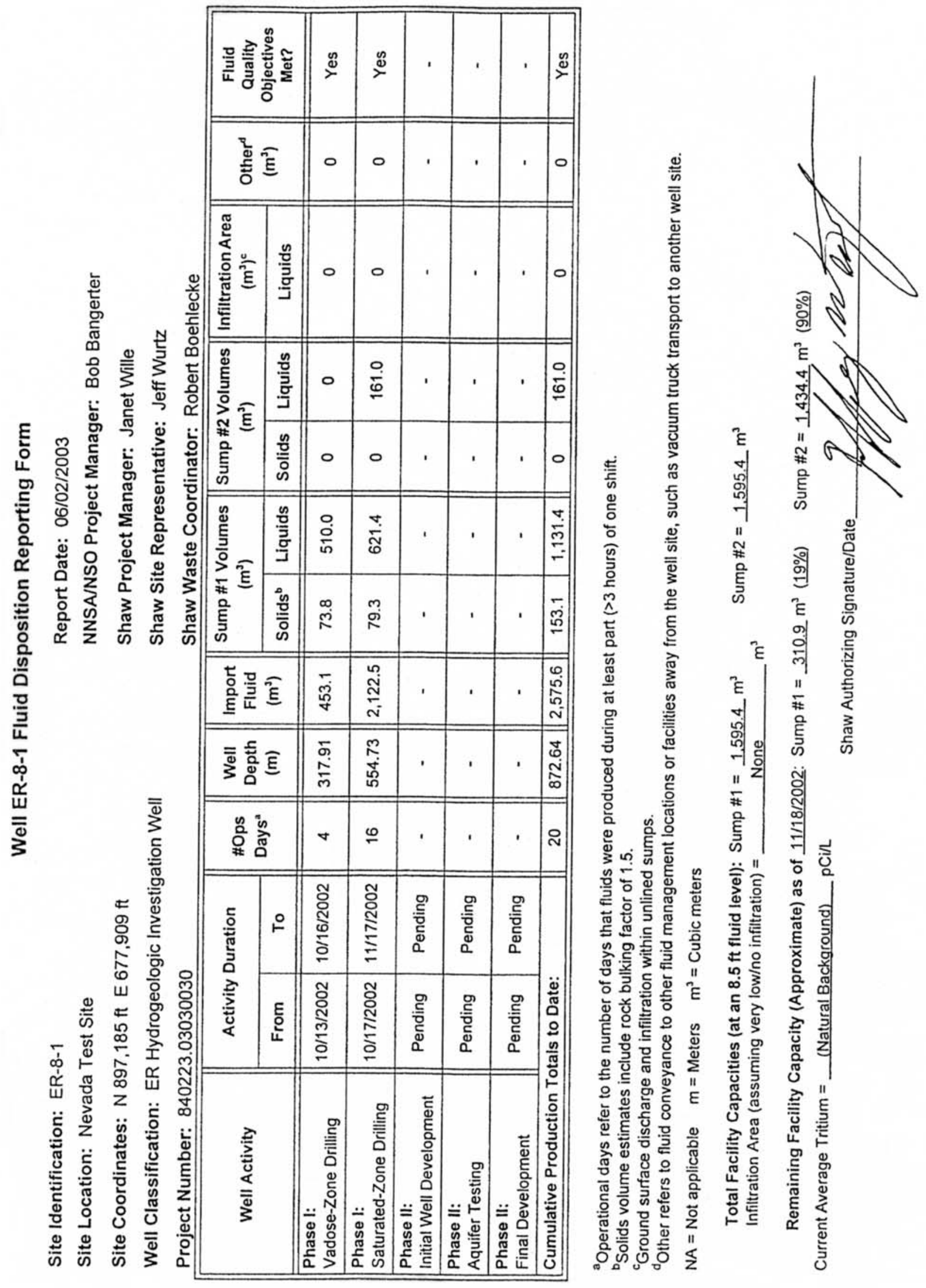


This page intentionally left blank.

B-2 
Appendix C

Detailed Lithologic Log for Well ER-8-1 
Detailed Lithologic Log for Well ER-8-1

Logged by S. L. Drellack and H. E. Huckins-Gang

Bechtel Nevada Geotechnical Sciences

June 2003

\begin{tabular}{|c|c|c|c|c|c|}
\hline $\begin{array}{l}\text { Depth } \\
\text { Interval } \\
\text { meters } \\
\text { (feet) }\end{array}$ & $\begin{array}{l}\text { Thickness } \\
\text { meters } \\
\text { (feet) }\end{array}$ & $\begin{array}{l}\text { Sample } \\
\text { Type a }^{\text {a }}\end{array}$ & $\begin{array}{l}\text { Laboratory } \\
\text { Analyses } \\
\text { (Sample depth } \\
\text { in feet) }\end{array}$ & Lithologic Description $^{c}$ & $\begin{array}{l}\text { Stratigraphic } \\
\text { Unit }^{d}\end{array}$ \\
\hline $\begin{array}{c}0-42.7 \\
(0-140)\end{array}$ & $\begin{array}{l}42.7 \\
(140)\end{array}$ & $\begin{array}{l}\text { DA1 } \\
\text { DA4 }\end{array}$ & $\begin{array}{c}P \\
130\end{array}$ & 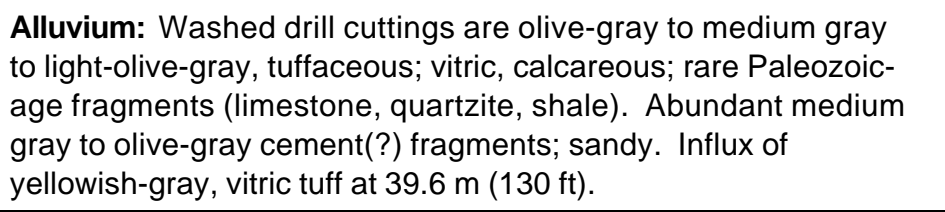 & Alluvium \\
\hline $\begin{array}{l}42.7-45.7 \\
(140-150)\end{array}$ & $\begin{array}{l}3.0 \\
(10)\end{array}$ & DA & $\begin{array}{c}P \\
140\end{array}$ & $\begin{array}{l}\text { Reworked Tuff: Grayish-orange, lesser yellowish-gray; weakly } \\
\text { calcareous; abundant pumice; minor felsic phenocrysts. }\end{array}$ & \multirow{4}{*}{$\begin{array}{l}\text { Tunnel Formation } \\
\text { bed } 2\end{array}$} \\
\hline $\begin{array}{l}45.7-51.8 \\
(150-170)\end{array}$ & $\begin{array}{l}6.1 \\
(20)\end{array}$ & DA & $\begin{array}{l}\mathrm{P}, \mathrm{XRD}, \mathrm{XRF} \\
\mathrm{Fe} \\
170\end{array}$ & $\begin{array}{l}\text { Bedded Tuff (Mostly Reworked and Lesser Air-fall Tuffs): } \\
\text { Generally grayish-orange, vitric; reworked portion is weakly } \\
\text { calcareous. Abundant yellowish-gray pumice; common (variable) } \\
\text { felsic phenocrysts; minor (though variable) lithic fragments; } \\
\text { scarce to rare mafic minerals of biotite, magnetite; } \mathrm{MnO}_{2} \\
\text { staining. }\end{array}$ & \\
\hline $\begin{array}{l}51.8-54.9 \\
(170-180)\end{array}$ & $\begin{array}{c}3.0 \\
(10)\end{array}$ & DA & None & $\begin{array}{l}\text { Air-Fall Tuff: Grayish-yellow to pale-greenish-yellow; vitric, } \\
\text { pumice rich; minor felsic phenocrysts; very scarce lithic } \\
\text { fragments and mafic minerals; common glass shards. }\end{array}$ & \\
\hline $\begin{array}{l}54.9-79.2 \\
(180-260)\end{array}$ & $\begin{array}{l}24.4 \\
(80)\end{array}$ & DA & $\begin{array}{l}P, X R D, X R F \\
\quad 200\end{array}$ & Bedded Tuff: Similar to the interval $45.7-51.8 \mathrm{~m}(150-170 \mathrm{ft})$. & \\
\hline $\begin{array}{l}79.2-88.4 \\
(260-290)\end{array}$ & $\begin{array}{l}9.1 \\
(30)\end{array}$ & DA & $\begin{array}{l}\mathrm{P}, \mathrm{XRD}, \mathrm{XRF} \\
\mathrm{Fe}, \mathrm{EM} \\
290\end{array}$ & $\begin{array}{l}\text { Bedded Tuff: Moderate-yellowish-brown; well indurated; vitric; } \\
\text { minor to common small pumice; common felsic phenocrysts; } \\
\text { scarce mafic minerals. }\end{array}$ & Yucca Flat Tuff \\
\hline
\end{tabular}




\begin{tabular}{|c|c|c|c|c|c|}
\hline $\begin{array}{l}\text { Depth } \\
\text { Interval } \\
\text { meters } \\
\text { (feet) } \\
\end{array}$ & $\begin{array}{l}\text { Thickness } \\
\text { meters } \\
\text { (feet) }\end{array}$ & $\begin{array}{l}\text { Sample } \\
\text { Type a }^{\text {a }}\end{array}$ & $\begin{array}{c}\text { Laboratory } \\
\text { Analyses } \\
\text { (Sample depth } \\
\text { in feet) } \\
\end{array}$ & Lithologic Description $^{c}$ & $\begin{array}{l}\text { Stratigraphic } \\
\text { Unit }\end{array}$ \\
\hline $\begin{array}{l}88.4-94.5 \\
(290-310)\end{array}$ & $\begin{array}{c}9.1 \\
(30)\end{array}$ & DA & None & $\begin{array}{l}\text { Air-Fall Tuff: Moderate-yellow; moderately indurated; vitric, } \\
\text { silicified in parts to possible zeolitic; vapor-phase looking } \\
\text { pumice; common felsic phenocrysts including dipyramidal } \\
\text { quartz, scarce mafic minerals of hornblende, magnetite; } \\
\text { Fe/MnO } 2 \text { stains; trace orthopyroxene; trace chalcedony. }\end{array}$ & \multirow{4}{*}{$\begin{array}{c}\text { Older tuffs, } \\
\text { undifferentiated }\end{array}$} \\
\hline $\begin{array}{l}94.5-125.0 \\
(310-410)\end{array}$ & $\begin{array}{l}30.5 \\
(100)\end{array}$ & DA & $\begin{array}{c}\mathrm{P}, \mathrm{XRD}, \mathrm{XRF}, \\
\mathrm{Fe} \\
360\end{array}$ & $\begin{array}{l}\text { Air-Fall / Bedded Tuff: Dark-yellowish orange; zeolitic; minor } \\
\text { felsic phenocrysts including dipyramidal quartz; minor lithic } \\
\text { fragments; } \mathrm{MnO}_{2} \text { stains; trace silicified, trace chalcedony } \\
\text { fragments. }\end{array}$ & \\
\hline $\begin{array}{c}125.0-140.2 \\
(410-460)\end{array}$ & $\begin{array}{l}15.2 \\
(50)\end{array}$ & DA & $\begin{array}{c}\mathrm{P}, \mathrm{XRD}, \mathrm{XRF}, \\
\text { Fe, EM } \\
450\end{array}$ & $\begin{array}{l}\text { Air-Fall Tuff (or Non-Welded Tuff): Yellowish-gray to moderate- } \\
\text { yellow; moderate induration, vitric to zeolitic; minor felsic } \\
\text { phenocrysts; scarce lithic fragments; scarce mafic minerals } \\
\text { including } \mathrm{MnO}_{2} \text { stains. }\end{array}$ & \\
\hline $\begin{array}{c}140.2-158.5 \\
(460-520)\end{array}$ & $\begin{array}{l}18.3 \\
(60)\end{array}$ & DA & None & $\begin{array}{l}\text { Air-Fall / Bedded Tuff: Grayish-orange with grayish-yellow to } \\
\text { moderate-yellow pumice; zeolitic; common small phenocrysts; } \\
\text { common small lithic fragments; scarce mafic minerals of } \\
\text { magnetite; minor } \mathrm{MnO}_{2} \text { staining. }\end{array}$ & \\
\hline $\begin{array}{c}158.5-189.0 \\
(520-620)\end{array}$ & $\begin{array}{l}30.5 \\
(100)\end{array}$ & DA & $\begin{array}{c}\mathrm{P}, \mathrm{XRD}, \mathrm{XRF}, \\
\mathrm{Fe} \\
550\end{array}$ & $\begin{array}{l}\text { Bedded Tuff: Pale-greenish-yellow to grayish-orange; zeolitic; } \\
\text { abundant very-pale-orange to grayish-orange small pumice, } \\
\text { common felsic phenocrysts; scarce to minor mafic minerals of } \\
\text { biotite and magnetite. } \\
\text { Moderate-yellow, shard-rich air-fall tuff at } 167.6-170.7 \mathrm{~m} \\
(550-560 \mathrm{ft}) \text { with very scarce phenocrysts and lithic fragments. }\end{array}$ & \multirow[t]{2}{*}{$\begin{array}{c}\text { Tunnel } \\
\text { Formation, bed } 1\end{array}$} \\
\hline $\begin{array}{c}189.0-227.1 \\
(620-745)\end{array}$ & $\begin{array}{l}38.1 \\
(125)\end{array}$ & DA1 & $\begin{array}{c}\mathrm{P}, \mathrm{XRD}, \mathrm{XRF}, \\
\text { Fe, EM } \\
730\end{array}$ & $\begin{array}{l}\text { Air-Fall and Bedded Tuff: Pale-yellowish-brown with pale- } \\
\text { reddish-brown in parts. Common very-pale-orange to grayish- } \\
\text { yellow pumice; zeolitic; common felsic phenocrysts; minor to } \\
\text { common mafic minerals of biotite, magnetite, trace pyroxene and } \\
\text { hornblende. Minor lithic fragments. }\end{array}$ & \\
\hline
\end{tabular}




\begin{tabular}{|c|c|c|c|c|c|}
\hline $\begin{array}{l}\text { Depth } \\
\text { Interval } \\
\text { meters } \\
\text { (feet) } \\
\end{array}$ & $\begin{array}{l}\text { Thickness } \\
\text { meters } \\
\text { (feet) }\end{array}$ & $\begin{array}{l}\text { Sample } \\
\text { Type a }^{\text {a }}\end{array}$ & $\begin{array}{c}\text { Laboratory } \\
\text { Analyses } \\
\text { (Sample depth } \\
\text { in feet) } \\
\end{array}$ & Lithologic Description ${ }^{c}$ & $\underset{\text { Unit }^{\mathrm{d}}}{\text { Stratigraphic }}$ \\
\hline $\begin{array}{l}227.1-231.6 \\
(745-760)\end{array}$ & $\begin{array}{c}4.6 \\
(15)\end{array}$ & DA & $\begin{array}{l}\text { P, XRD, XRF, } \\
\text { Fe } \\
750\end{array}$ & $\begin{array}{l}\text { Bedded to Reworked Tuff: Moderate-reddish-brown; zeolitic; } \\
\text { moderate induration; variable amounts of pumice, felsic } \\
\text { phenocrysts and lithic fragment; rare mafic minerals. }\end{array}$ & \multirow[b]{2}{*}{$\begin{array}{l}\text { Redrock Valley } \\
\text { Tuff }\end{array}$} \\
\hline $\begin{array}{l}231.6-260.6 \\
(760-855)\end{array}$ & $\begin{array}{l}22.9 \\
(75)\end{array}$ & DB4 & $\begin{array}{l}\mathrm{P}, \mathrm{XRD}, \mathrm{XRF} \\
\mathrm{Fe}, \mathrm{EM} \\
810\end{array}$ & $\begin{array}{l}\text { Bedded Tuff: Mixture of light-brown to moderate-reddish-brown } \\
\text { and very-pale-orange below } 238 \mathrm{~m}(780 \mathrm{ft}) ; \text { zeolitic; variable to } \\
\text { abundant felsic phenocrysts; rare to common (variable) mafic } \\
\text { minerals; abundant larger lithic fragments of devitrified rhyolitic } \\
\text { lava. }\end{array}$ & \\
\hline $\begin{array}{c}260.6-280.4 \\
(855-920)\end{array}$ & $\begin{array}{l}19.8 \\
(65)\end{array}$ & DB4 & $\begin{array}{l}P, X R D \\
880\end{array}$ & $\begin{array}{l}\text { Bedded Tuff: Moderate-reddish-orange; zeolitic; common to } \\
\text { abundant felsic phenocrysts; common to abundant pumice; } \\
\text { minor mafic minerals of biotite and tiny magnetite. }\end{array}$ & $\begin{array}{l}\text { Tuff of Twin } \\
\text { Peaks }\end{array}$ \\
\hline $\begin{array}{c}280.4-298.7 \\
(920-980)\end{array}$ & $\begin{array}{l}18.3 \\
(60)\end{array}$ & DB4 & $\begin{array}{l}\mathrm{P}, \mathrm{XRD}, \mathrm{XRF} \\
\mathrm{Fe}, \mathrm{EM} \\
970\end{array}$ & $\begin{array}{l}\text { Bedded Tuff: Grayish-orange with pale yellowish-green pumice; } \\
\text { zeolitic; minor to common felsic phenocrysts; rare to minor mafic } \\
\text { minerals of biotite, magnetite, and hornblende. }\end{array}$ & \multirow[b]{2}{*}{$\begin{array}{l}\text { Tuff of White } \\
\text { Rock Spring }\end{array}$} \\
\hline $\begin{array}{l}298.7-317.0 \\
(980-1,040)\end{array}$ & $\begin{array}{l}18.3 \\
(60)\end{array}$ & DB1 & $\begin{array}{l}\mathrm{P}, \mathrm{XRD}, \mathrm{XRF} \\
\mathrm{Fe} \\
1,030\end{array}$ & $\begin{array}{l}\text { Bedded Tuff: Moderate-reddish-brown; similar to the interval } \\
231.6-260.6 \mathrm{~m}(760-855 \mathrm{ft}) ; \text { zeolitic to argillic. Cuttings } \\
\text { samples are enriched in lithic fragments of devitrified rhyolitic } \\
\text { lava within "meta-conglomerate" (?) interval at } 305-320 \mathrm{~m} \\
(1,000-1,505 \mathrm{ft}) \text {. }\end{array}$ & \\
\hline $\begin{array}{c}317.0-321.6 \\
(1,040-1,055)\end{array}$ & $\begin{array}{c}4.6 \\
(15)\end{array}$ & DB4 & None & $\begin{array}{l}\text { Bedded Tuff: Pale-yellowish-brown; zeolitic to argillic; minor } \\
\text { (though variable) pumice; abundant small felsic phenocrysts; rare } \\
\text { to minor mafic minerals of magnetite, biotite, and hornblende; } \\
\text { scarce lithic fragments. }\end{array}$ & \multirow[t]{2}{*}{$\begin{array}{l}\text { Older tuffs, } \\
\text { undifferentiated }\end{array}$} \\
\hline $\begin{array}{c}321.6-330.7 \\
(1,055-1,085)\end{array}$ & $\begin{array}{l}9.1 \\
(30)\end{array}$ & DB1 & None & $\begin{array}{l}\text { Bedded Tuff: Similar to the interval } 298.7-317.0 \mathrm{~m} \\
\text { (980 - 1,040 ft). }\end{array}$ & \\
\hline
\end{tabular}




\begin{tabular}{|c|c|c|c|c|c|}
\hline $\begin{array}{c}\text { Depth } \\
\text { Interval } \\
\text { meters } \\
\text { (feet) } \\
\end{array}$ & $\begin{array}{l}\text { Thickness } \\
\text { meters } \\
\text { (feet) }\end{array}$ & $\begin{array}{l}\text { Sample } \\
\text { Type a }^{\text {a }}\end{array}$ & $\begin{array}{c}\text { Laboratory } \\
\text { Analyses } \\
\text { (Sample depth } \\
\text { in feet) }\end{array}$ & Lithologic Description $^{c}$ & $\begin{array}{l}\text { Stratigraphic } \\
\text { Unit }^{d}\end{array}$ \\
\hline $\begin{array}{c}330.7-334.1 \\
(1,085-1,096)\end{array}$ & $\begin{array}{c}3.0 \\
(11)\end{array}$ & DB4 & None & $\begin{array}{l}\text { Air-Fall Tuff: Grayish-orange; zeolitic; common pumice; } \\
\text { abundant felsic phenocrysts; common mafic minerals of biotite } \\
\text { and magnetite; rare lithic fragments. }\end{array}$ & $\begin{array}{c}\text { Older tuffs, } \\
\text { undifferentiated }\end{array}$ \\
\hline $\begin{array}{c}334.1-431.3 \\
(1,096-1,415)\end{array}$ & $\begin{array}{l}97.2 \\
(319)\end{array}$ & $\begin{array}{l}\text { DB4 } \\
\text { SWC }\end{array}$ & $\begin{array}{c}\mathrm{P}, \mathrm{XRD}, \mathrm{XRF}, \\
\mathrm{Fe} \\
1,140 \\
1,270 \\
1,330\end{array}$ & $\begin{array}{l}\text { Dolomite: Medium-light-gray to very-light gray; medium } \\
\text { crystalline; some fragments with small } \mathrm{MnO}_{2} \text { spots/stains. } \\
\text { Dark-yellowish-orange and moderate reddish-orange fracture } \\
\text { staining increasingly common below } 371.9 \mathrm{~m}(1,220 \mathrm{ft}) \text {. Cuttings } \\
\text { samples from below } 353.6 \mathrm{~m}(1,150 \mathrm{ft}) \text { are contaminated with tuff } \\
\text { from the interval } 321.6-334.1 \mathrm{~m}(1,055-1,096 \mathrm{ft}) \text {. }\end{array}$ & \\
\hline $\begin{array}{c}431.3-538.5 \\
(1,415-1,768)\end{array}$ & $\begin{array}{l}107.6 \\
(353)\end{array}$ & $\begin{array}{l}\text { DA } \\
\text { SWC }\end{array}$ & None & $\begin{array}{l}\text { Dolomite with Altered Intrusive Dikes: Yellowish-gray (due to } \\
\text { staining) to very-light-gray, similar to above, accept staining } \\
\text { more prevalent. Intrusive material is dark-yellowish-orange fine- } \\
\text { grained calcareous, altered, with occasional breccia fragments of } \\
\text { very-light-gray dolomite. Blotchy to dendritic } \mathrm{MnO}_{2} \text { common. } \\
\text { Intrusive and/or highly altered zones correspond to higher natural } \\
\text { gamma readings on the Spectral Gamma-Ray Log (e.g., at } \\
432.8 \text {, and } 446.4-454.2 \text {, and } 492.3-502.9 \mathrm{~m}[1,420 \text {, } \\
1,465-1,490 \text { and } 1,615-1,650 \mathrm{ft}]) \text {. Bright-blue and greenish- } \\
\text { blue chrysocolla and altered dolomite noted at } 438.9 \mathrm{~m}(1,440 \mathrm{ft}) \text {. } \\
\text { Some brecciated (cataclastic?) and/or hydrothermally altered. } \\
\text { Sample at } 493.8 \mathrm{~m}(1,620 \mathrm{ft} \text { ) is contaminated with up-hole } \\
\text { material. Slickensides observed in the } 539.5 \mathrm{~m}(1,770 \mathrm{ft}) \\
\text { cuttings sample box and in the } 532.2 \mathrm{~m}(1746 \mathrm{ft}) \text { sidewall core. }\end{array}$ & $\begin{array}{l}\text { Paleozoic } \\
\text { carbonate rocks, } \\
\text { undifferentiated }\end{array}$ \\
\hline
\end{tabular}




\begin{tabular}{|c|c|c|c|c|c|}
\hline $\begin{array}{c}\text { Depth } \\
\text { Interval } \\
\text { meters } \\
\text { (feet) } \\
\end{array}$ & $\begin{array}{l}\text { Thickness } \\
\text { meters } \\
\text { (feet) }\end{array}$ & $\begin{array}{l}\text { Sample } \\
\text { Type }^{\text {a }}\end{array}$ & $\begin{array}{c}\text { Laboratory } \\
\text { Analyses } \\
\text { (Sample depth } \\
\text { in feet) }\end{array}$ & Lithologic Description $^{c}$ & $\begin{array}{c}\text { Stratigraphic } \\
\text { Unit }^{d}\end{array}$ \\
\hline $\begin{array}{c}538.9-872.6 \\
(1,768-2,863) \\
\text { TD }\end{array}$ & $\begin{array}{c}333.8 \\
(1,095)\end{array}$ & $\begin{array}{l}\text { DA } \\
\text { DB4 } \\
\text { SWC }\end{array}$ & $\begin{array}{c}P, X R D, X R F, \\
F e \\
1,798 ; 1,819 \\
1,829 ; 1,850 \\
1,860 ; 1,880\end{array}$ & 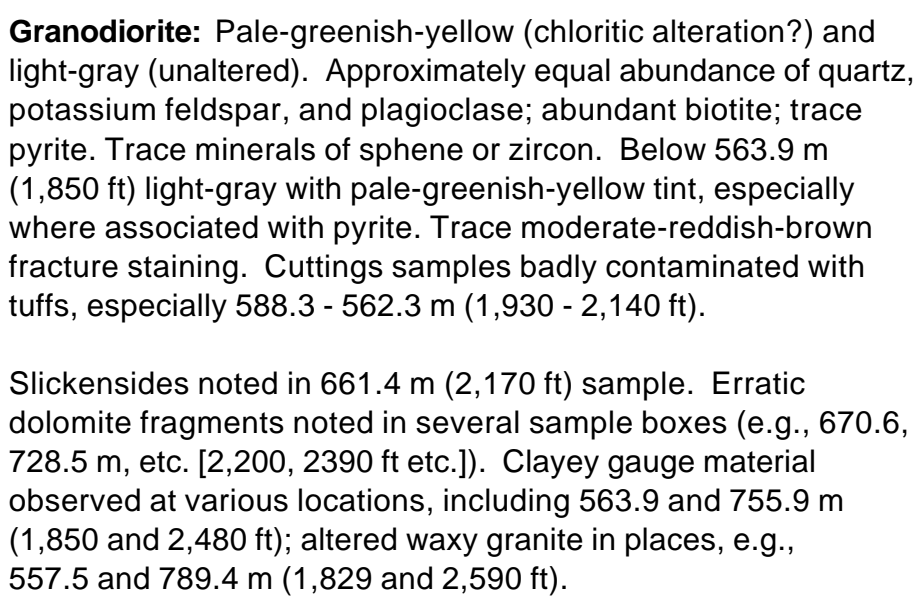 & Granitic rocks \\
\hline
\end{tabular}

1. $\mathbf{D A}=$ drill cuttings that represent lithologic character of interval; $\mathbf{D B} 1=$ drill cuttings enriched in hard components; $\mathbf{D B} 4=$ cuttings that are intimate mixtures of units; generally less than $50 \%$ of drill cuttings represent lithologic character of interval; SWC $=$ Sidewall core.

2. $\mathbf{P}=$ petrographic microscope $; \mathbf{T S}=$ polished thin section; $\mathbf{X R D}=x$-ray diffraction; $\mathbf{X R F}=x$-ray fluorescence; $\mathbf{F e}=\mathrm{Fe} 2+/ F e 3+; \mathbf{E M}=E$ Electron microprobe. See Table 3-1 of this report for additional information.

3. Descriptions are based mainly on visual examination of lithologic samples using a 10x- to 40x-zoom binocular microscope, and incorporating observations from geophysical logs and results of laboratory analyses. Colors describe wet sample color.

Abundances for felsic phenocrysts, pumice fragments, and lithic fragments: trace = only one or two individuals observed; rare $=\leq 1 \%$; minor $=5 \%$; common $=10 \%$; abundant $=15 \%$; very abundant $\geq 20 \%$.

Abundances for mafic minerals: trace $=$ only one or two individuals observed; rare $=\leq 0.05 \%$; minor $=0.2 \%$; common $=0.5 \%$; abundant $=1 \%$; very abundant $=\geq 2 \%$.

4. Stratigraphic assignments for the Tertiary-age tuffs are based on geochemical and mineralogical analyses by WoldeGabriel et al. (2003). 
This page intentionally left blank.

C-6 


\section{Appendix D \\ Geophysical Logs Run in Well ER-8-1}


Appendix D contains unprocessed data presentations of selected geophysical logs run in Well ER-8-1.

Table D-1 summarizes the logs presented. See Table 3-3 for more information.

Table D-1

Well ER-8-1 Geophysical Logs Presented

\begin{tabular}{|c|c|c|c|c|}
\hline Log Type & $\begin{array}{c}\text { Run } \\
\text { Number }\end{array}$ & Date & meters $^{\log }$ & feet \\
\hline Caliper & $\begin{array}{l}\text { CA6-1 } \\
\text { CA6-2 }\end{array}$ & $\begin{array}{l}10 / 29 / 2002 \\
10 / 29 / 2002\end{array}$ & $\begin{array}{r}15.2-328.3 \\
274.3-581.9\end{array}$ & $\begin{array}{c}50-1,077 \\
900-1,909\end{array}$ \\
\hline Epithermal Neutron & $\begin{array}{l}\text { DSEN-1 } \\
\text { DSEN-2 }\end{array}$ & $\begin{array}{l}10 / 22 / 2002 \\
10 / 29 / 2002\end{array}$ & $\begin{array}{c}0-329.2 \\
274.3-580.3\end{array}$ & $\begin{array}{c}0-1,080 \\
900-1,904\end{array}$ \\
\hline Density & $\begin{array}{l}\text { SDL-1 } \\
\text { SDL-2 } \\
\end{array}$ & $\begin{array}{l}10 / 22 / 2002 \\
10 / 29 / 2002\end{array}$ & $\begin{array}{c}0-329.2 \\
274.3-580.3\end{array}$ & $\begin{array}{c}0-1,080 \\
900-1,904\end{array}$ \\
\hline Induction (resistivity) & $\begin{array}{l}\mathrm{HRI}-1 \\
\mathrm{HRI}-1\end{array}$ & $\begin{array}{l}10 / 22 / 2002 \\
10 / 29 / 2002\end{array}$ & $\begin{array}{c}0-332.5 \\
274.3-580.3\end{array}$ & $\begin{array}{c}0-1,091 \\
900-1,904\end{array}$ \\
\hline Gamma Ray & $\begin{array}{l}\text { GR-3 } \\
\text { GR-4 }\end{array}$ & $\begin{array}{l}10 / 21 / 2002 \\
10 / 29 / 2002 \\
\end{array}$ & $\begin{array}{c}0-332.5 \\
274.3-581.3 \\
\end{array}$ & $\begin{array}{c}0-1,091 \\
900-1,907 \\
\end{array}$ \\
\hline $\begin{array}{c}\text { Spectral Gamma Ray } \\
\text { (potassium, thorium, uranium) }\end{array}$ & $\begin{array}{l}\text { SGR-1 } \\
\text { SGR-2 }\end{array}$ & $\begin{array}{l}10 / 19 / 2002 \\
10 / 29 / 2002 \\
\end{array}$ & $\begin{array}{r}15.2-328.3 \\
274.3-581.9 \\
\end{array}$ & $\begin{array}{r}50-1,077 \\
900-1,909 \\
\end{array}$ \\
\hline
\end{tabular}




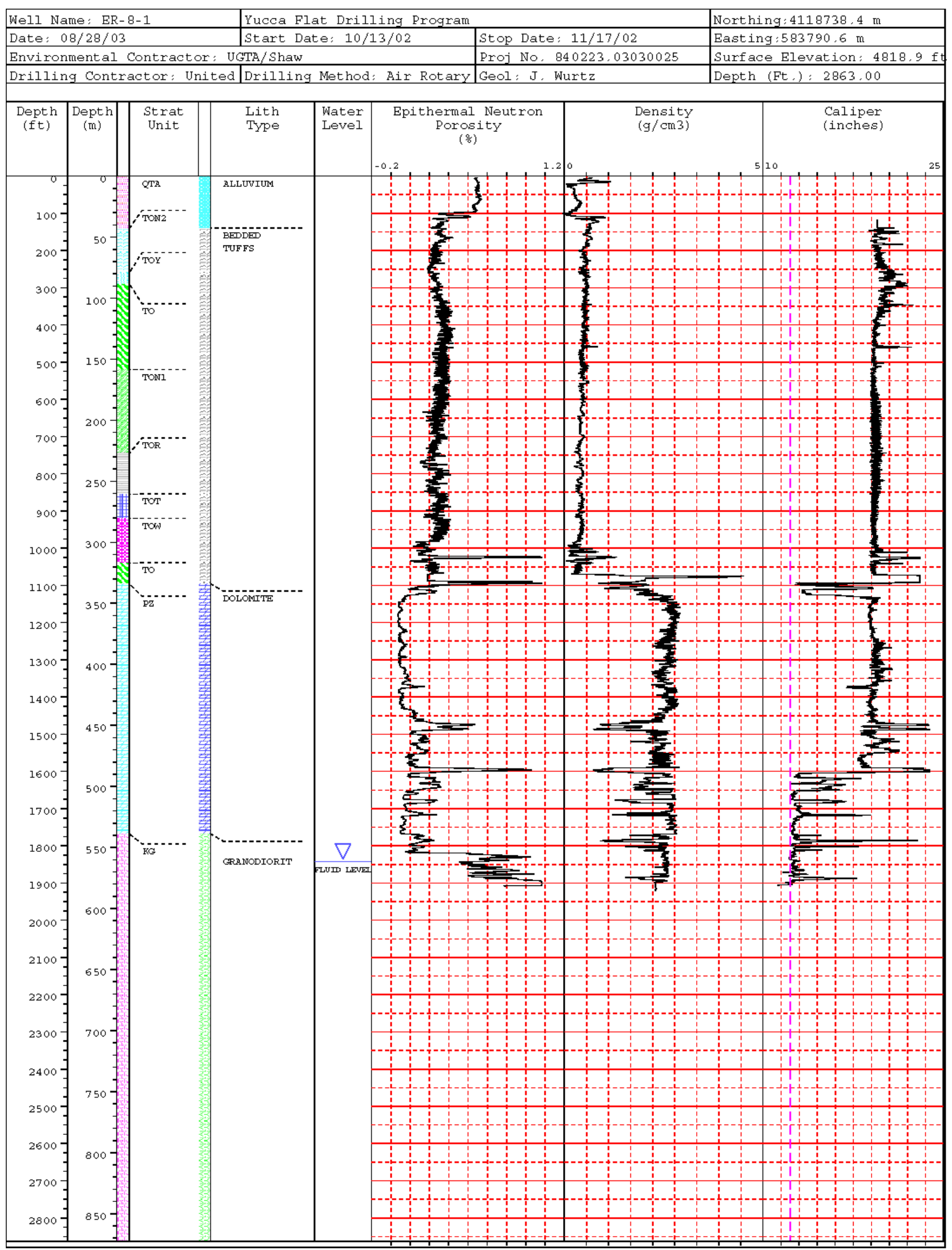




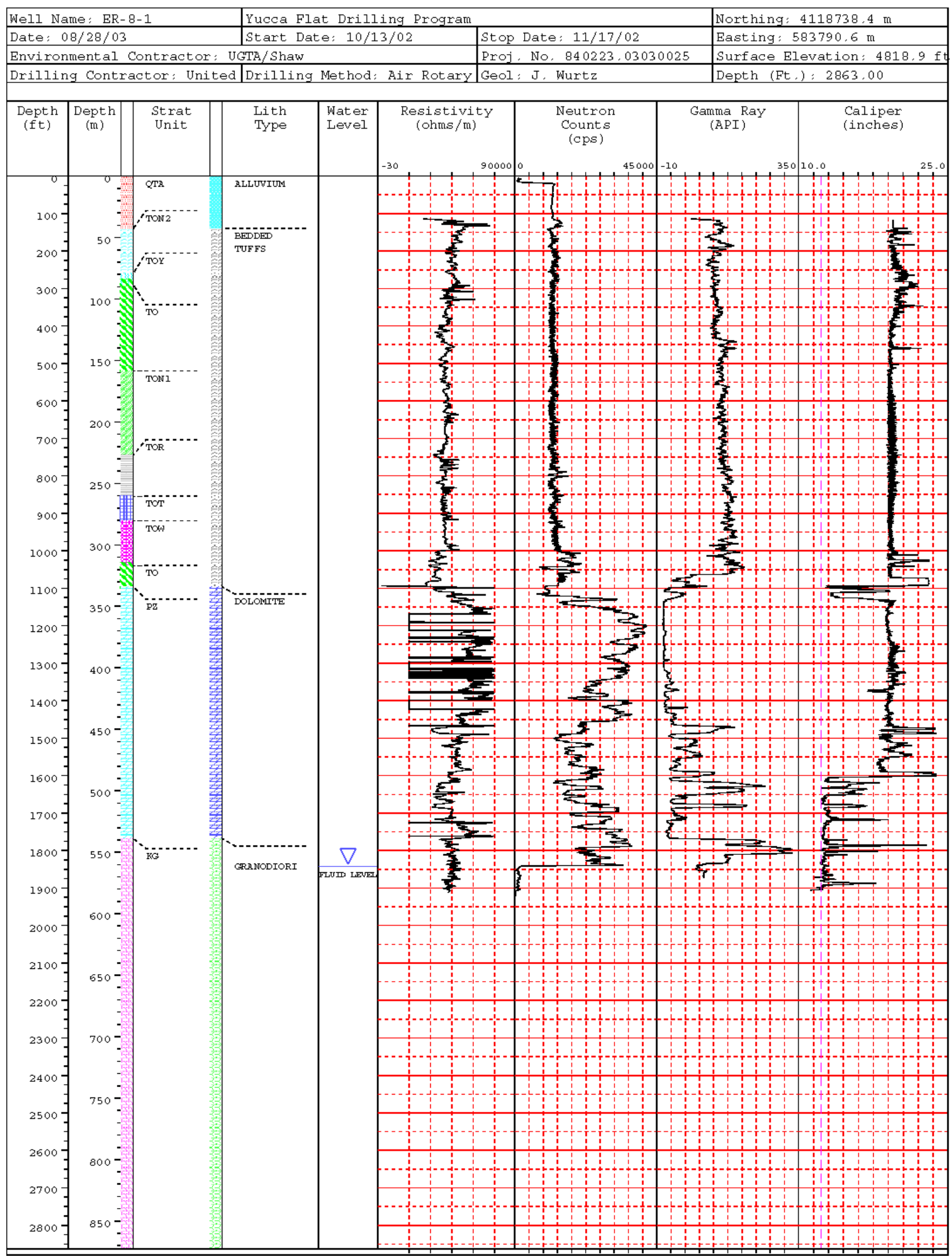




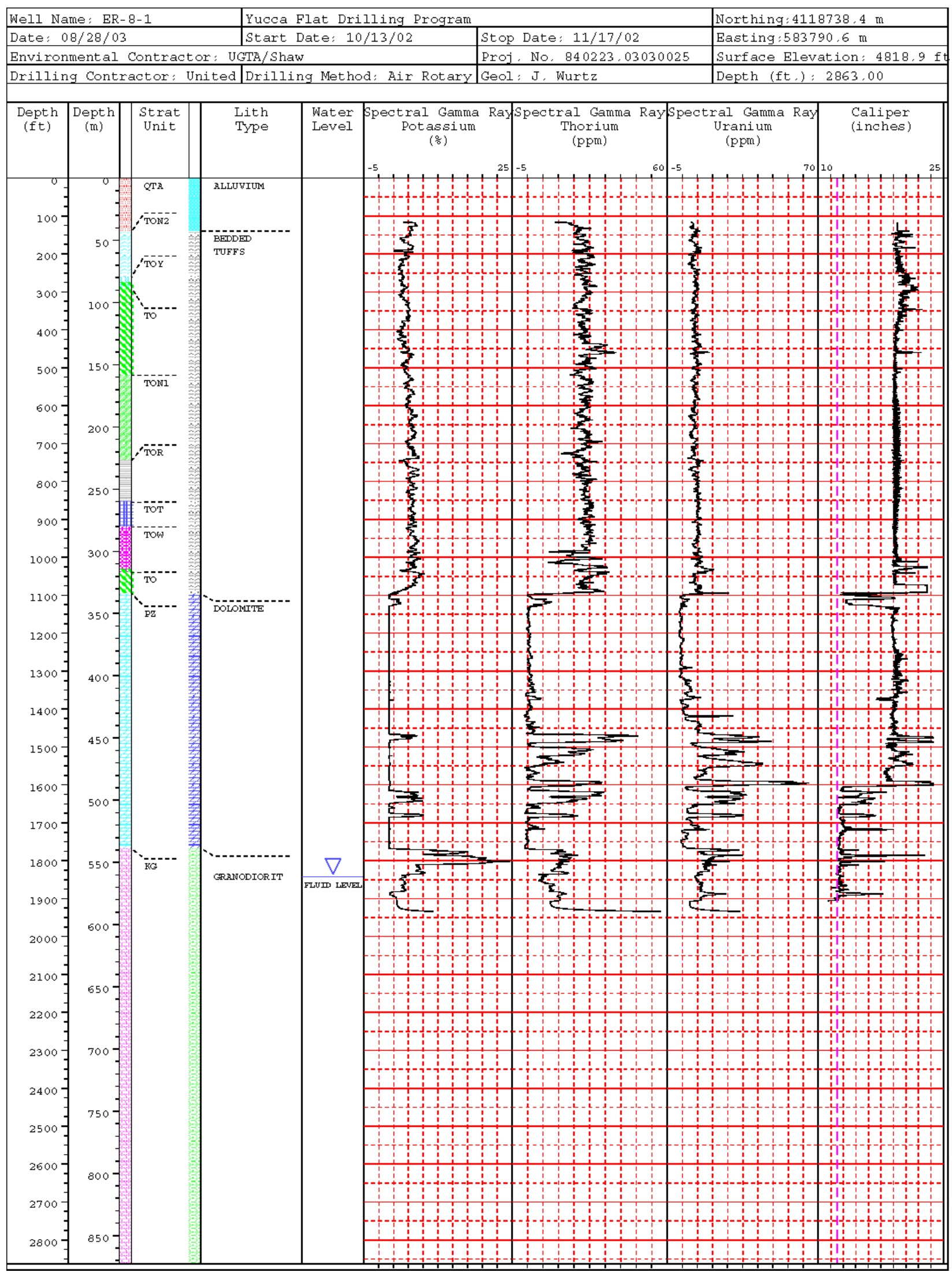




\section{Distribution List}

$\underline{\text { Copies }}$

R. M. Bangerter

2

U.S. Department of Energy

National Nuclear Security Administration

Nevada Site Office

Environmental Restoration Division

P.O. Box 98518, M/S 505

Las Vegas, NV 89193-8518

U.S. Department of Energy

1

National Nuclear Security Administration

Nevada Site Office

Technical Library

P.O. Box 98518, M/S 505

Las Vegas, NV 89193-8518

U.S. Department of Energy

1

National Nuclear Security Administration

Nevada Site Office

Nuclear Testing Archive

Public Reading Facility

P.O. Box 98518, M/S 400

Las Vegas, NV 89193-8518

U.S. Department of Energy

1 (electronic)

Office of Scientific and Technical Information

Post Office Box 62

Oak Ridge, Tennessee 37831-0062

K. A. Hoar, Director

U.S. Department of Energy

National Nuclear Security Administration

Nevada Site Office

Environment, Safety and Health Division

P.O. Box 98518, M/S 505

Las Vegas, NV 89193-8518

P. K. Ortego

Bechtel Nevada

P.O. Box 98521, M/S NLV082

Las Vegas, NV 89193-8521 


\section{Distribution List (continued)}

\section{$\underline{\text { Copies }}$}

John McCord

UGTA Project Manager

Stoller-Navarro Joint Venture

7710 West Cheyenne Ave.

Building 3

Las Vegas, NV 89129

Stoller-Navarro Library

Stoller-Navarro Joint Venture

7710 West Cheyenne Ave.

Building 3

Las Vegas, NV 89129

W. L. Hawkins

Los Alamos National Laboratory

P. O. Box 1663

Los Alamos, NM 87545-1663

G. A. Pawloski

Lawrence Livermore National Laboratory

P. O. Box 808

Livermore, CA 94551-0808

T. P. Rose

Lawrence Livermore National Laboratory

P. O. Box 808

Livermore, CA 94551-0808

B. K. Thompson

DOE/USGS Cooperative Program Manager

U.S. Geological Survey

Water Resources Division

6770 South Paradise Road

Las Vegas, NV 89119-3721

C. E. Russell

Desert Research Institute

755 East Flamingo Road

P.O. Box 19040

Las Vegas, NV 89119-7363 